\title{
الهوية الإسلامية
}

\section{رؤية تأصيلية في ضو ء التحديات المعاصرة}

$$
\begin{aligned}
& \text { تأليف } \\
& \text { الدكتور / حسن عبد الغني حسن حسان }
\end{aligned}
$$



$$
\begin{aligned}
& \text { كلية الدعوة الإسلامية بالقاهرة الإنادية المباعة } \\
& \text { جامعة الأز هر الأسرة }
\end{aligned}
$$






\section{الهوية الإسلامية (روية تأصيلية في ضوء التحديات المعاصرة)}

$$
\text { ملخص البحث: }
$$

يتناول البحث التعريف بحقيقة الهوية الإسلامية وأهميتها، وخصائصها.ثم ينتقل لبيان أهم التحديات المعاصرة التي تواجه الهوية الإسلامية ومنها العولمة وأثرها على الهوية الإسلامية، كما تناول الغزو الفكري وأثثه على الهوية الإسلامية.

ثم قلَّم البحث مسئولية الأمة في الحفاظ على الهوية الإسلامية في ظل التحديات المعاصرة، فذكر الدور الذي يجب على المؤسسات الدعوية والاجتماعية أن تقوم به؛ لترسيخ الهوية في قلوب المسلمين، حيث تتوزع هذه المسؤوليات على الفئات المتنوعة في المجتمع ومنها العلماء والدعاة، والأسرة وما لهم من مكانة في تكوين وصيانة هذه الهوية الإسلامية، وكذا المؤسسات التربوية وجهودها في الحفاظ على الهوية الإسلامية لدى الأجيال المعاصرة، ومسئولية الحكام والولاة في الحفاظ على هوية الأمة، ووسائل الإعلام في نشر الوعي والحفاظ على الهوية.

ثم تتاول البحث واقع الهوية الإسلامية في ضوء التحديات المعاصرة، وأساليب طمس الهوية الإسلامية، كما استفاض في بيان ثمار تمسك العالم الإسلامي بالهوية في ضوء التحديات المعاصرة.


الهوية-الإسلامية-رؤية- تأصيلية- التحديات- المعاصرة 
الهوية الإسلامية (روية تأصيلية في ضوء التحديات المعاصرة)

المقـدمة




If $\rightarrow$ Q Q










العالمين .

$$
\text { أما بعد ؛؛؛؛؛؛؛؛؛ }
$$

فإن هويـة المسلمين أصبحت في خطر يسترع انتباه العلماء والمفكرين والأمـة الإسلامية،

كما أن الهويـة الإسـلامية التي تمثل كيان الأمـة تعـاني من تحديات جسيمة








لقد حافظ الإسـلام على هويـة المسلمين لتميزهم عن غيرهم من الأمم، قال






1 - الأنعام الآية : سما. 
الهوية الإسلامية (روية تأصيلية في ضوء التحديات المعاصرة)



$\rightarrow \Omega \square \pi G \&$ \&

(')

فالهوية لها أهمية عظمى في حياة المسلمين، لأنها تجعل للفرد قيمة،

وتحفظ للمجتمع كيانه، كما تحرص على تماسك الأمة وبقائها، ولا أدل على ذلك كما لهاء


بها، لأن فيها معنى حياتها، وتحقيق وجودها في واقع الحياة.




وبذلك تضيع الغالي والنفيس الذي منحه الله تعالى لها، وتفرط في الأمانة التي كلفها


التحديات، فإنها مازالت تتادي على المسلمين بالرجوع إليها حفاظا على كيانهم




كل العجب أن الأمة الإسلامية تترك واجبها في دعوة غير المسلمين إلى مبادئ


الصالح، وتأخذ من الهويات الأخرى الزائفة لتدمر الأجيال، وتفسد العقول، وتقلد غيرها




ولكن الله تعالى جعلها محفوظة برعايته ولو كره المنكرون. ومن هنا كان على الدعاة دور كبير في ظل هذه التحديات المعاصرة لترسيخ ورن التكرون 
الهوية الإسلامية (روية تأصيلية في ضوء التحديات المعاصرة)

الهوية في قلوب المسلمين، كما أن للأسرة دورها وللحكام دورهم، ولوسائل الإعلام وللثقافة













لقد كان من أهم الأسباب التي دفعتني لاختيار هذا الموضوع ما يلي:

$$
\text { (1) التحديات التي تواجهها الهوية الإسلامية في الداخل والخارج. }
$$



وحقيقتها، وما تمثله بالنسبة لشعوب العالم لإثبات وجودها وكيانها.



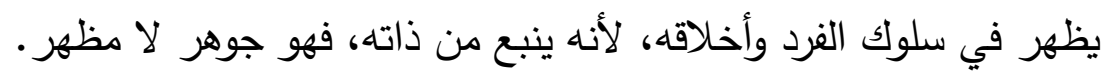









(1) (1ق ناقوس الخطر من تميع هوية المسلمين تمهيدا لمحوها في العصر

الحاضر، مع تشخيص الداء وتقديم العلاج في ضوء منهج الإسلام.



الصحيح في ظل التحديات الدعاصرة، والتي أدت إلى التخلف والفرقة والتبعية.

(ץ) بيان أهية الهوية الإسلامية للحفاظ على كيان الأمة. 


\section{الهوية الإسلامية (روية تأصيلية في ضوء التحديات المعاصرة)}

(؟) إبراز مسئولية الدعوة والدعاة، والمؤسسات المختلفة وتضافرها في رد الأمة الإسلامية إلى مسارها الصحيح.



() التعرف على التحديات والأخطار المعاصرة التي تواجه الهوية



r الحفاظ على الهوية الإسلامية وغرسها، وتقويتها في نفوس الأجيال



r) بيان أسباب تهاون الأمة الإسلامية بهويتها، في مقابل تمسك الغرب

ع) بيان الثمار التي تعود على الأمة الإسلامية عند تمسكها بهويتها التي

$$
\text { تميزها عن غيرها. }
$$

$$
\text { ع - منهج البحث: }
$$

لقد استخدمت المنهج الاستقرائي التحليلي في كتابة هذا البحث، وذلك بقراءة







كما التزمت في البحث كتابة الآيات القرآنية بالرسم العثماني، وتخريج



$$
\text { 0- خطة البحث: }
$$

وقد جاءت هذه الدراسة بفضل الله تعالى تحت عنوان: 
الهوية الإسلامية (روئة تأصيلية في ضوء التحديات المعاصرة)

الهوية الإسلامية

رؤية تأصيلية في ضوء التحديات المعاصرة





المقدمة: وتثتمل على: أسباب اختيار البحث - أهمية البحث - أهداف

البحث - منهج البحث - خطة البحث.

الفصل الأول: حقيقة الهوية الإسلامية.



المبحث الأول: معنى الهوية الإسلامية وأهميتها.

المبحث الثاني: خصائص الهوية الإسلامية وحقيقتها.





المبحث الأول: العولمة وأثرها على الهوية الإسلامية.

المبحث الثاني: الغزو الفكري وأثره على الهوية الإسلامية.



التحديات المعاصرة.



المبحث الأول:دور المؤسسات الدعوية والاجتماعية لترسيخ الهوية في



أولاً : مسئولية العلماء والدعاة في حماية الهوية وتدعيمها في نفوس



ثانياً : مسئولية الأسرة في تحصين الأبناء لصيانة الهوية.



$-10 \leqslant-$ 
الهوية الإسلامية (روية تأصيلية في ضوء التحديات المعاصرة)
الأجيال المعاصرة.
رابعاً : مسئولية الحكام والولاة في الحفاظ على هوية الأمة. خامساً : دور وسائل الإعلام في نثر الوعي والحفاظ على الهام الهوية.

 1- الهوية بين تهاون العالم الإسلامي وحفاظ الغرب. r - r أساليب طمس الهوية الإسلامية. r- ثمار تمسك العالم الإسلامي بالهوية في ضوائه الإسلايه التحديات المعاصرة.

 البحث. والله تعالى أسأل أن يجعل هذا العمل خالصا لوجهه الكريم، وأن يمن علينا بالتوفيق والرشاد

$$
\text { وآخر دعوانا أن الحمد لله رب العالمين }
$$
وصل اللهم على سيدنا محمد وعلى آله وصحبه وسلم.


الهوية الإسلامية (روية تأصيلية في ضوء التحديات المعاصرة)

\author{
الفصل الأول \\ حقيقة الهوية الإسلامية الأية

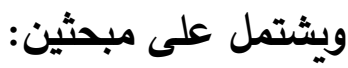 \\ المبحث الأول: معنى الهوية الإسلامية وأهميتها. \\ المبحث الثاني: خصائص الهوية الإسلامية وحقيقتها.
}


الهوية الإسلامية (روئة تأصيلية في ضوء التحديات المعاصرة)

 \\ حقيقة الهوية الإسلامية الاولية}

إن موضوع الهوية الإسلامية من أهم الموضوعات التي يجب الإسياته العناية بها،




له الجبين، وتحترق له القلوب المؤمنة، ليتحرك العلماء والدعاة والمفكرون استشعارا








إلى سالف عهدها

إن الحديث عن الهوية الإسلامية في الواقع المعاصر، وفي الوقت الذي












بدون محتوى فكري أو رصيد حضاري، ومن ثم تتفكك أواصر الولاء بين أفرادها،




وتطمس معالم وجودها، وتمحو آثارها من ذاكرة التاريخ.

ولما كانت الهوية بهذه المكانة وهذا التأثير في حياة الأمم فقد أولاها 


\section{الهوية الإسلامية (روية تأصيلية في ضوء التحديات المعاصرة)}

الإسلام اهتماما كبيرا، شمل هذا الاهتمام جوهر الهوية ومظهرها، فانظر إلى ددى


واللباس أو الحركة و السلوك، أو القول والأدب (') وسوف أتناول هذا الموضوع في المبحثين التاليين:

\section{المبحث الأول \\ معنى الهوية الإسلامية و أهميتها}





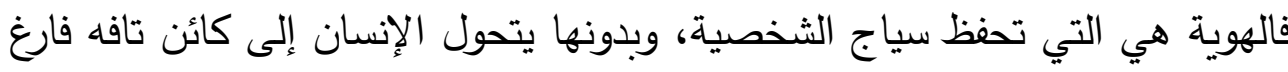


تحديد سمات شخصيته، فتجعله إنسانا ذا قيمة ولحياته معنى وغاية.

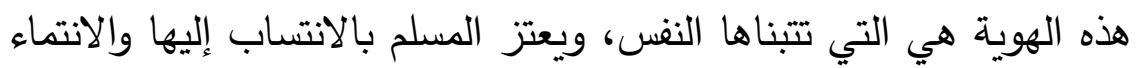


تعتبر الهوية الحصن الذي يتحصن به أبناؤه، والمادة اللاصقة بين لبناته، فإذاذا فقدات تشتت المجتمع، وتتازعته المتناقضات. فإذا توافقت هوية الفرد مع هوية مجتمعه كان الأمن والراحة والإحساس



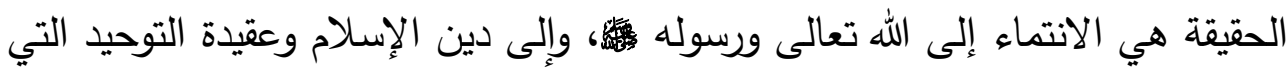

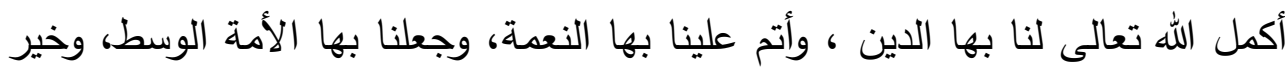

ا I - الهوية الإسلامية والمؤامرة عليها : د ـ ناصر دسوقي رمضان ، مقال على الثبكة العنكوتية ، موقع www.alukah.net/sharia/0/8744 
الهوية الإسلامية (روية تأصيلية في ضوء التحديات المعاصرة)

أمة أخرجت للناس، وصبغنا بفضلها بخير صبغة

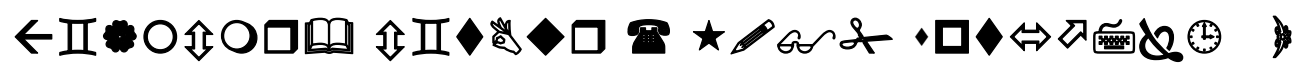

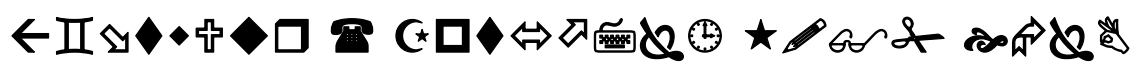

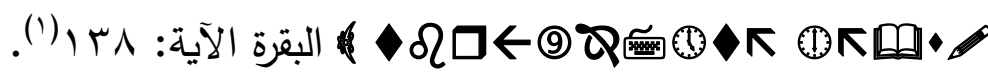

1 - معنى الهوية لغة واصطلاحا:

أ) معنى الهوية في اللغة:

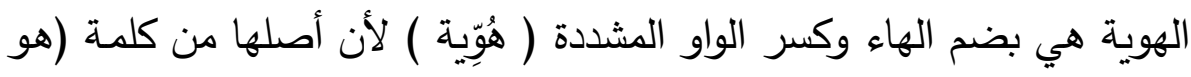


بفتح الهاء بل بضمها.

لأن ( الهَوِيـة ) هي البئر العميقة، وجمعها هويـات، كما أن ( الهُوَيـة ) بضم الهاء وفتح الواو تصغير

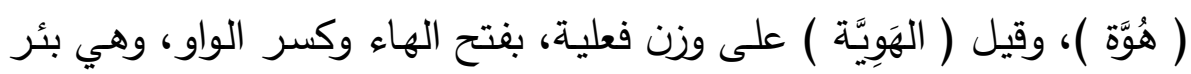

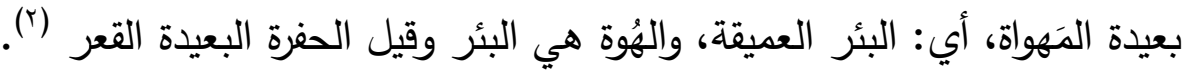

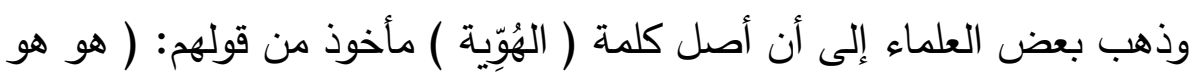

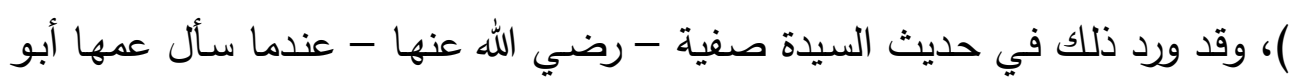

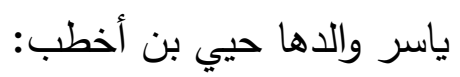

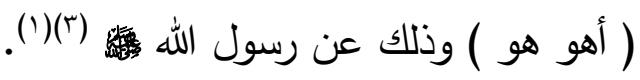

1 - صراع الهويات وخصائص الهوية الإنلامية : ، موقع الشبكة الإنلامية على الإنترنت www.islam web.ket/media/index.php?bage=article\&lang=a\&id=63232

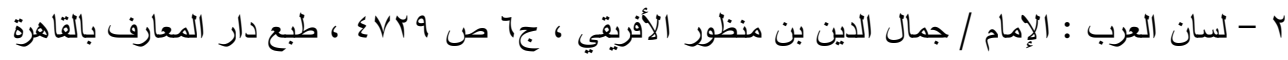

r - مجلة البيان اللبنانية : د ـ محمد إسماعيل المقدم ، موقع المجلة على الثبكة المعلوماتية www.albayan.magazine.com/dialagues110/.ht 


\section{الهوية الإسلامية (روية تأصيلية في ضوء التحديات المعاصرة)}

وتستعمل كلمة الهوية في الأدبيات المعاصرة لأداء معنى كلمة identity التي

تعبر عن خاصية المطابقة: مطابقة الثيء لنفسه أو مطابقته للثيله (؟).

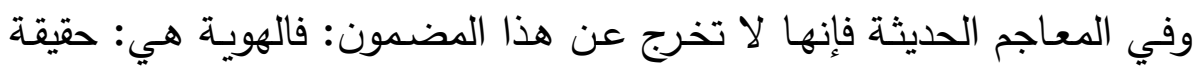
الثيء أو الشخص المطلقة، المشتملة على صفاته الجوهرية، والتي تميزه عن غيره، وتسمى أيضا وحدة الذات (r). ب) معنى الهوية في الاصطلاح: لقد عرف العلماء الهوية بعدة تعريفات أذكر منها ما يلي: الهملئ

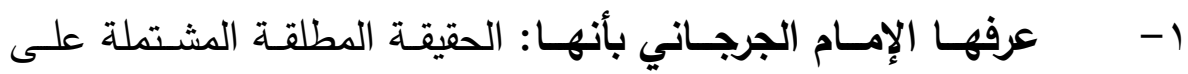

الحقائق اشتمال النواة على الثجرة في الغيب (ء).

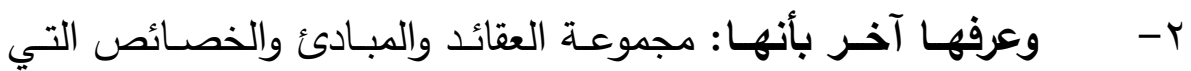

تجعل أمة ما تشعر بمغايرتها للأمم الأخرى ().

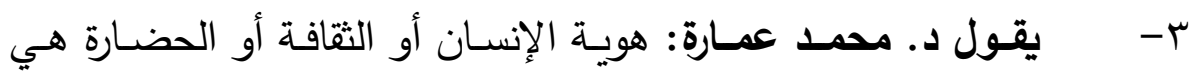



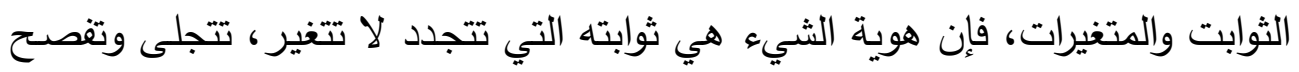

1 - دلاثل النبوة للبيهي : باب : ما جاء في دخول عبد الله بن سلام ، حديث رقم : V10 ، وقال : حديث



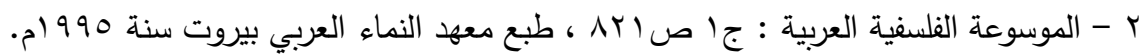

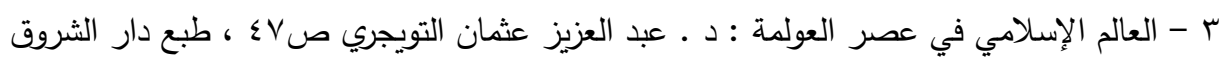

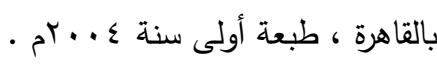

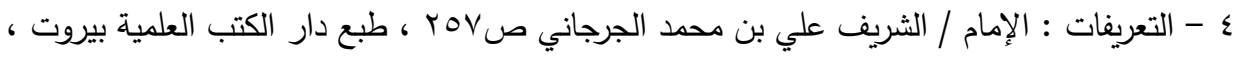

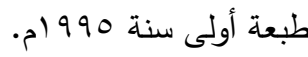
ه - تجديد الوعي : د . عبد الكريم بكار ص99 198 ، طبع دار القلم دمشق ، طبعة أولى سنة ... بام . 


\section{الهوية الإسلامية (روية تأصيلية في ضوء التحديات المعاصرة)}

عن ذاتها دون أن تخلي مكانها لنقيضها طالما بقيت الذات على قيد الحياة(').

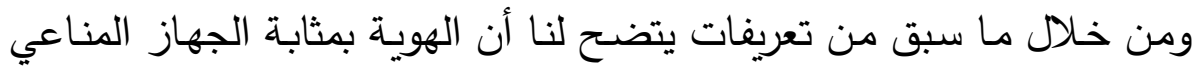

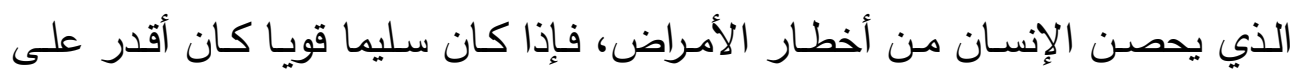
الدفاع والمواجهة والعكس.

وكذلك المسلم فالهويـة إذن مـا يميز الأمسة عن غيرهـا من الأمم الأخرى، من ون

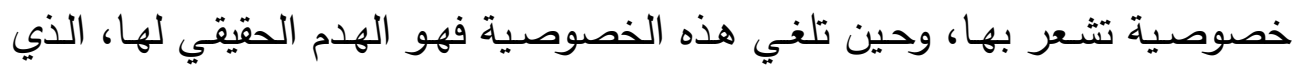

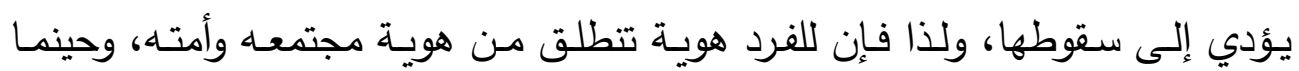


الثـعورية، وهو نفس ما يشعر بـه المنسلخين من هويتهم من الليبراليين والعلمانيين

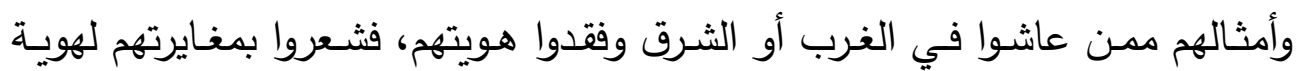
أمتهم وغربتهم في أوطانهم (؟).

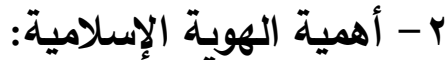

إن للهويـة الإسـامية أهمية عظمى في حياة المسلمين، لأنها تتميز بارتكازهـا

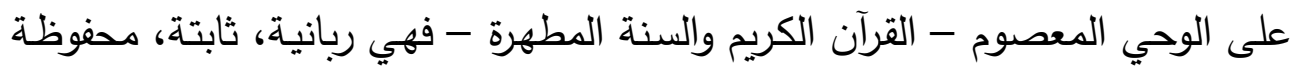



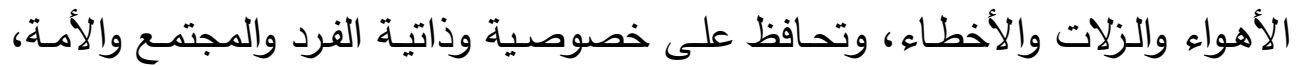
وتتهى عن التبعية المقيتة لغيرها.

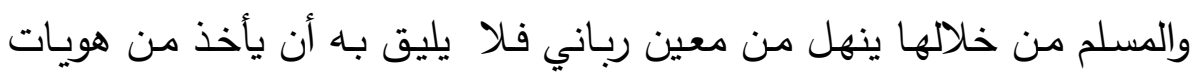
أخرى نتجت عن عقول البشر القاصرة، التي تتغير وتتبدل حسب الأهواء والثهوات. 1 ، مخاطر العولمة على الهوية الثقافية : د ـ محمد عمارة ص7 ، طبع دار نهضة مصر للطباعة والنشر

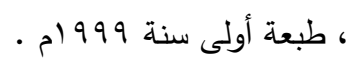

2 - www.shobhat. Com./vp/showthread:php?t=11028 


\section{الهوية الإسلامية (روية تأصيلية في ضوء التحديات المعاصرة)}

$$
\text { يقول الأستاذ / سيد قطب: }
$$

ولا شك أن ذلك يعطي لهذه الهوية عمقا تاريخيا ويبرهن عن عظمتها وقوتها التي استطاعت أن تستمر عبر ما مضى من قرون وسنوات، فليست منهجا مهترا لم يولد إلا قبل سنوات، أو فكرا جري تعديله وتصويبه المرات تلو المرات، بل هو ثابت لا يحتاج في ذاتة إلى التطور والتغير ، فالذي وضسعه يرى بـلا حدود من الزمـان

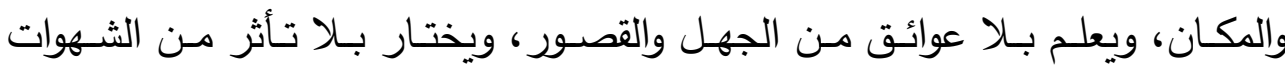

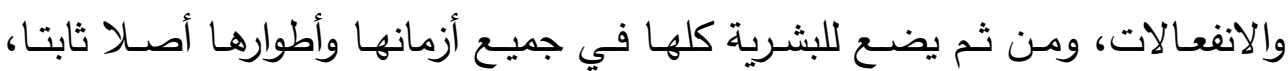
تتطور هي في حدوده وترتقي وتتقدم وتنمو ( ').

فالهوية الإسلامية متفردة لا تقبل القسمة لأنها هوية واحدة لا تتغير ولا تتبدل

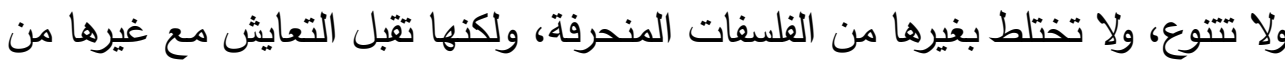

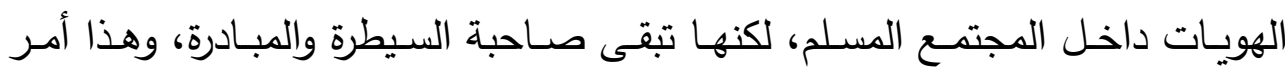
طبيعي بديهي إذ إن صاحب الحق لا يقبل بغيره مسيطرا عليه، ولو قبل فذلك دليل

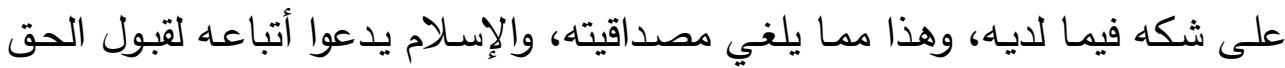

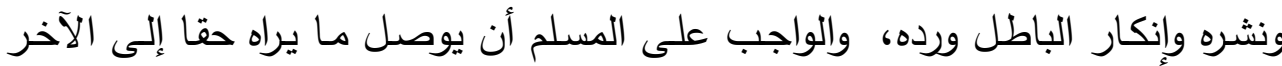

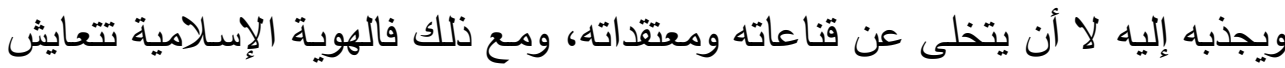
مع الآخر ، وتعطي لله مساحة يتحرك فيها متحفظا بهويته دون أن تمس، فهي أولاعلا:

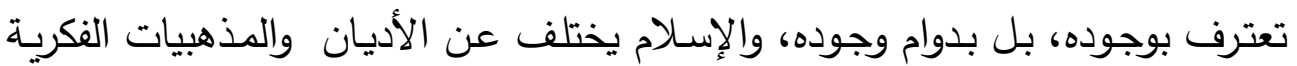

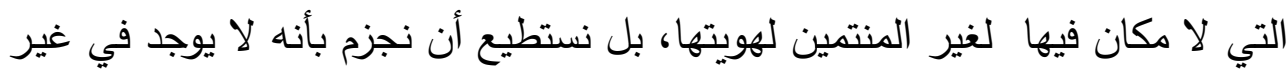

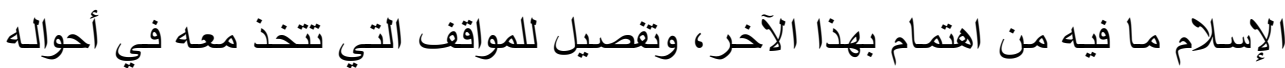

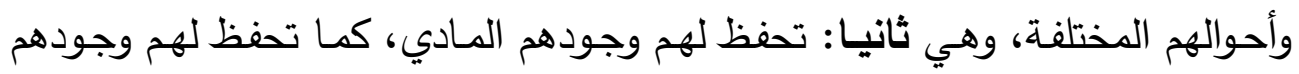

1 - خصائص التصور الإسلامي : الأستاذ / سيد قطب ، ص اء بتصرف ، طبع دار الشروق بالقاهرة،

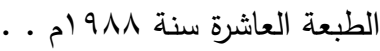




\section{الهوية الإسلامية (روية تأصيلية في ضوء التحديات المعاصرة)}

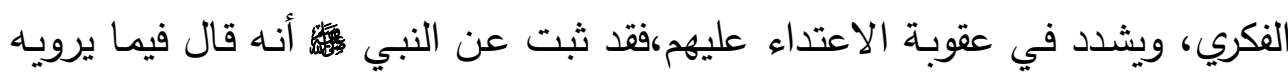

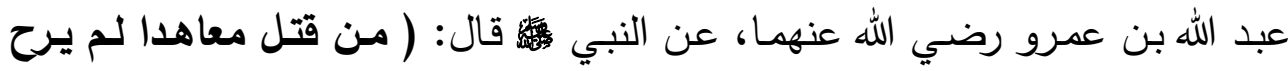

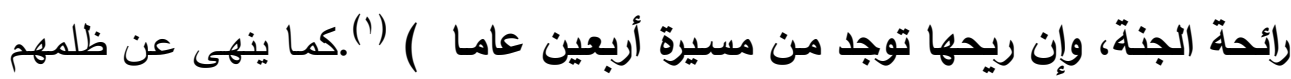
والاعتداء عليهم، وثالثا: فهي تحفظ عليهم هويتهم فلا يجبرون على التخلي عنها،

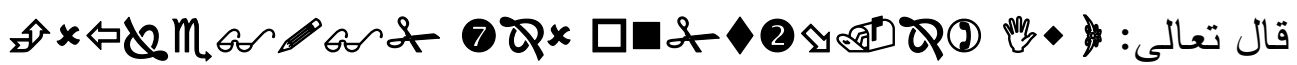

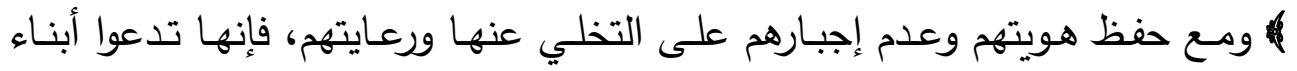

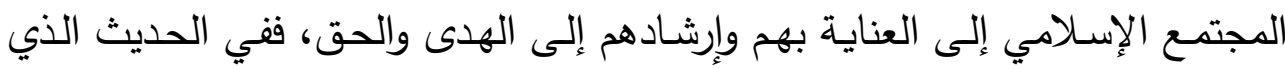

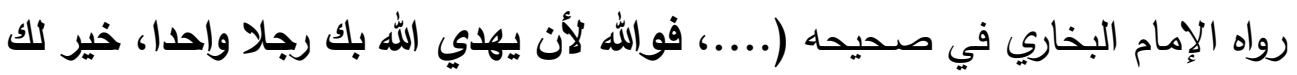

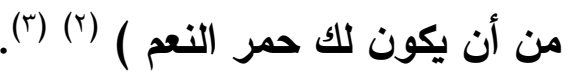
إن الحديث اليوم عن الهوية الإسلامية في ظل الأزمة التي تعيشها ويعيشها

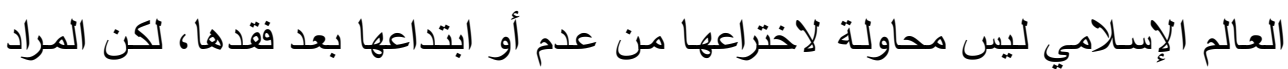

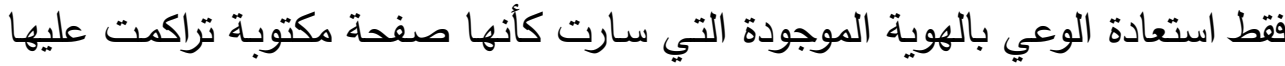
طبقات الأتربة، في ظل الفكر الوافد المحارب لهذه الهوية، والذي توافرت له الوسائل


تعرضت هوية سواها لنصف ما تعرضت له من الحروب والهجمات والتسلط لاندثرت وكانت نسيا منسيا، لكن هذه الهويـة العظيمة محفوظة بحفظ الله تعالى لها، الذي لـاهي

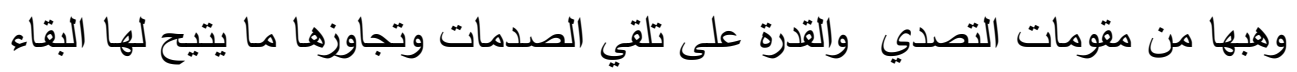

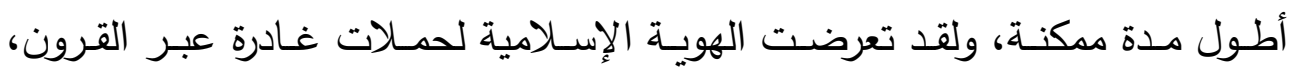



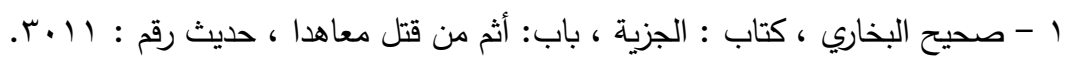


r - صدام الحضارات : د ـ جعفر شيخ إدريس ،مقال منشور في موقعه على الثبكة العالمية www0gaafariris.com 


\section{الهوية الإسلامية (روية تأصيلية في ضوء التحديات المعاصرة)}

الحملات أعداء الإسلام بما ألقوه من شبهات، وما جاءوا به من فلسفات وثقافات (').

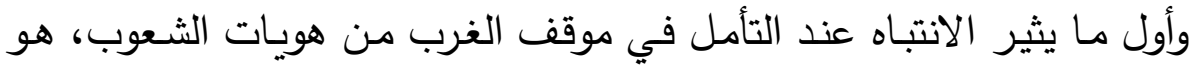
جمعه بين موقفين متناقضين، فهو من جهة شديد الاعتزاز بهويته حريص عليها، وهو الاهو من جهة ثانية رافض للاعتراف بالهويات الوطنية لشعوب العالم (؟).

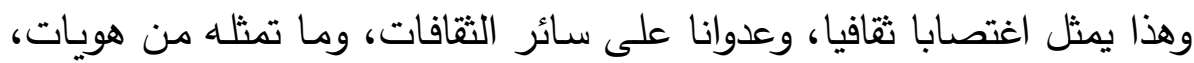

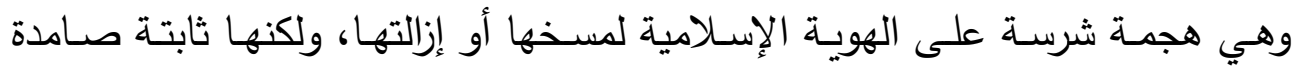
فعالة إلى يوم الدين.

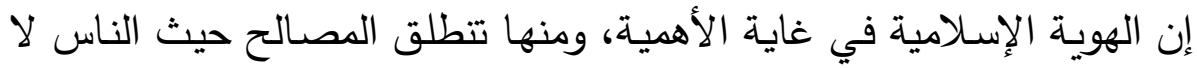

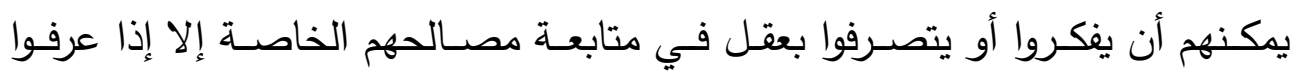

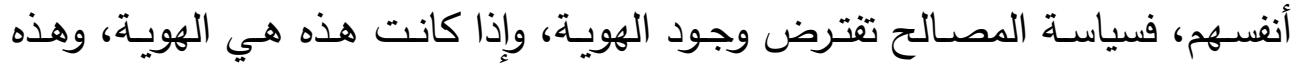

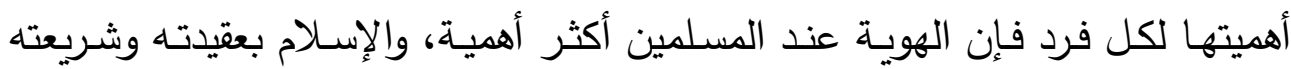

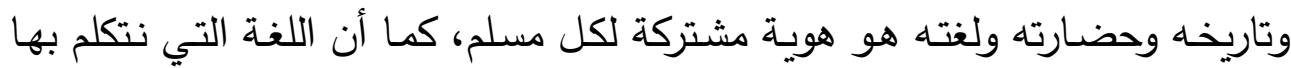
ليست مجرد أداة تعبير ووسيلة تخاطب، إنما هي: الفكر والذات والعنوان، بل ولهال



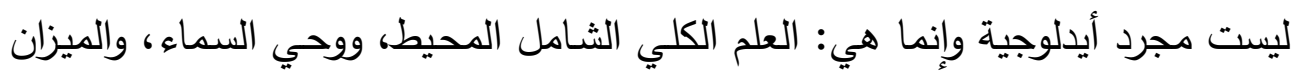

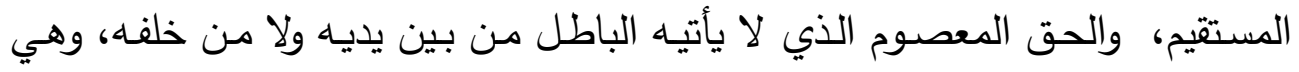

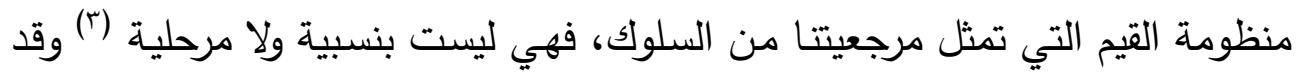
أدرك الأعداء ذلك، حيث إن الصليبية والثيوعية والصكيونية اليوم ترى أن استعادة

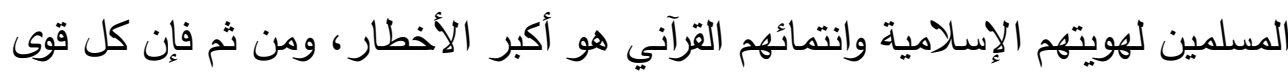

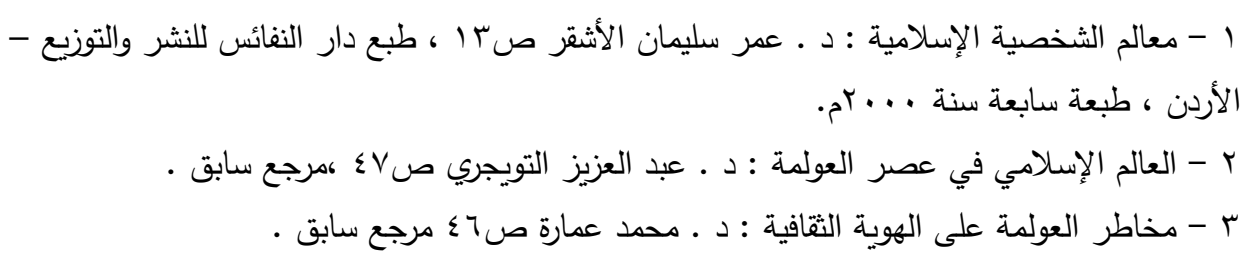




\section{الهوية الإسلامية (روية تأصيلية في ضوء التحديات المعاصرة)}

التغريب والغزو الثقافي ستنطلق في هذا الاتجاه، ويقوم الاستشراق والتتصير بدور كبير ، كما أن الغرب أحرص ما يكون على هويتهم، وعلى ذوبان المسلمين الهاجرين

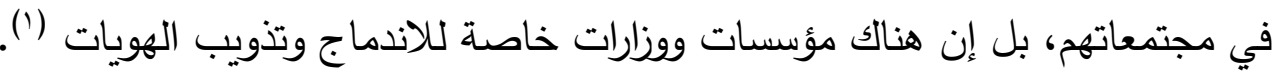

ا - حتى لا تضيع الهوية الإسلامية والانتماء القرآني : الأستاذ / أنور الجندي ص V، طبع دار الاعتصام

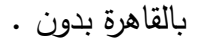


الهوية الإسلامية (روية تأصيلية في ضوء التحديات المعاصرة)

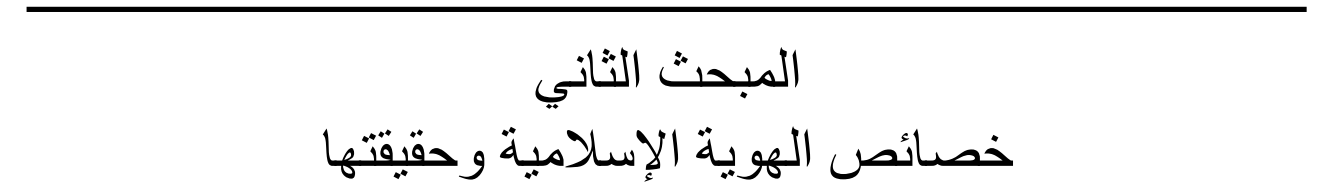

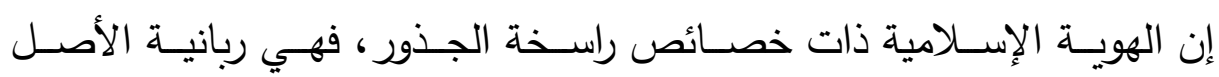

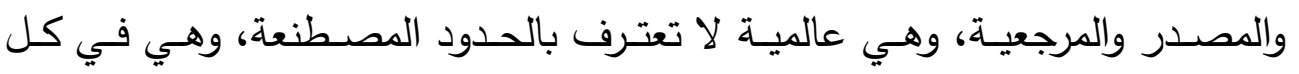

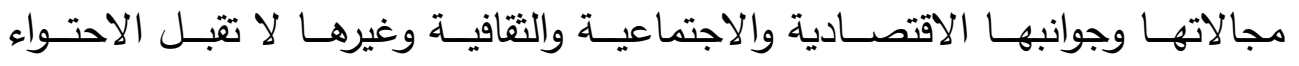

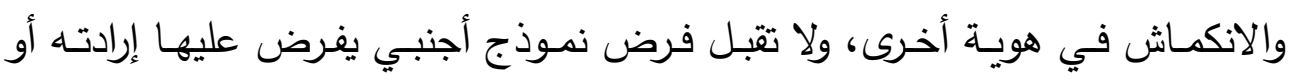

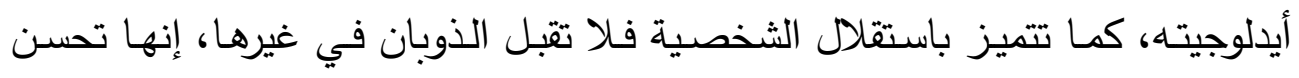

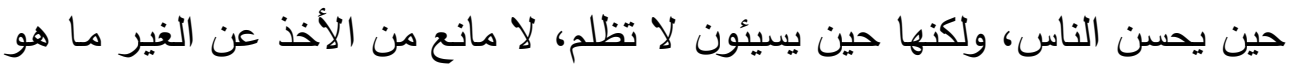

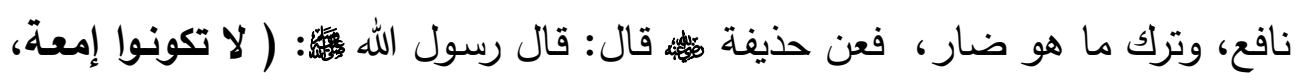

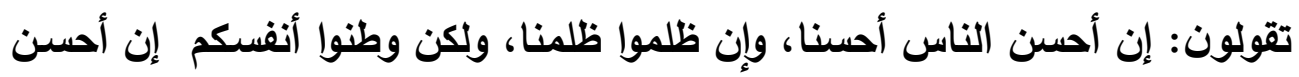

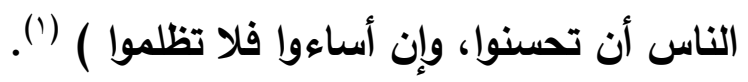

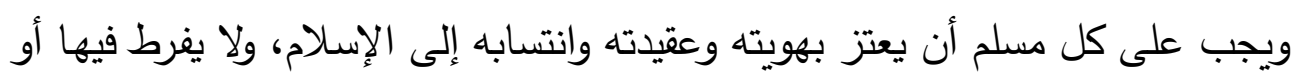

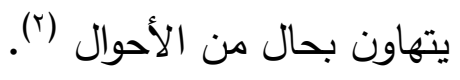
إن لكل هوية خصائص تميزها عن غيرها، والهوية الإسلامية لها خصائص التصان تميزها

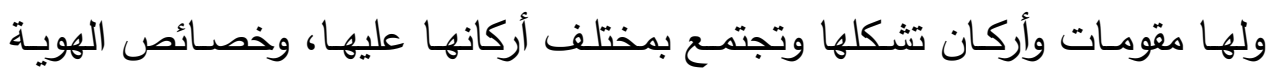

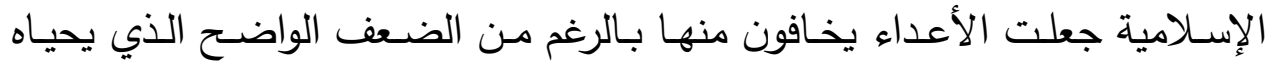

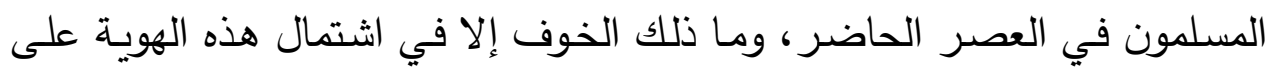
خصائص معينة جعلتها قادرة على صهر الهويات الأخرى في بوتتتها في أي حالة فئل سواء أكانت قوية أم ضعيفة.

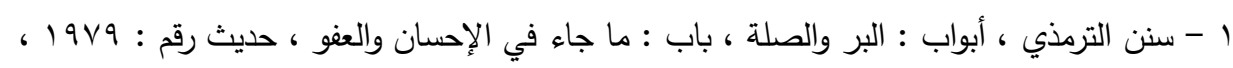

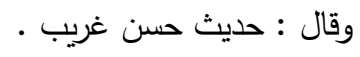
r - خصائص الهوية الإسلامي : د ـ أحمد عمر هاشم ، مقال منقول من جريدة الأخبار منشور على شبكة

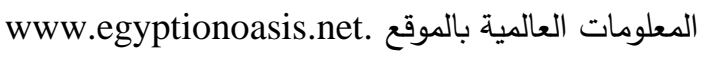


الهوية الإسلامية (روية تأصيلية في ضوء التحديات المعاصرة)

1 - أذصائص الهوية الإسلامية:

وسوف أذكر أهم هذه الخصائص في النقاط التالية:

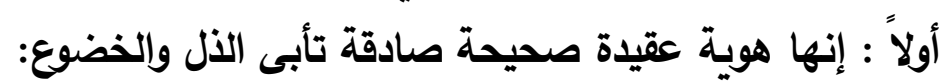

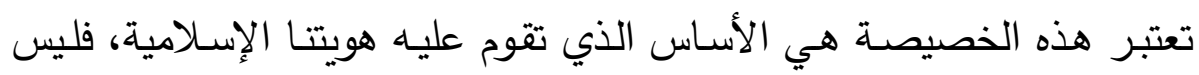

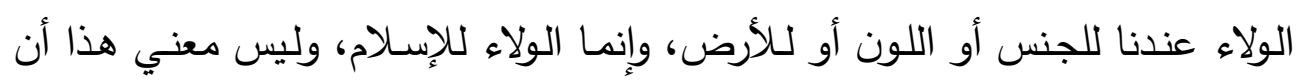

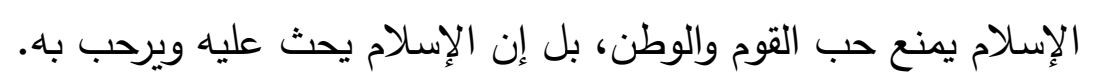
وهنا يظهر الفرق بين حب ذي العقيدة الصحيحة لقومهه ووطنه، وحب أدعياء القومية والوطنية، فالمسلم الصحيح يعتبر حدود الوطنية بالعقيدة، والقوميون والوطنيون

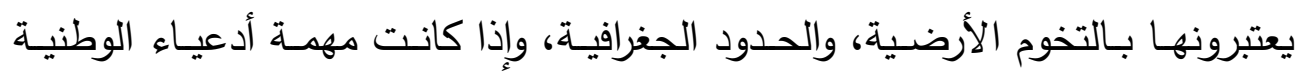

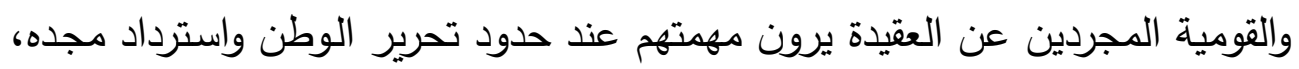

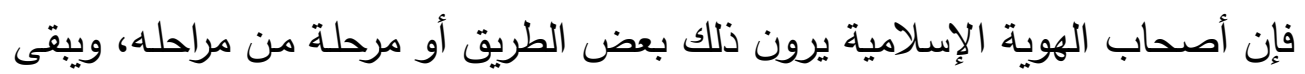

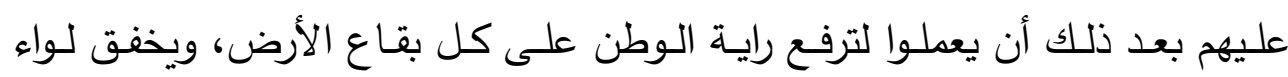
المصحف في كل مكان (') ولعل هذا الجمع بين الولاء للعقيدة والانتمـاء والحب للقوم والوطن يعد من البدائع التي وفق بها الإسلام بين أمرين قد يبدوان متتاقضين:

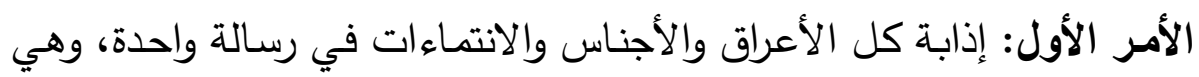
الإسلام.

الأمر الثاني:عدم إلغاء انتماء الأفراد والجماعات للقبائل والأجناس واللغات،

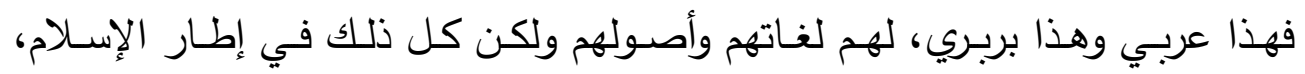
والتفاضل بالتقوى، وكونها عقيدة صادقة جعلها تغرس في نفوس أبنائها حب الجهاد

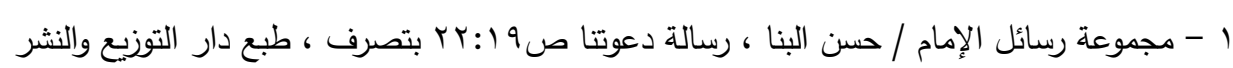
الإسلامية بالقاهرة . 


\section{الهوية الإسلامية (روية تأصيلية في ضوء التحديات المعاصرة)}

والثهادة، والاستعلاء على الخضوع للغزاة، ويعتبر هذا من أخوف ما يخافه الأعداء،

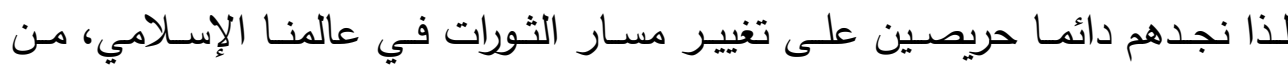

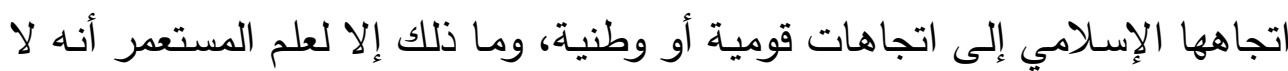

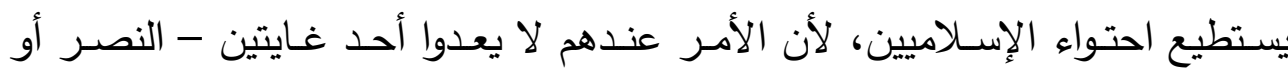

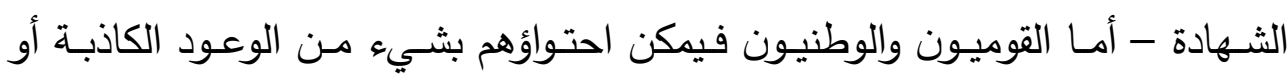

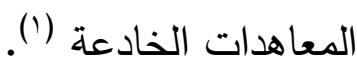

إن خطر القوة الكامنة في العقيدة على الاستعمار ينبع أولا من أن الإسلام قوة تحريرية

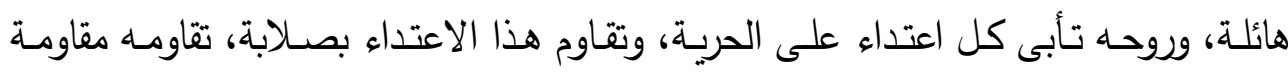

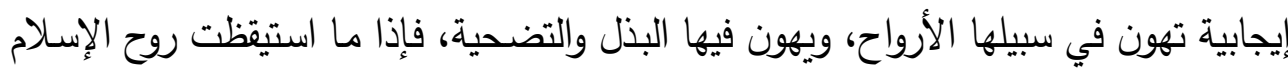

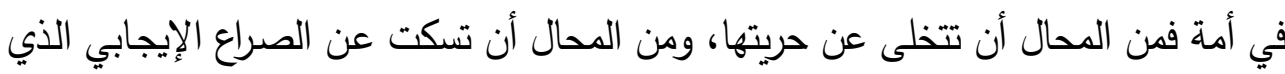
يحطم قواعد الاستعمار تحطيما.

كذلك ينبع الخطر على الاستعمار في العقيدة الإسلامية من أنها: عقيدة

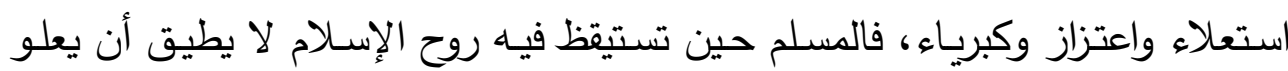

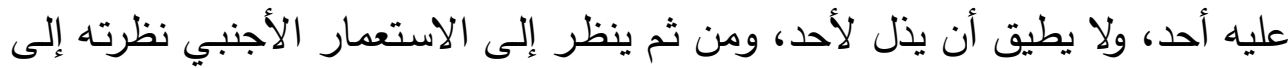

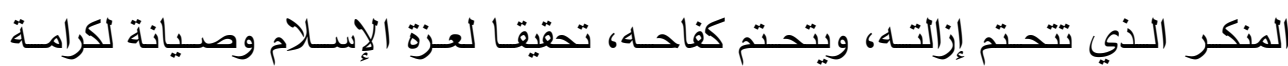
المسلمين، وابتغاء لمرضاة الله تعالى.

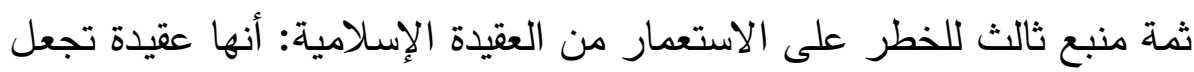

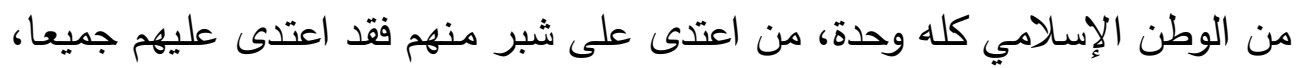

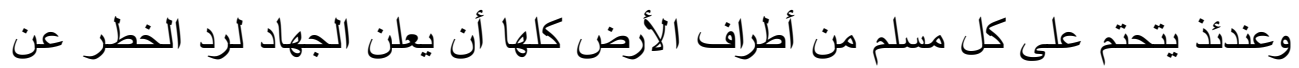

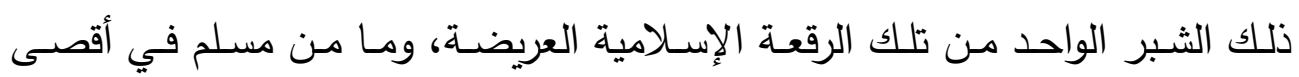

1 - واقعنا المعاصر : الأستاذ / محمد قطب صبr ، ، طبع مؤسسة المدينة للطباعة والنشر ، طبعة أولى

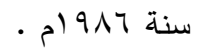


الهوية الإسلامية (روية تأصيلية في ضوء التحديات المعاصرة)

الأرض، ما من مسلم حق يسمع أو يعلم أن عدوا داس على شبر من أرض الإسلام

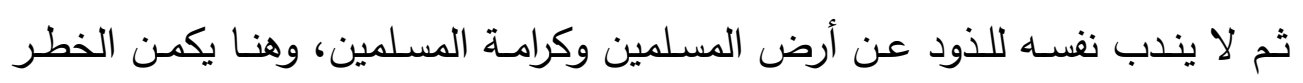

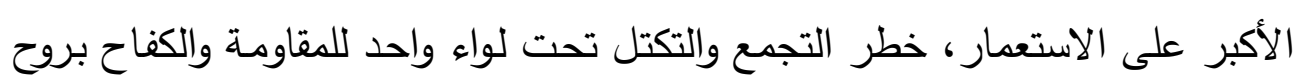
التضحية والفذاء (')

ثانياً : هيمنتها وشموليتها وملازمتها لجوانب الإنسان وأطوار حياته:

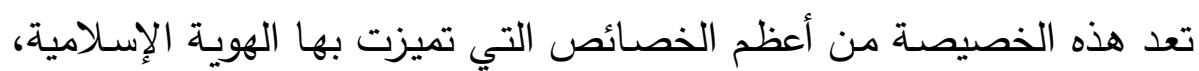
والتي كانت سببا في إذابتها لكثير من الهويات في بوتقتها.

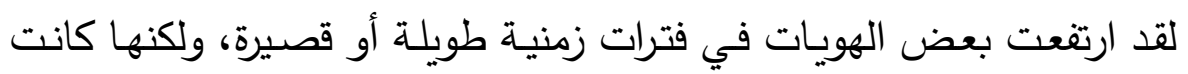

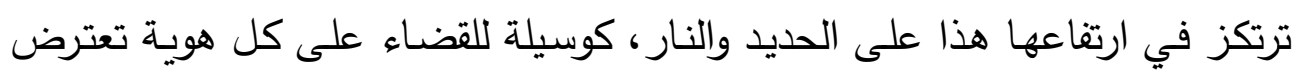
طريقها. أمـا الهويـة الإسـلامية فإنها في سـعيها للارتفـاع تسعى لفتح الإنسـان عبر

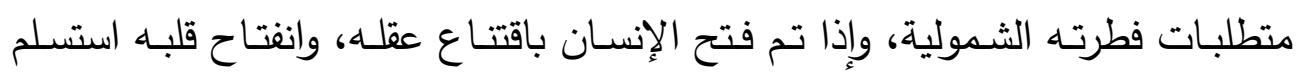

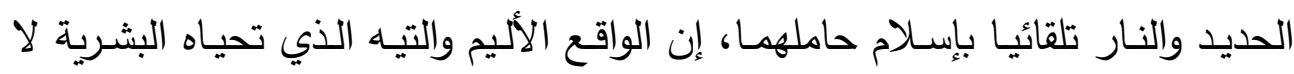

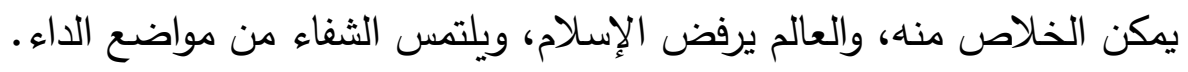

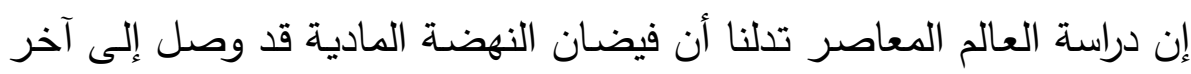

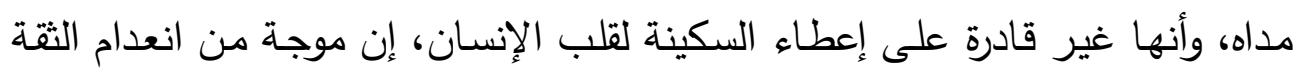

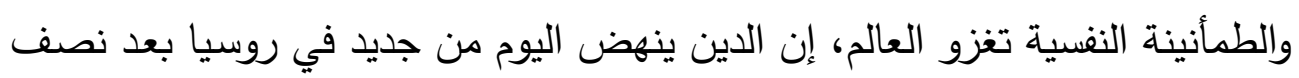

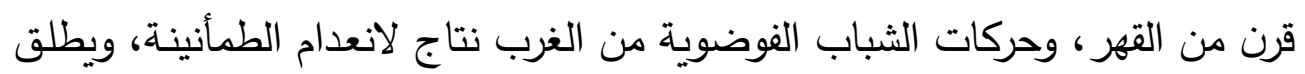
شباب اليابان أسم

1 - دراسات إسلامية : الأستاذ / سيد قطب ص • V ، ، طبع دار الثروق بالقاهرة ، طبعة عاشرة سنة • 
الهوية الإسلامية (روية تأصيلية في ضوء التحديات المعاصرة)

( ثقافة التجارة ) على ثقافتهم التي لا توافق سوى جزء من حاجات الوجود

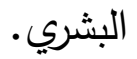

إن داء القلق وانعدام الثقة قد غزا الجيل الجديد في العالم كله، إن هذه الأحوال

تتيح فرصة ذهبية لحاملي دين الفطرة لإرواء عطش العالم ولإظهار دين الله تعالى (').

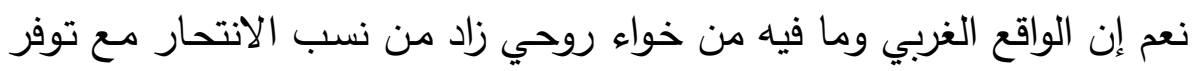

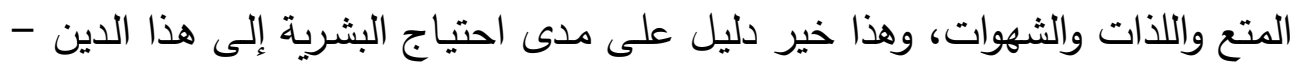
دين الفطرة التي فطر الله الناس عليها - الذي يشبع في النفس البشرية كل متطلباتها،

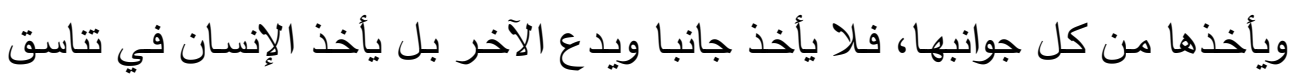

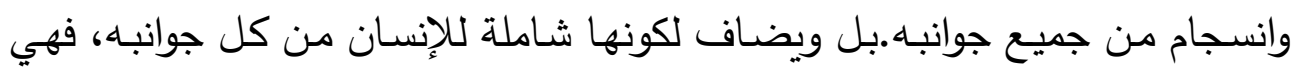

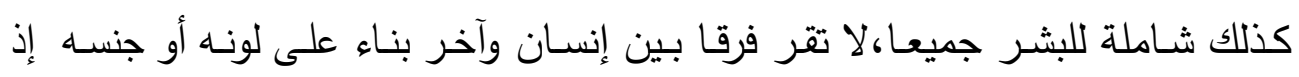

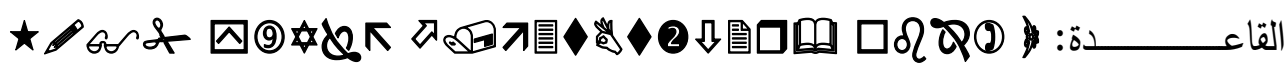

(الحجرات

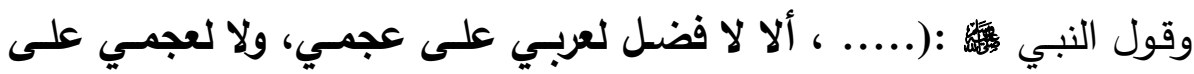

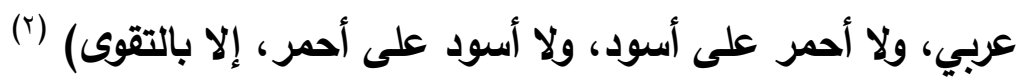

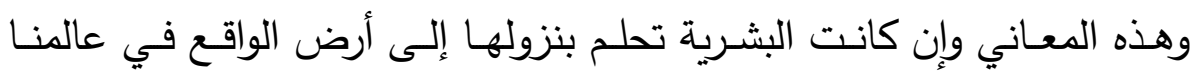

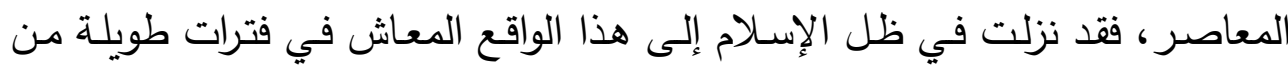
التاريخ الإسلامي.

نعم أوليست هويتا الإسلامية هي التي جعلت عطاء بن أبي رباح إمام أهل

مكة، وعالمها وفقيهها، وقد كان مولى لبني فهر ؟!.

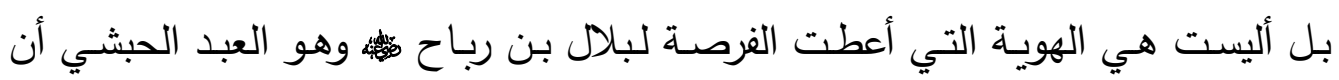
، - الإسلام والعصر الحيث : الأستاذ / وحيد الدين خان صاه ه ، طبع مطبعة الهختار الإسلامي بالقاهرة

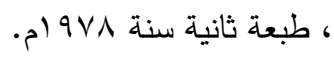

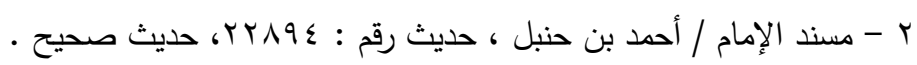
$-1 V \cdot-$ 


\section{الهوية الإسلامية (روية تأصيلية في ضوء التحديات المعاصرة)}

يصعد فوق الكعبة ليؤذن وبجواره الكثير من أشراف العرب؟! (').

فانظر إلى هذا المستوى من الإنسانية التي تميزت بها هويتتا الإنسلامية، على لهى

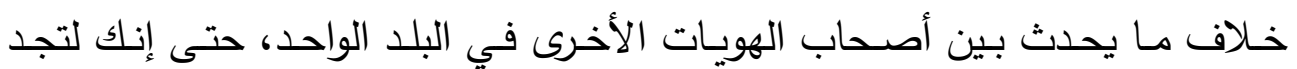

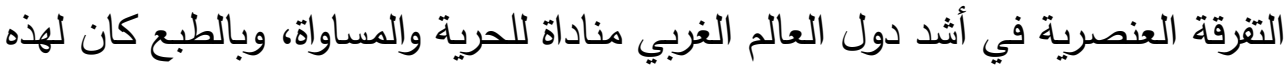
الخصيصة أعظم الأثر في إقبال الناس على الإسلام ودخولهم فيه. ثالثاً : هوية حيوية قادرة على إخضاع الهويات الأخرى:

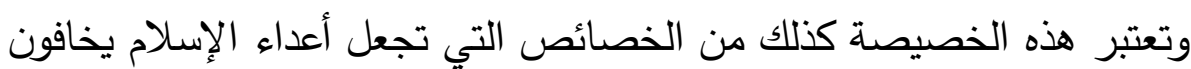

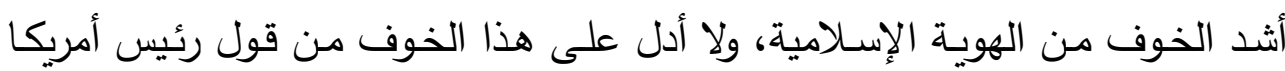

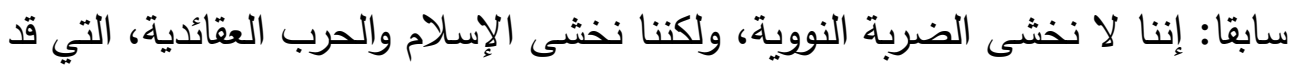
تقضي على الهوية الذاتية للغرب.

ولقد تحدث علمـاء الغرب عن حيويـة الإسـلام وقدرته على استيعاب أطوار الحياة، وقدرته كذلك على توليد أفكار جديدة، ومن هؤلاء العلماء ( هوكنج ) أستاذ الفلسفة في جامعـة هارفارد حيث يقول في كتابه " روح السياسـة العالميـة ": أحيانـا

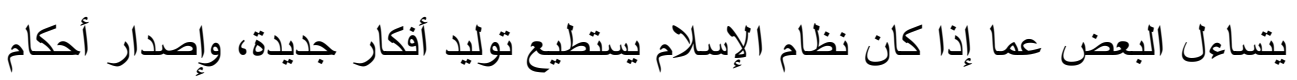

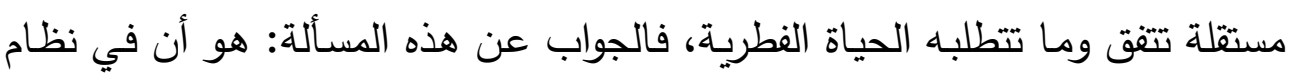
الإسلام كل استعداد داخلي للنمو، بل إنه من حيث قابليته للتطور يفضل كثيرا من النظم

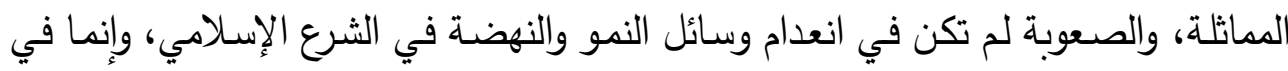

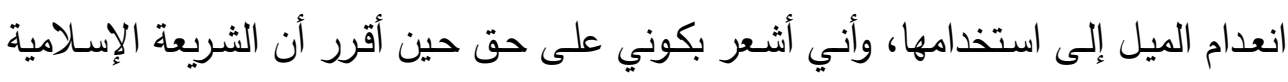
تحتوي بوفرة على جميع المبادئ اللازمة للنهوض.

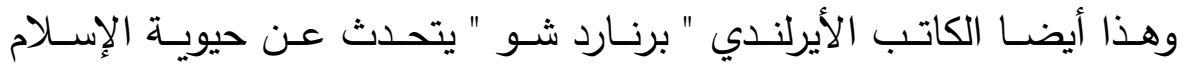

1 - من روائع حضارتنا : د ـ مصطفى السباعي صل؟T ، طبع دار السلام للطباعة والنشر والتوزيع

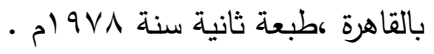


الهوية الإسلامية (روية تأصيلية في ضوء التحديات المعاصرة)

واستيعابه أطوار الحياة المختلفة فيقول: الإسلام هو الدين الوحيد الذي يمتلك القدرة على استيعاب أطوار الحياة المختلفة في كل العصور ".

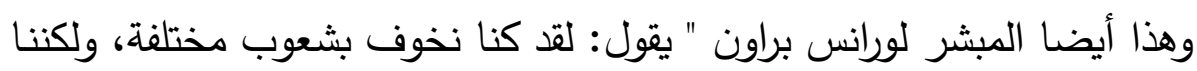

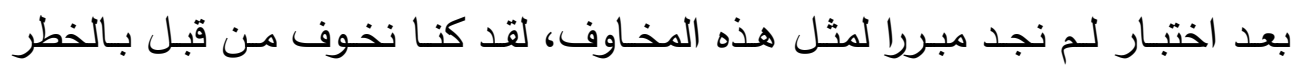
اليهودي، وبالخطر الأصفر وبالخطر البلشفي، إلا أن هذا كله لم يتفق كما تخيلناه، إننا وجدنا اليهود أصدقاء لنا ، وعلى هذا يكون كل مضطهر لها لهم عدونا الألد، ثم رأينا

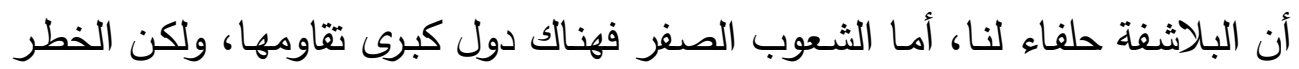

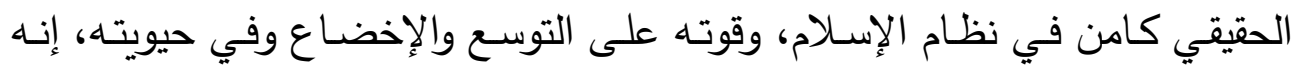
الجدار الوحيد في وجه الاستعمار الأوربي ('). فانظر إلى نصائح المبشرين لقوههم، بالرغم من أن الدفروض الوربي وهم يدعون أنهم

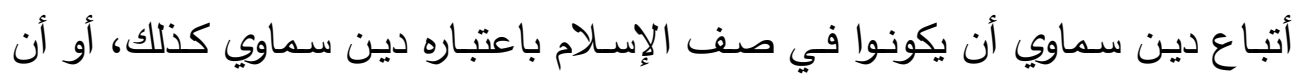

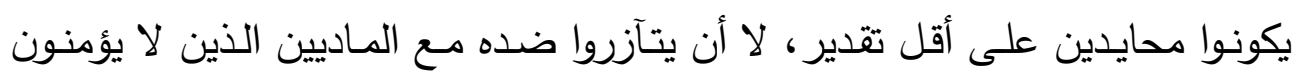

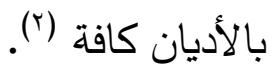

ولكن لا عجب فقد سبقهم سلف لهم من أهل الكتاب نهجوا أمامهم هذا المنهج،

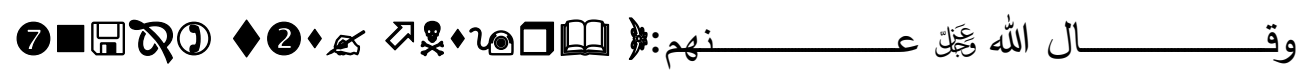

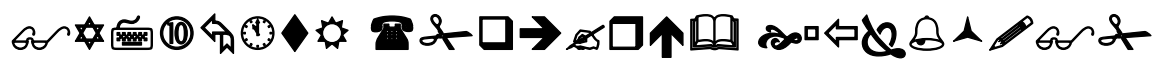

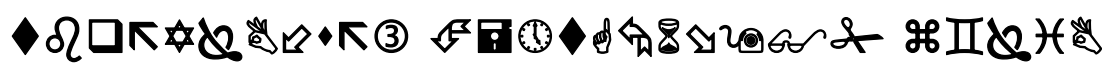

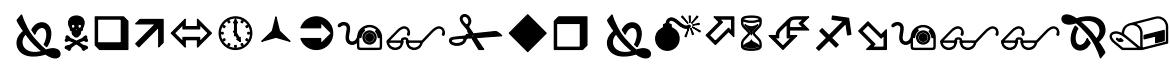

1 - أجنحة الككر الثلاثة : الأستاذ / عبد الرحمن حسن حبنكة الميداني صع ع ، طبع دار القلم دمشق ،

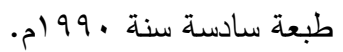
r - الهوية الإسلامية والمؤامرة عليها : د ـ ناصر دسوقي رمضان ، مقال منشور على شبكة الإنترنت موقع الألوكة 
الهوية الإسلامية (روية تأصيلية في ضوء التحديات المعاصرة)

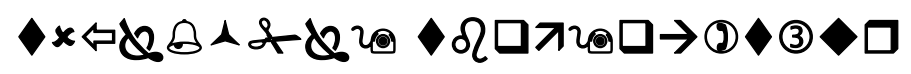

目8曰9ロ

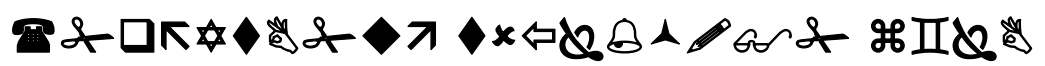

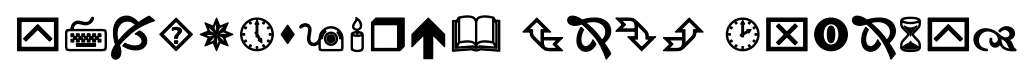

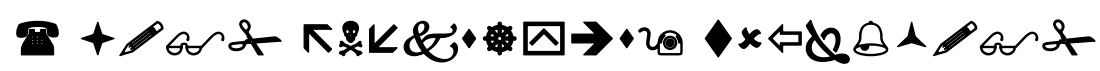

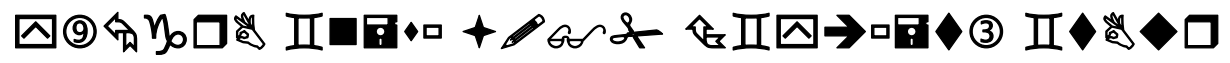

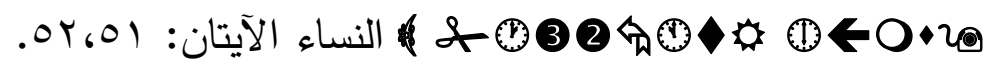
رابعاً : إنها هوية ربانية:

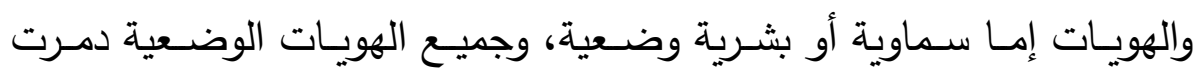

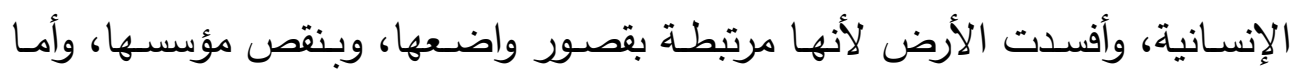

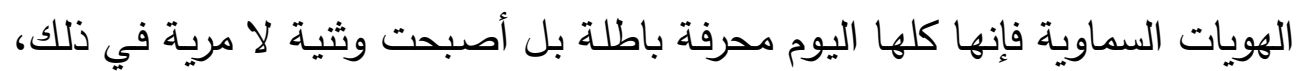

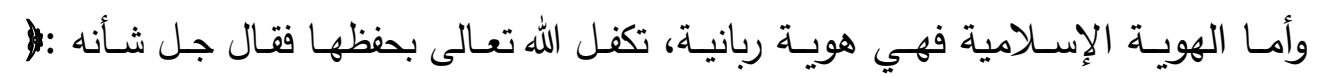

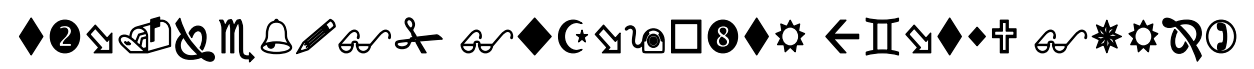

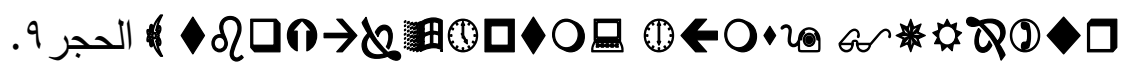

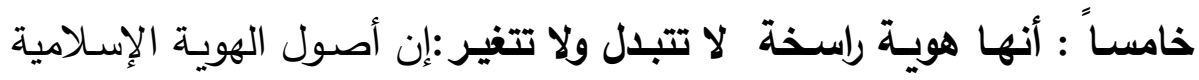

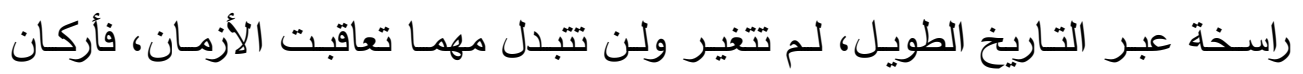

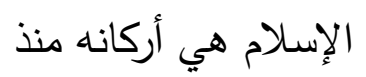

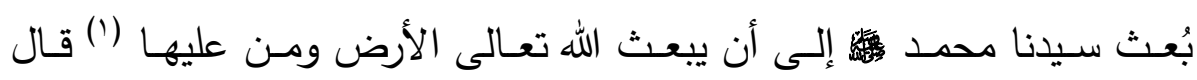

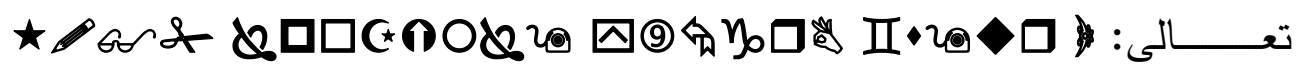

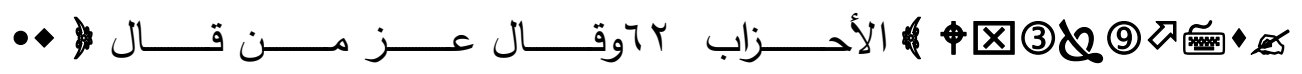

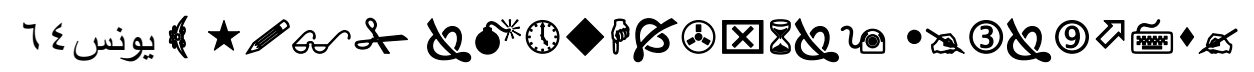


الهوية الإسلامية (روية تأصيلية في ضوء التحديات المعاصرة)

سادساً : الهوية الإسلامية تدعوا إلي التوكل على الله تعالى:

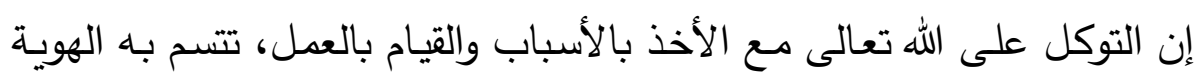

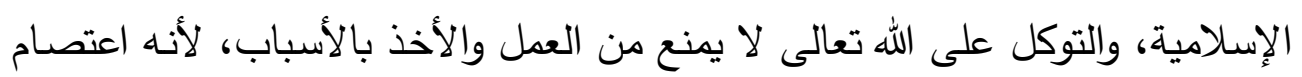

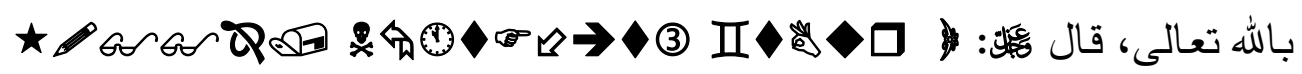

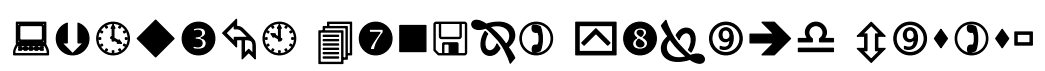

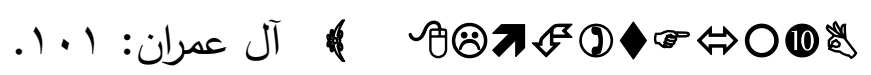

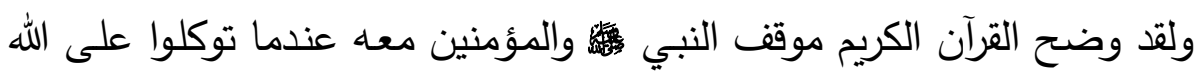

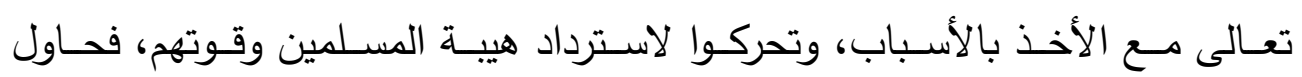

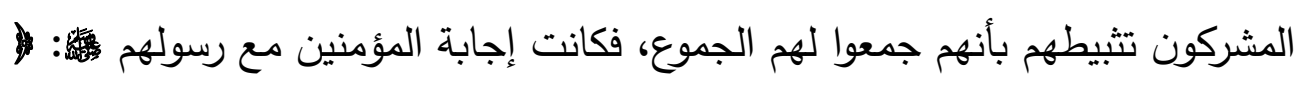

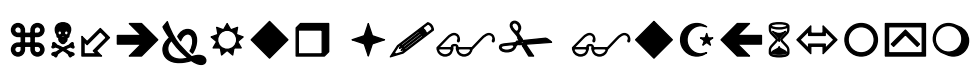

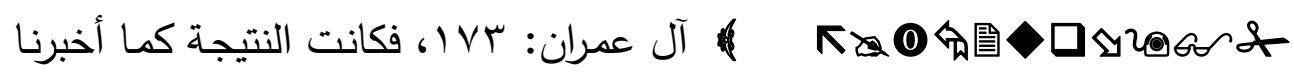
曾口内(i)

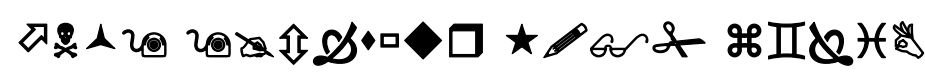

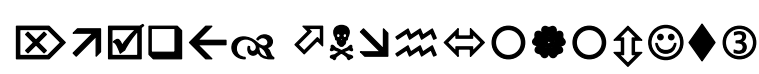

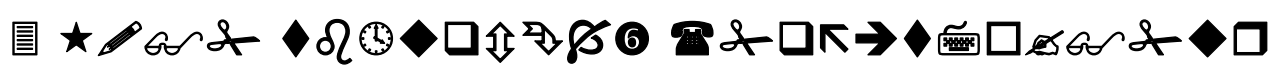
IV $\vee$ :

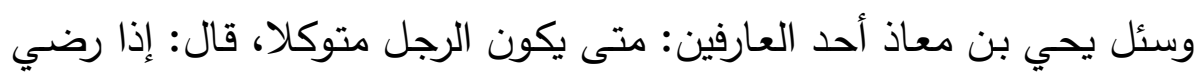

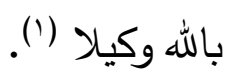
r- حقيقة الانتماء للهوية الإسلامية:

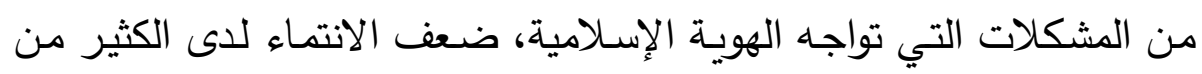

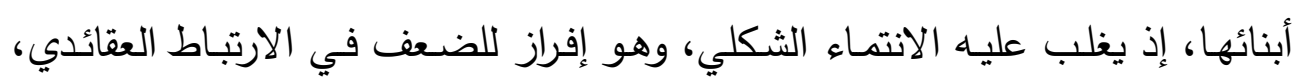




\section{الهوية الإسلامية (روية تأصيلية في ضوء التحديات المعاصرة)}

والاصــباغ المنهجـي بالمبـادئ التي تتضــنها الهويـة الإسـلامية، ولعـل الانتمـاء الحقيقي يكون إذا توفرت لله جملة من المواصفات التي ترتقي به من مجرد الانتماء

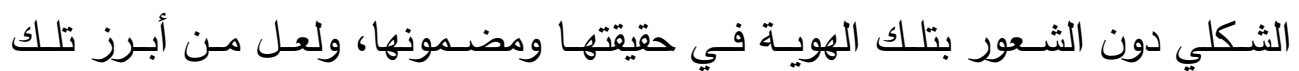

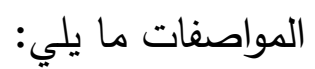

1- أن يكون انتماء حقيقيا لا وراثيا ولا عفويا، ولا عاطفيا، لأن الإسلام منهج حياة، يقوم على مفاهيم دحددة عن الكون والإنسان والحياة، فعدم إدراك هذه

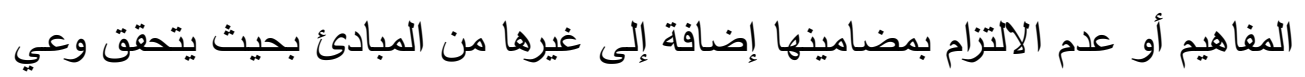
عقدي والتزام فكري يجعله انتماء عاطفيا عفويا أو بالوراثة ولا يحقق المراد منه.

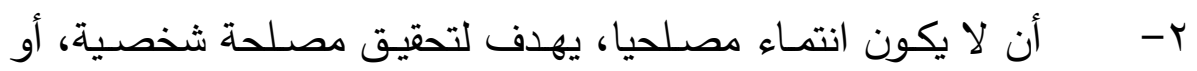

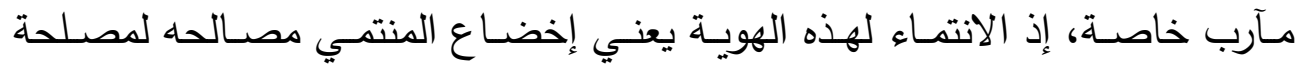

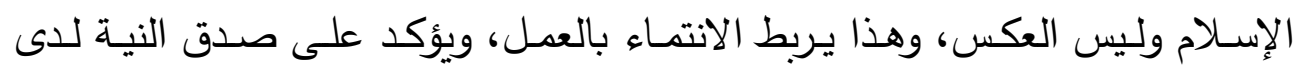

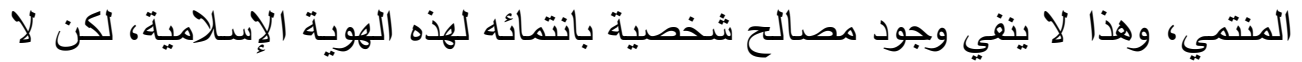

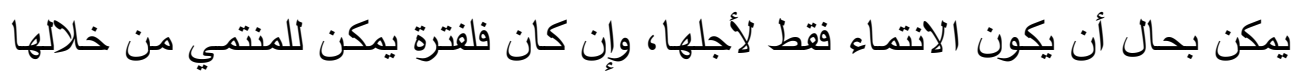

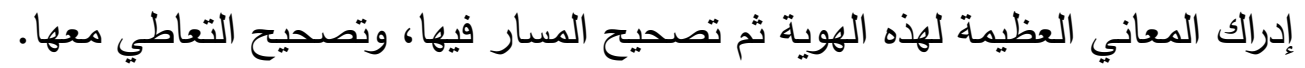

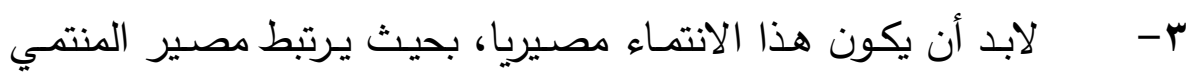
بمصير تلك الهوية، فهو ليس انتماء مرحلة وتتتهي، أو ظرف ويزول، بل هو انتماء

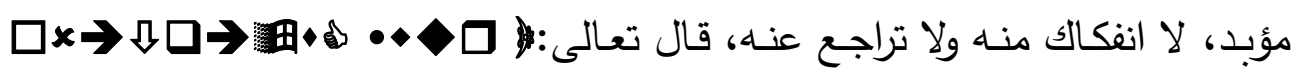
ग (') (1) بمران:

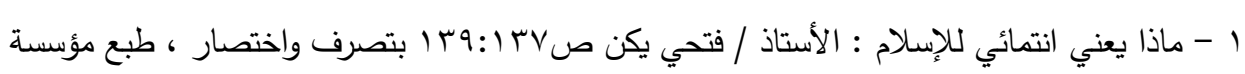

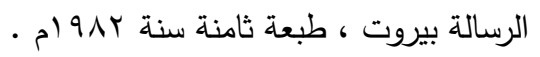


الهوية الإسلامية (روية تأصيلية في ضوء التحديات المعاصرة) 
الهوية الإسلامية (روية تأصيلية في ضوء التحديات المعاصرة)

\author{
الفصل الثاني \\ أهم التحديات التي تواجه الهوية الإسلامية \\ ويشتمل على مبحثين: \\ المبحث الأول: العولمة وأثرها على الهوية الإسلامية. \\ المبحث الثاني: الغزو الفكري وأثره على الهوية الإسلامية.
}




\section{الهوية الإسلامية (روية تأصيلية في ضوء التحديات المعاصرة)}

\section{الفصل الثاني \\ أهم التحديات التي تو اجه الهوية الإسلامية}

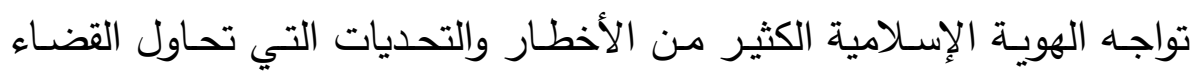

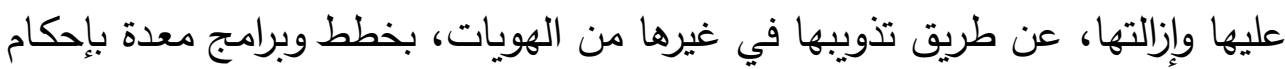

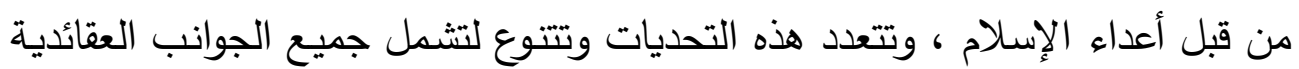

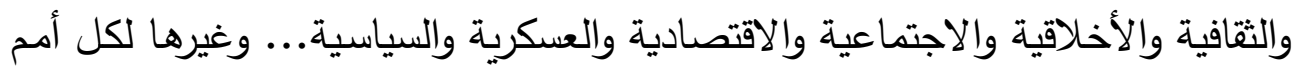

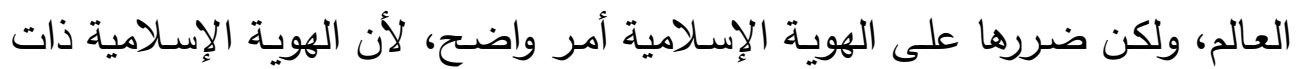

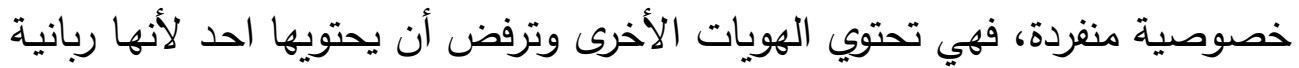

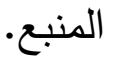

وأهم هذه التحديات: العولمـة، والغزو الفكري، والاستشراق، ووسائل الإعـلام التي تعمل بوقا لنشر أفكار الغرب وتشكل تهديدا خطيرا على الهوية الإسلامية،..... وغيرها.

إن إلزام العالم بأسره بانتهاج نظام سياسي واقتصادي واجتماعي وثقافي واحد،

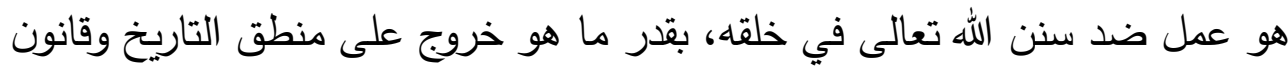

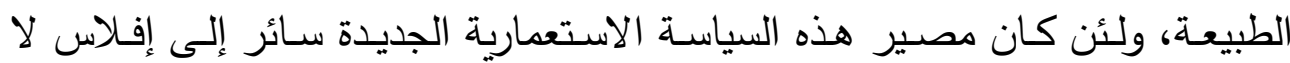

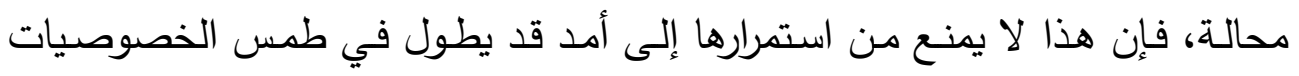

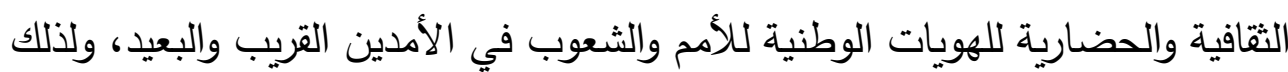

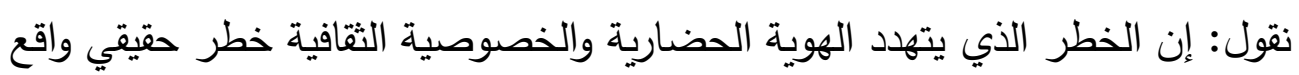

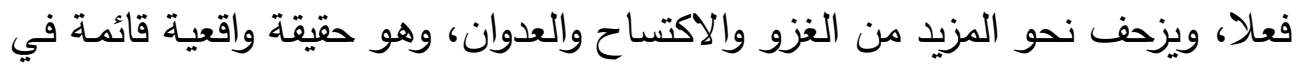

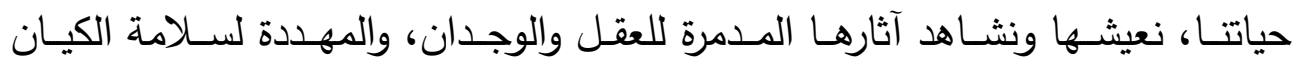

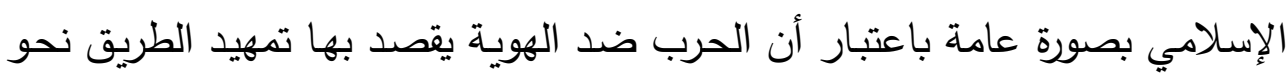




\section{الهوية الإسلامية (روية تأصيلية في ضوء التحديات المعاصرة)}

فرض الهيمنة السياسية والعسكرية والاقتصادية والإعلامية والثقافية ('). إن التحديات التي تواجه هويتنا تضعف المناعة والحصـانة لدى الفرد والمجتمع الإسـلامي، وتؤثر على خصوصيتنا وثقافتنا، وتسبب أزمـة عقدية وأخلاقية، كما أنها تقوم بالتشويش والتشويه لهويتنا، لتؤثر على مواطن القوة والعزة والمنعة في حياتـا، ولتخلق أجيالا مقلدة، مشوهة فاقدة الهوية منبهرة مفتونة بالنموذج الغربي. ومن هنا يشعر المسلم بالانكسار والهزيمة، كما يضعف الانتماء والولاء للهوية. وسـوف نتحدث - بـإذن الله تعـالى - عـن أهـم التحديات التي تواجـه الهويـة الإسلامي، ويقتصر الحديث على العولمة والغزو الفكري. 
الهوية الإسلامية (روية تأصيلية في ضوء التحديات المعاصرة)

$$
\text { العولمة و أثر ها على الهوية الإسلامية المأول }
$$

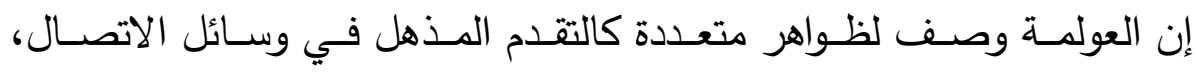

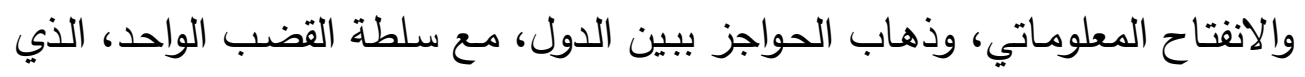
يسعى للهيمنة السياسية والاقتصادية والعسكرية والثقافية.

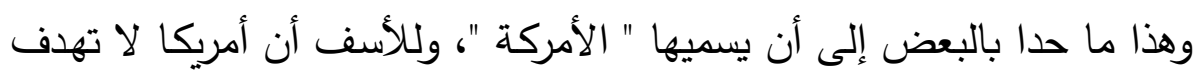

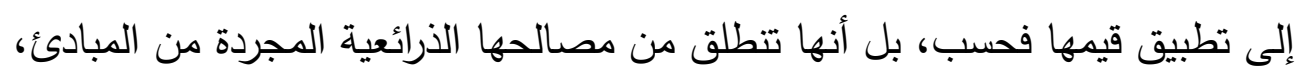

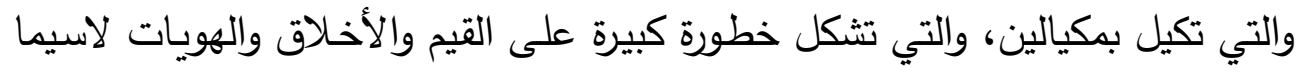
الإنسلامية (') النيكية * أنصار العولمة يصورونها كدين جديد.

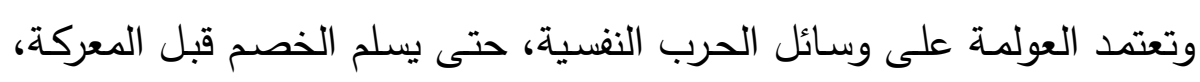

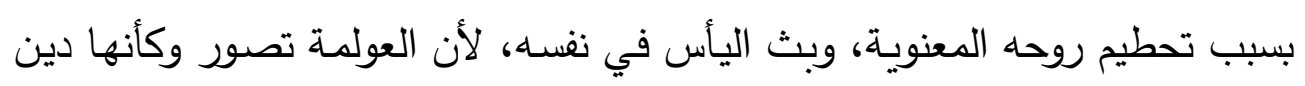
جديد كما يراها

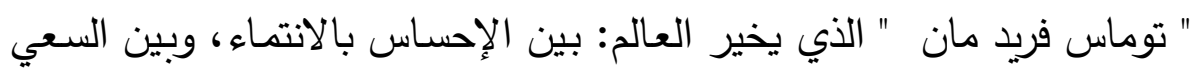

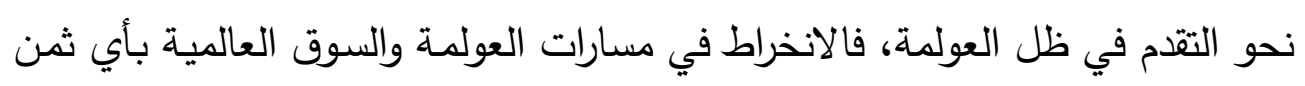

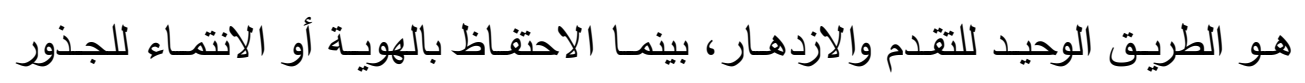
الوطنية والدينية هو طريق التخلف والاندثار (؟). وبذلك تعتمد العولمة بإثاعة فكرتها على عاملين:

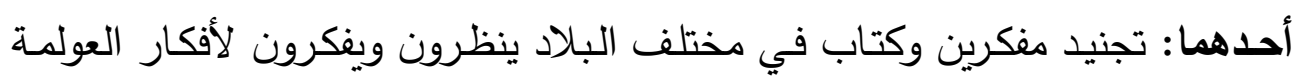
1 ا - العولمة وأثرها على الهوية : د ـ خالد عبد الله القاسم ، موقع الإسلام اليوم الشبكة المعلوماتية www.islamtoday.net/pohoothiartshaw/86/73350

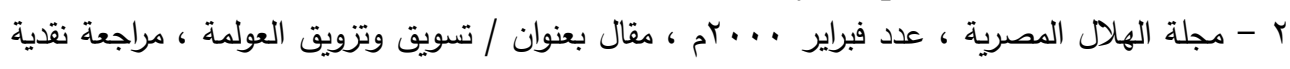

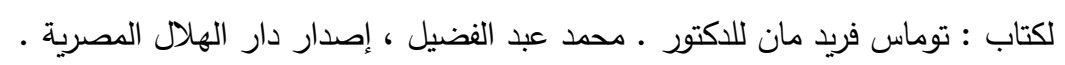




\section{الهوية الإسلامية (روية تأصيلية في ضوء التحديات المعاصرة)}

والكونية، ويؤكدون أن الثعور بالولاء لأمة أو وطن أصبح من مخلفات الماضي(').

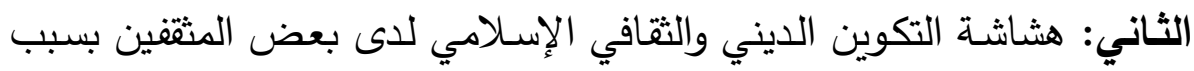

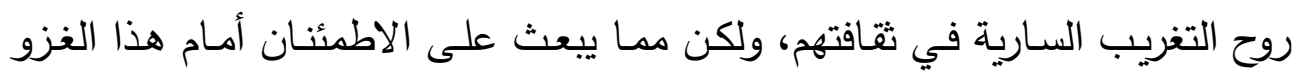
الجديد لثقافتنا أن النغران

( عامة لمسلمين فيهم حصانة روحية وإيمان قوي يجعلهم يميزون بين الخبيث

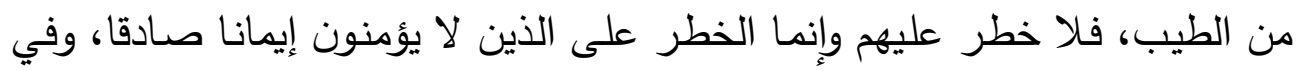
نفوسهم اضطراب واتجاه إلى تقليد الغربيين في كل شيء وتقديس ما عندهم سواء إنهاء

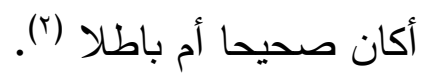

إن العولمسة يجب أن تكون من أجل الإنسان، في العلوم والتقنيات، والتعامل

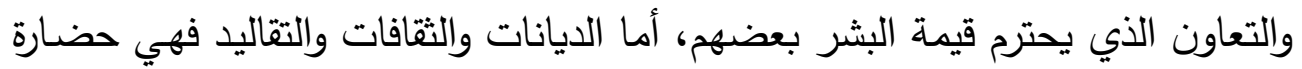

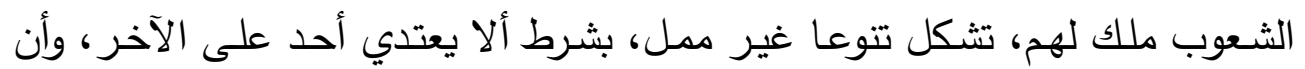

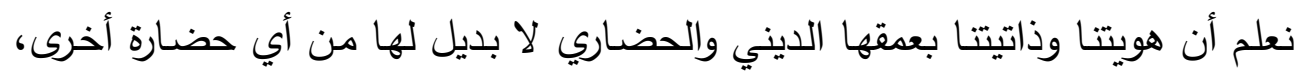

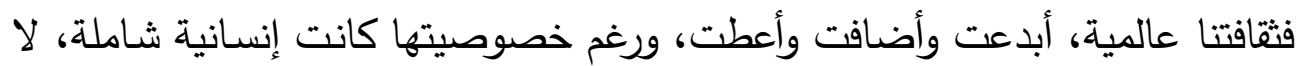
بتراثها الإسـلامي وهو ذروة عطائهـا، ولكن بمـا تجاوزتـهـ مـن عناصـر الحضـارات

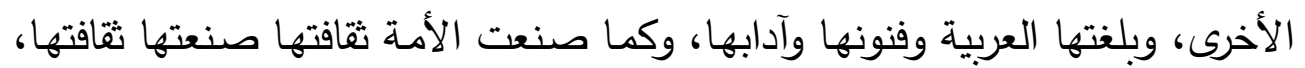

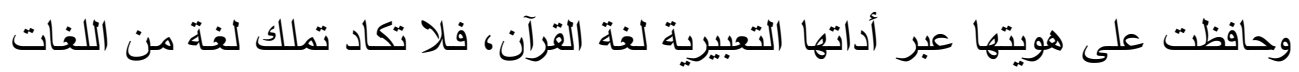

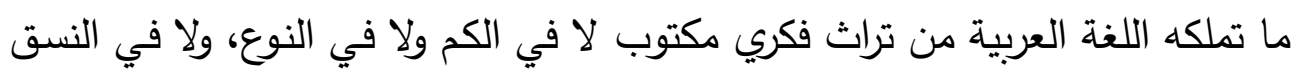

ا - الجات والتبعية الثقافية : د ـ مصطفى عبد الغني ص ا 1 ، طبع الهيئة المصرية العامة للكتاب ، مكتبة

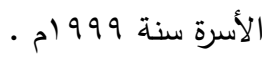

ץ - الإسلام في عصر العولمة ، كتاب المؤتمر الدولي الرابع للفلسفة الإسلامية ، كلية دار العلوم جامعة القاهرة ، بحث بعنوان : كيف نصون الهوية الإسلامية الثقافية في عصر العولمة : د . . مصطفى حلمي

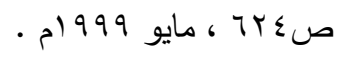


الهوية الإسلامية (روية تأصيلية في ضوء التحديات المعاصرة)

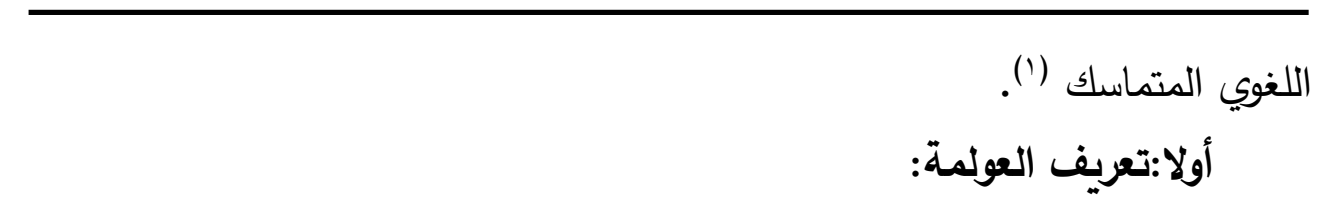

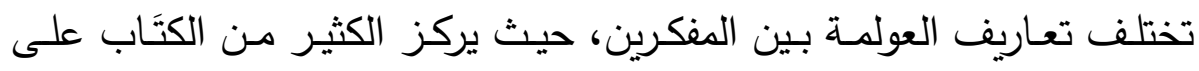

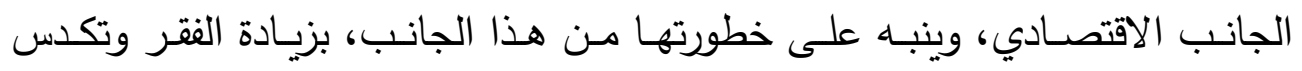

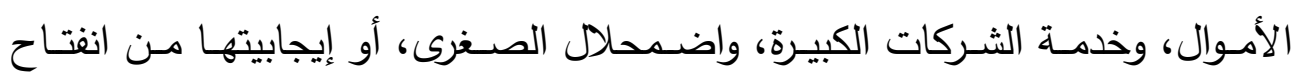

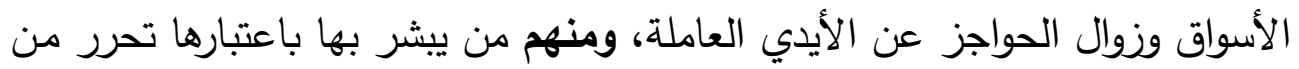

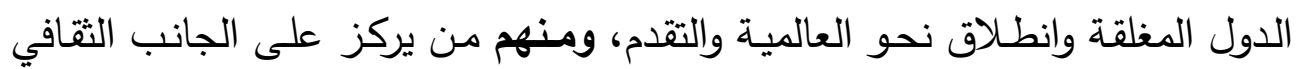
وأضراره، ومنهم من يأخذها بمضمونها الثامل. وهذا الاختلاف بسبب ذكر كل واحد جانبا من الموضوع.

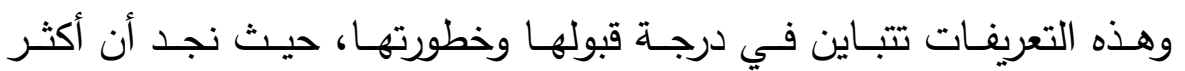
المفكرين المسلمين ينبه على خطورتها، مع التركيز على الجانب الاقتصادي.

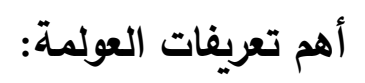
يعرف أحدهم العولمـة بأنها: العولمة هي الاستعمار بثوب جديد، ثوب تشكله

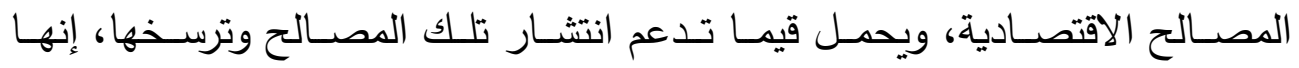
الاستعمار بلا هيمنة سياسية مباشرة، أو مخالب عسكرية واضحة، إنها بكل بساطة الفارة

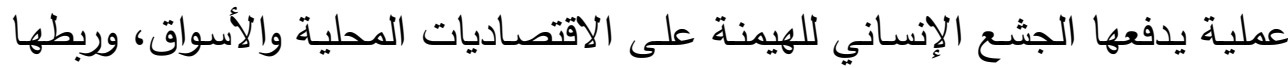
بأنظمة أكبر ، والحصول على أكبر قدر من المستهلكين.

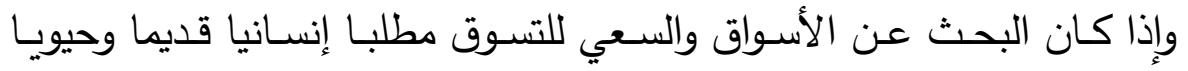

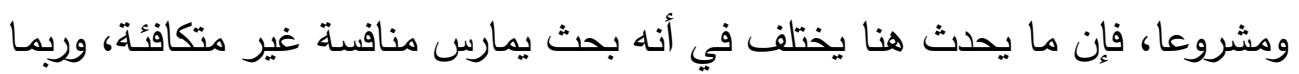

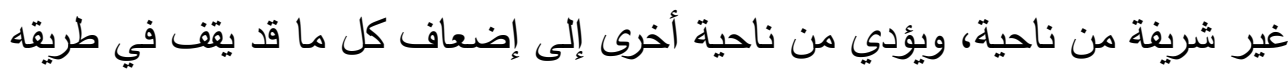

1 - العولمة وقضية الهوية الثقافية في ظل الثقافة العربية المعاصرة : الأستاذ / محمد سعد التميمي

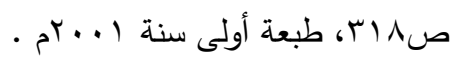
-1 Ar- 


\section{الهوية الإسلامية (روية تأصيلية في ضوء التحديات المعاصرة)}

$$
\text { من قيم وممارسات اقتصادية وثقافية (') }
$$

بينما يركز بعضهم على الجانب الثقافي، ووصفوا العولمة بأنها اختراقا ثقافيا.

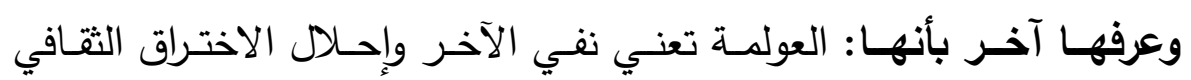

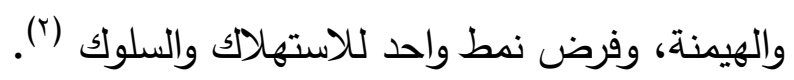

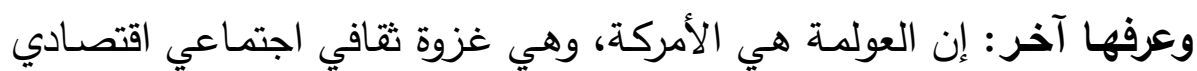

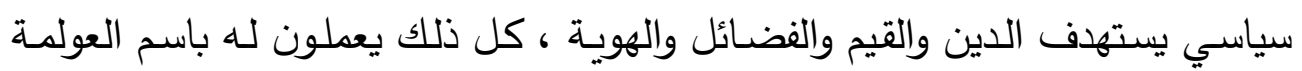
وحقوق الإنسان (r).

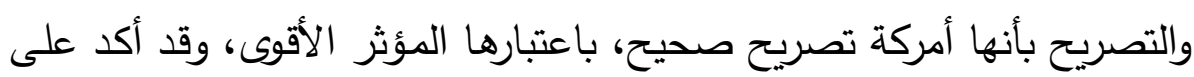

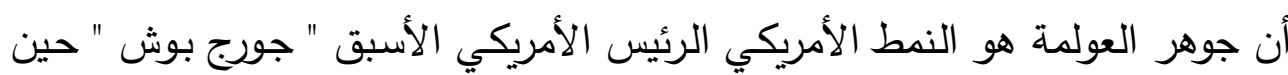

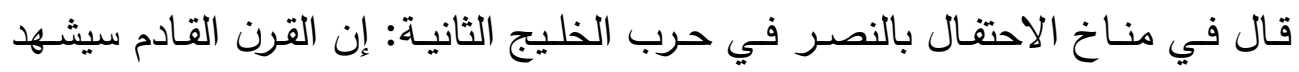

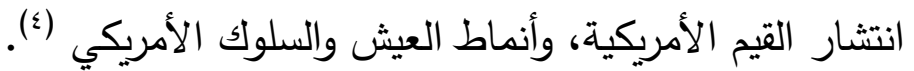
وربما تكون صهينة لاسيما واستثمار اليهود الذين يقودون الغرب وأمريكا تحديدا

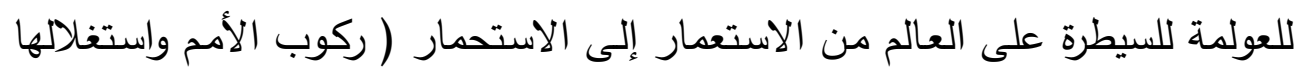
دون القضاء عليها (ْ). وبذلك تكون العولمـة أمريكية ولكنها بزعامـة وقيادة صـهيونية، لإفساد العالم

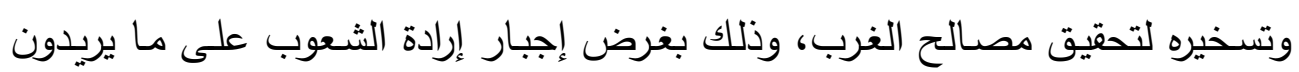
1 - نحن والعولمة من يربي الآخر : سلسلة كتاب المعرفة صبr ، العدد السابع ، طبعة أولى سنة . 1999 r - العولمة وقضية الهوية الثقافية في ظل الثقافة العربية المعاصرة : الأستاذ / محمد سعد التميمي صوج

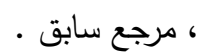

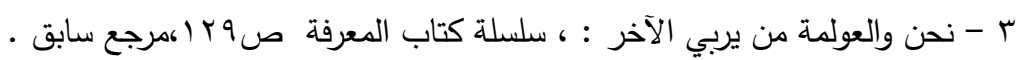

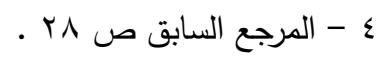

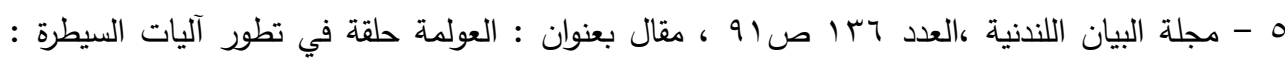

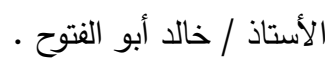


الهوية الإسلامية (روية تأصيلية في ضوء التحديات المعاصرة)

سلما أو حربا.

ثانيا: آثار العولمة على الهوية الإسلامية:

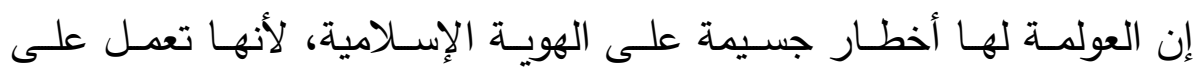

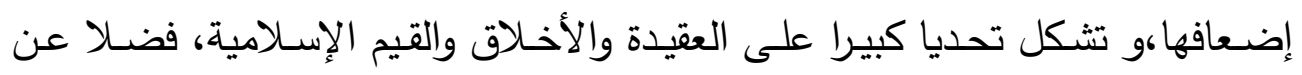

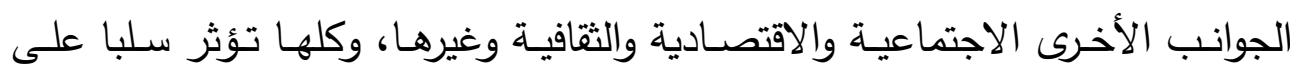
الهوية الإسلامية.

وسوف أذكر بعض هذه الآثار لكثف أمرهـا، ومعرفـة حقيقها، وتثخيص العلاج المناسب لها، وذلك فيما يلي: ( ) أثر العولمة على العقيدة:

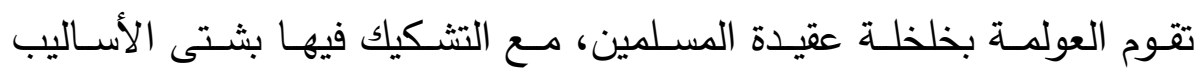
والوسائل لنشر الكفر والإحاد، والتهوين من شأن العقيدة في نفوس أصحابها.

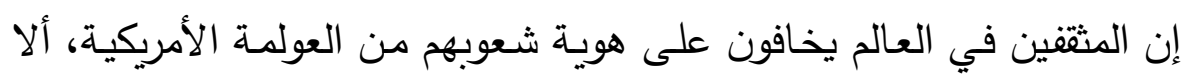

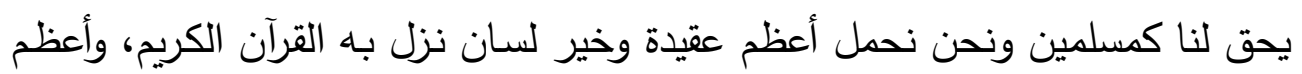

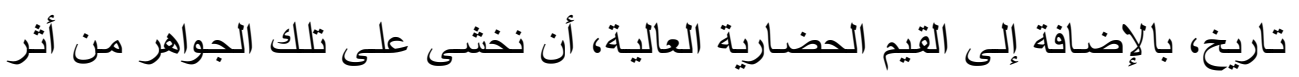

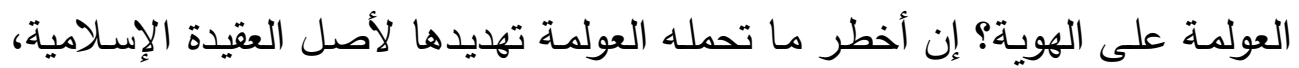

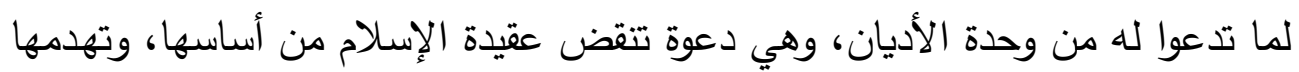

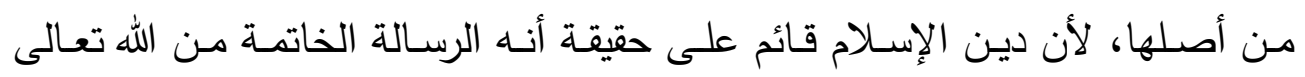

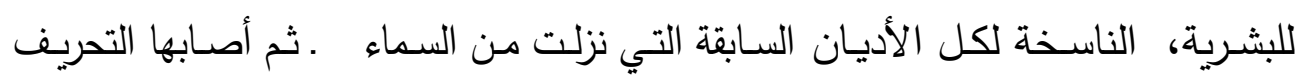
والتغيير - ودخل على أتباعها الانحراف العقائدي.

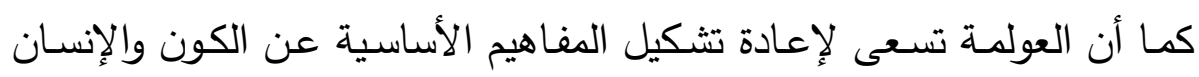
والحياة عند المسلمين، والاستعاضة عنها بالمفاهيم التي يروج لها الغرب ثقافيا وفكريا،

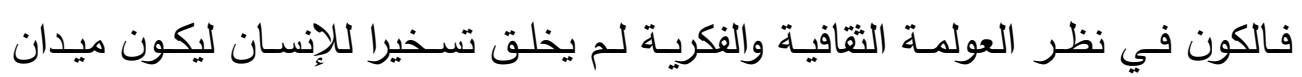
امتحان للناس لابتلائهم أيهم أحسن عملا، والإنسان لم يخلق بهدف عبادة الله تعالى، 


\section{الهوية الإسلامية (روية تأصيلية في ضوء التحديات المعاصرة)}

وهذه المفاهيم الأساسية للعقيدة الإسـامية ليست في نظر العولمـة الثقافيـة والفكريـة سوى خرافة (').

إن هـذه العولمـة لا تعـرف إلا العـالم المـادي المحسـوس، والحقيقـة الماديـة

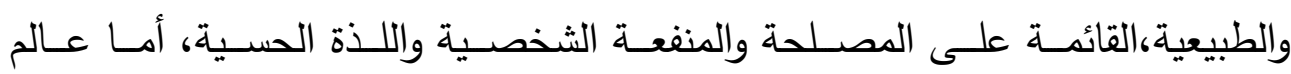
الروحانيات، والمعان الروحية فهي أبعد ما تكون عنها.

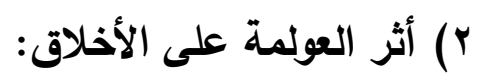

وكما أن للعولمـة آثارا سلبية خطيرة على الملى العقيدة، فهي كذلك لها تأثير سلبي

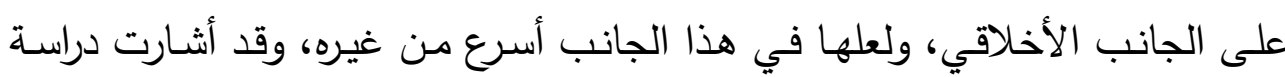

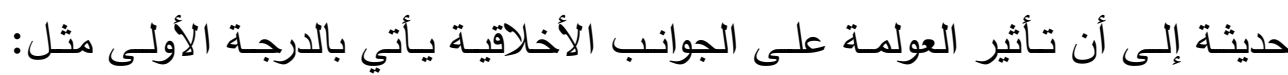

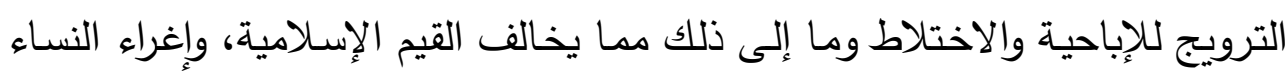

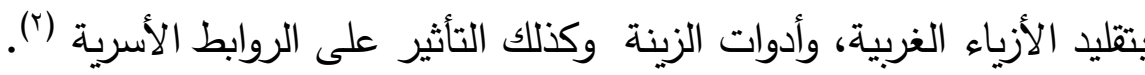

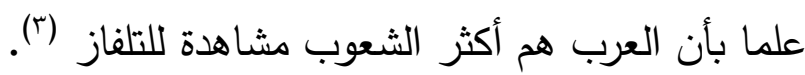

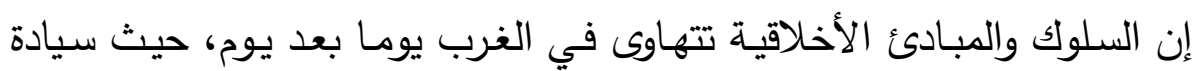

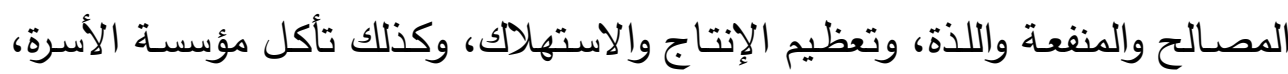
وانتشار الإيدز والمخدرات، وتراكم أسلحة الدمار الكوني والأزمة البيئية، وتزايد اغتراب والابتهاب

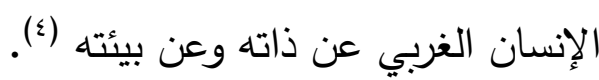

1 - العولمة وقضية الهوية الثقافية في ظل الثقافة العربية المعاصرة : الأستاذ / محمد سعد التميمي

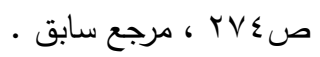

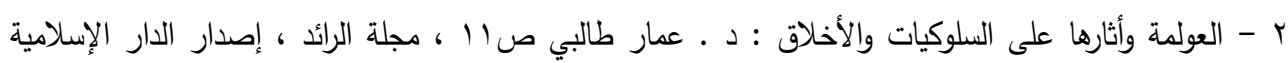

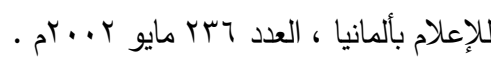

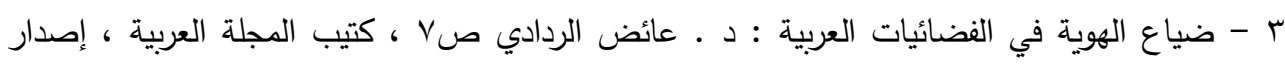

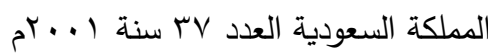

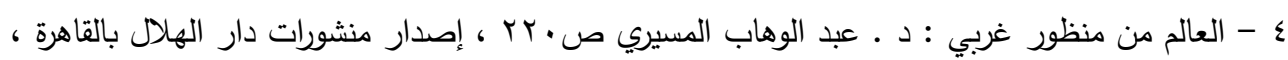

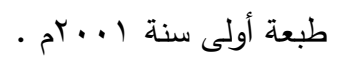




\section{الهوية الإسلامية (روية تأصيلية في ضوء التحديات المعاصرة)}

وكل هذه السلبيات تصدرها العولمة إلى الدول العربية والإسلامية، كما تسوق

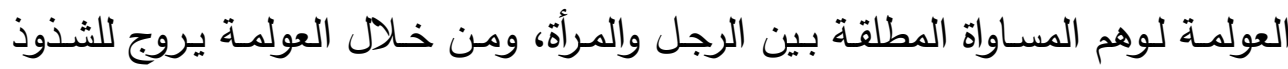
الجنسي، ويحاول الغرب استصدار قوانين لحماية الثذوذ الجنسي في العالم، ومن الثن

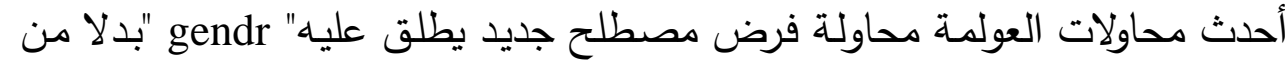

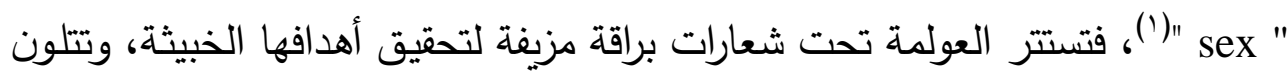

$$
\begin{aligned}
& \text { لتنطلي على السذج و وتخدع السفهاء. }
\end{aligned}
$$

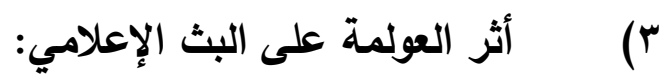

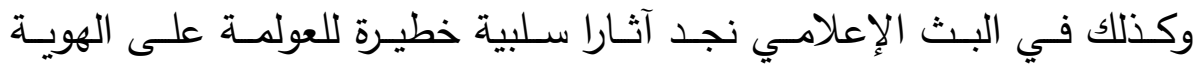

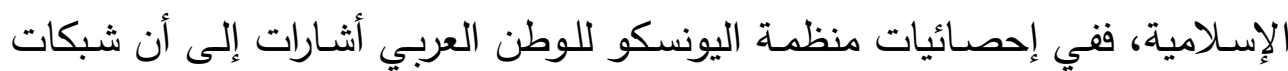

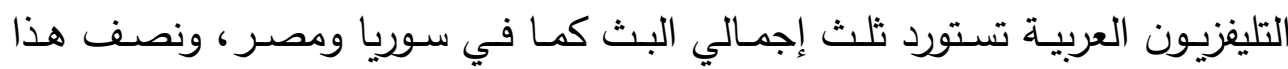

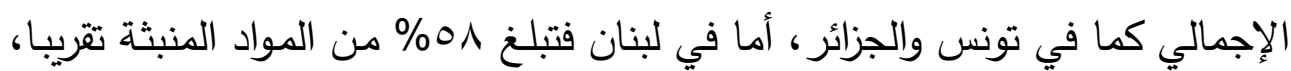

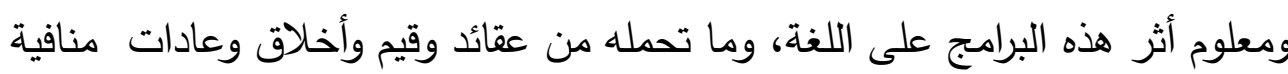

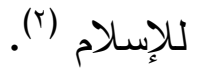

\section{؛ ) أثر العولمة علي اللغة العربية:}

وذلك بالترويج لتعليم ونشر اللغة الإنجليزية، والدعوة إلى العامية، والقضاء على التى الته

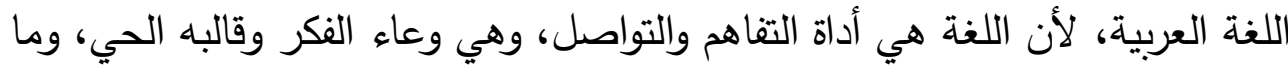
نراه اليوم يمثل طغيان الثقافة الغربية، حيث تمثل اللغة نسبة عالية من الإسهام في

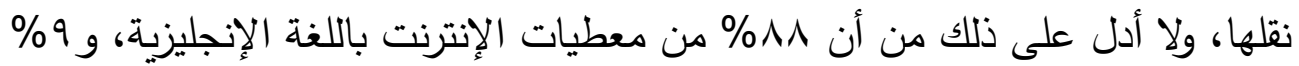

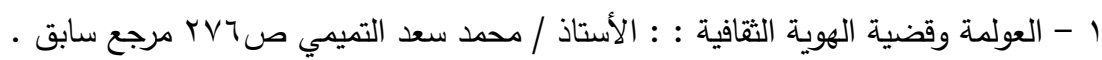

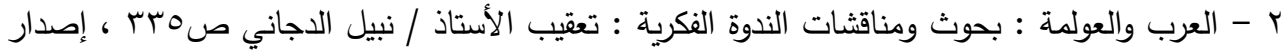
مركز دراسات الوحدة العربية ، طبعة ثانية سنة 991 الع. 
الهوية الإسلامية (روية تأصيلية في ضوء التحديات المعاصرة)

بالألمانية، و †\% بالفرنسية، و ا \% يوزع على باقي اللغات (') أضف إلى ذلك الترويج

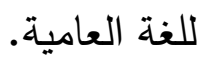

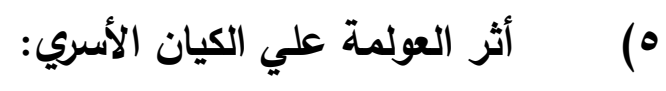

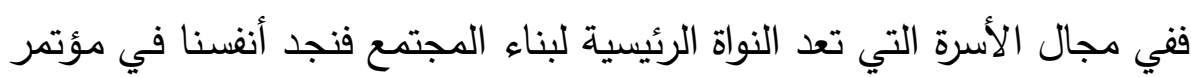

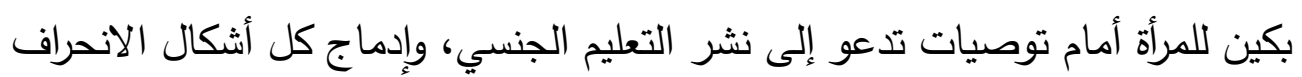

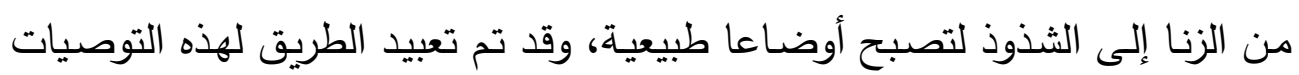

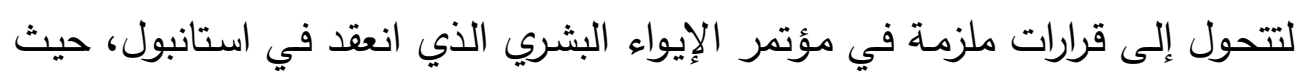

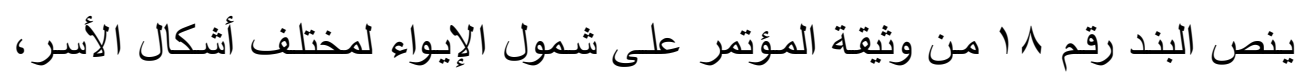
والمقصود من ذلك منح الثاذين جنسيا الذين يكونون فيما بينهم أسرا، وتلك الأشكال

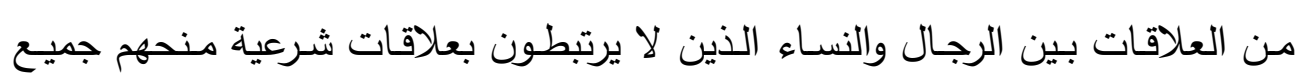

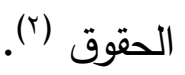

ثالثاً :كيف نواجه آثار العولمة على الهوية الإسلامية في العصر الحاضر؟:

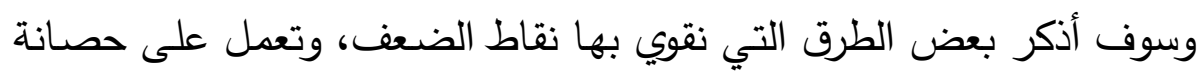

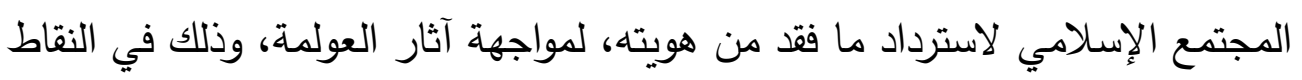

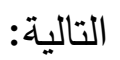

1- - تعزيز الهوية بأقوى عناصرها، وهو العودة إلى الإسلام، وتربية الأمة

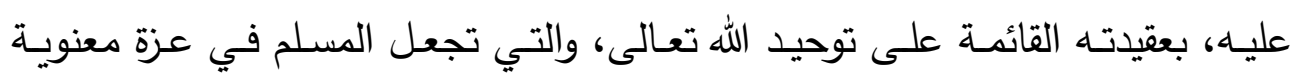

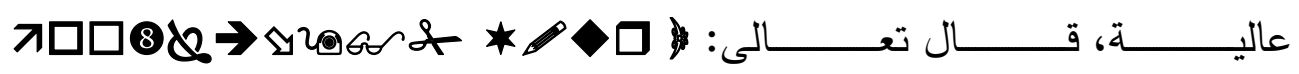

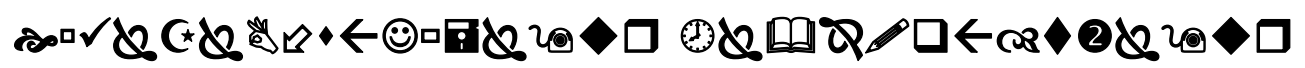

1 - العولمة وقضية الهوية الثقافية في ظل الثقافة العببية المعاصرة : الأستاذ محمد سعد التميمي صل11

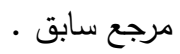
r - أثر العولمة على الهوية : الأستاذ / محمد صديق ، مقال على شبكة المعلومات الدولية على الموقع : http//www.shareah.com/hdex.php?/records/list/id/1/ 
الهوية الإسلامية (روية تأصيلية في ضوء التحديات المعاصرة)

(المنافقون من الآية: ^. وبشريعته السمحة وبأخلاقه الروحية وتقوية الصلة بالله تعالى، واليقين بنصره وتمكينه للمؤمنين. ץ- العناية باللغة العربية في وسائل الإعلام، ومناهج التعليم، وتسهيل تدريسها وتحبيبها للطلاب.

r- إبـراز إيجابيـات الإســلام وعالميتــه، وعدالتـه وحضـارته وتقافتـه وتاريخـهـ للمسلمين قبل غيرهم، ليستلهموا أمجادهم ويعتزوا بهويتهم. يقول الأستاذ / محمد قطب:

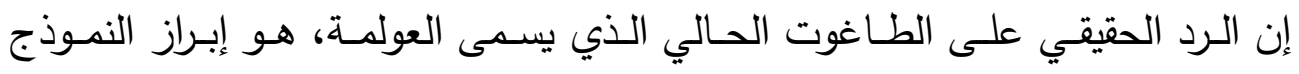

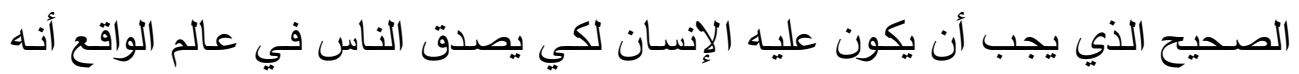

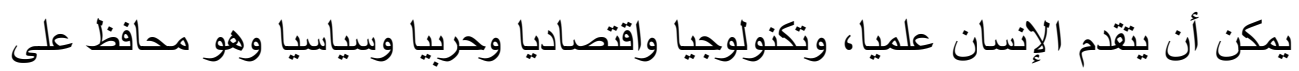

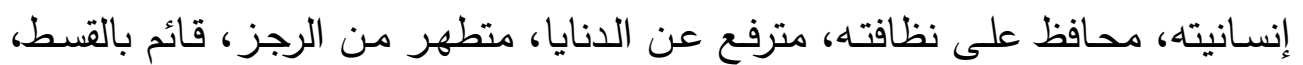

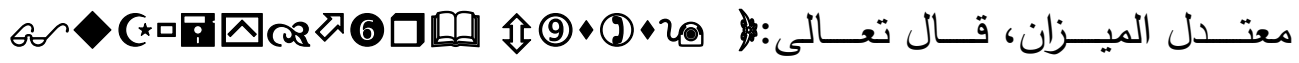

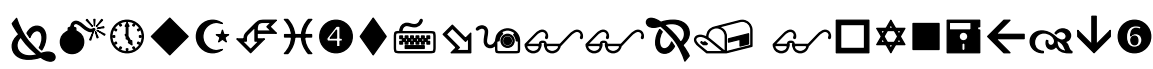

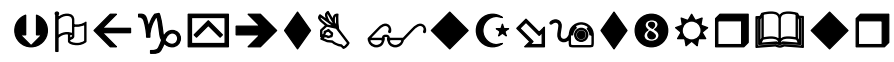

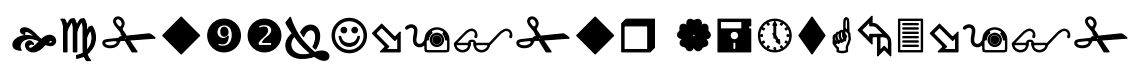

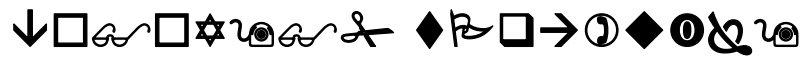
(') ب الحديد الآية: ع - العمل على نهوض الأمة الإسلامية في شتى الميادين:

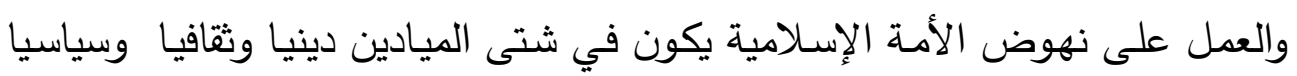

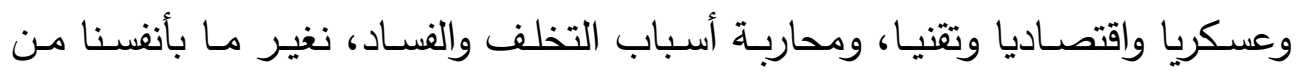


الهوية الإسلامية (روية تأصيلية في ضوء التحديات المعاصرة)

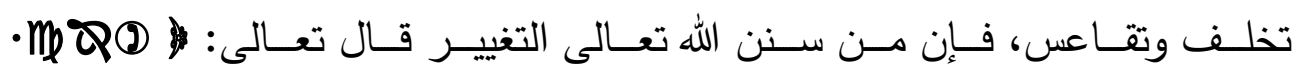

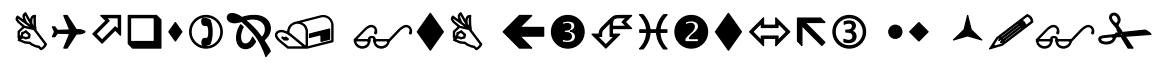

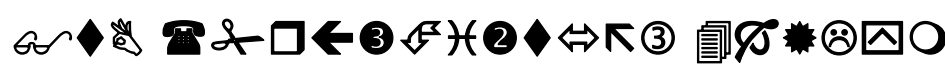
. 11: الرعد من الآية

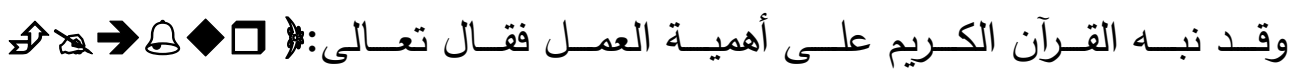

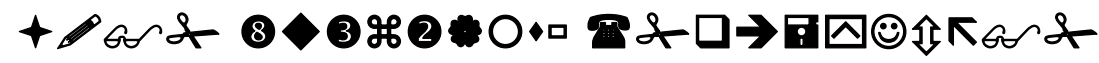

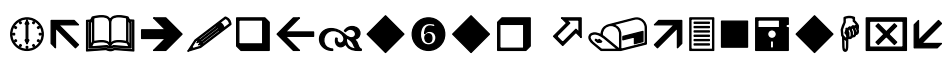

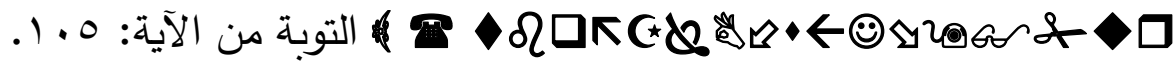

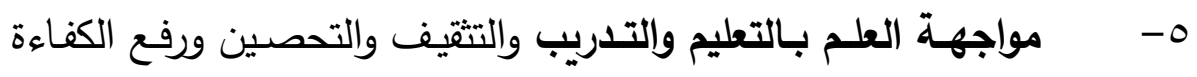
وزيادة الإنتاج ومحاربة الجهل، و خفض معدلات الأمية المرتفعة عند المسلمين.

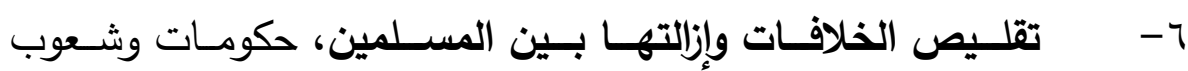
وجماعات، وذلك :

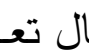
(1)

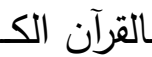
بالاعتص

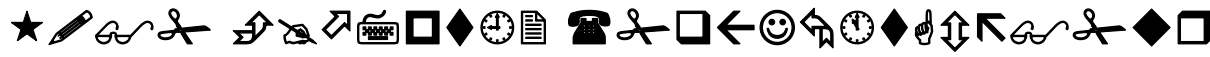

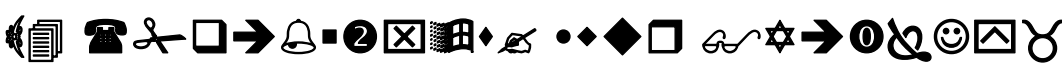
ثم التعامل معها،إن وجدت بثقافة إيجابية واعية ناصحة،بالحوار الأخوي الهادئ البناء حتى لا يجد الأعداء ثغرة يبثون سمومهم من خلالها.

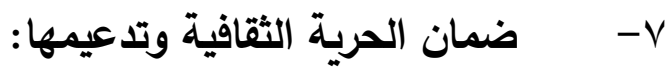

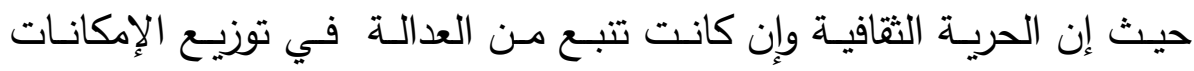

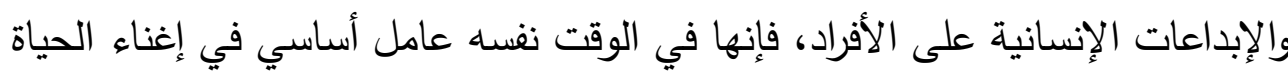

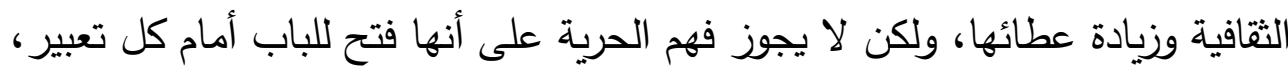




\section{الهوية الإسلامية (روئة تأصيلية في ضوء التحديات المعاصرة)}

وقبول كل فكر ، ولكن الحرية المقصودة هي الحرية المنضبطة بضوابط الشرع (').

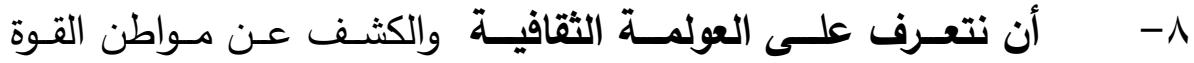
والضعف فيها، ودراسـة سلبياتها وإيجابيتها برؤيـة إسـلامية وإدراك وفهم المتناقضـات

التي تكتنف فكرة العولمة، وكثف الزيف التي تستتر قواها خلفه (؟). 9- - التنسيق والتعاون بصورة متكاملة بين وزارات التربية والتعليم والتعليم العالي والثقافة والإعلام والأوقاف والعدل، للمحافظة على الهويـة الإسـامية من أي لئي

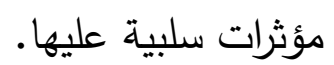
• - - أن تقوم وسـائل الإعلام بواجباتها للمحافظـة على الهوية ودعمها،

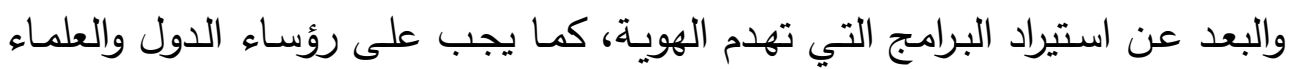

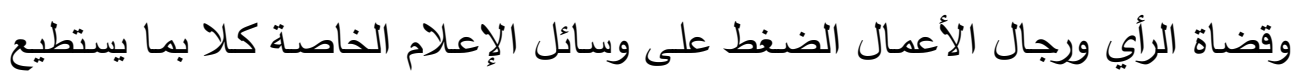
لمراعاة هوية الأمة وقيمها. 1) - أن يقوم التعليم بتعزيز الهويـة، وكثف العولمـة ومضارها، ويتحتم على الإسـلام التربوي استخدام كافة الوسائل والطرق المتاحة كي ينجح في تأصيل وكيل ولئل

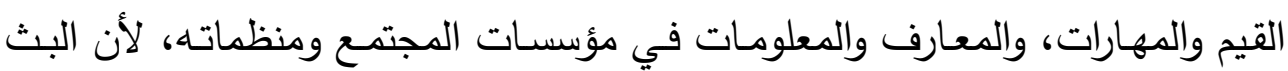

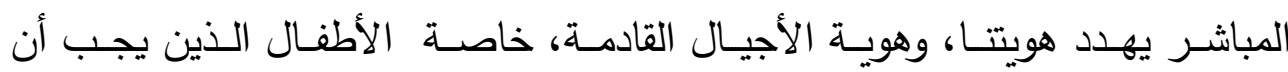

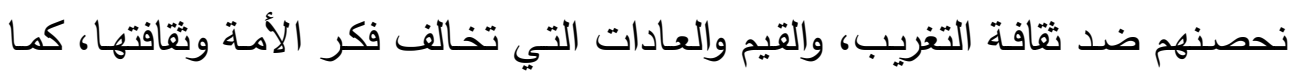

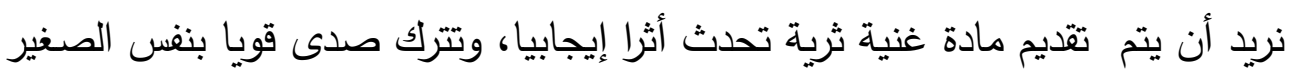
والكبير ، والطالب والثاب، وتساعد على اكتثاف ما يملك من طاقات ومهارات (†).

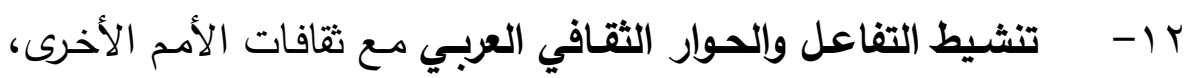

| - العولمة وقضية الهوية الثقافية : الأستاذ / محمد سعد التميمي ص ب ب ب مرجع سابق .

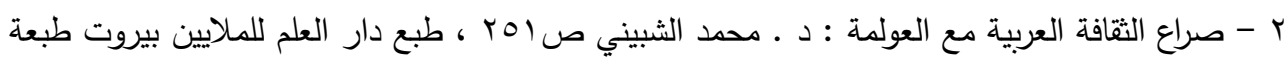

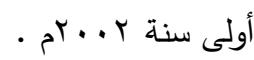
r - مسئولية الإعلام في تأكيد الهوية الثقافية : د ـ أسعد العرابي الحارثي ص •ـ ، المجلة العربية . 


\section{الهوية الإسلامية (روية تأصيلية في ضوء التحديات المعاصرة)}

وأن نثري ثقافتنا العربية الإسلامية بما نراه ينفعنا ولا يضرنا من الثقافات الأخرى، وفي نفس الوقت نعرف الثقافات العالمية بما لنا من تراث وتقاليد وقيم اجتماعية عريقة.

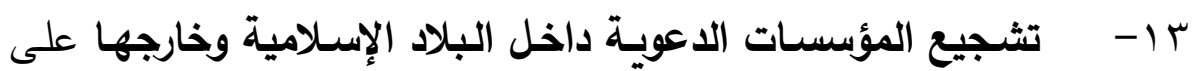

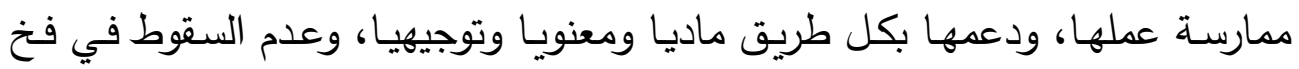

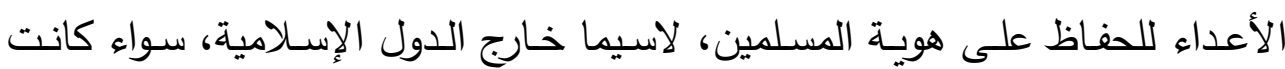
مراكز أو مدارس إسلامية،أو وسائل إعلامية كمواقع الإنترنت، لتحصينهم ضد الأثيرات لإن التهات

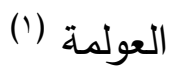

\section{رابعا: نماذج واقعية من سلبيات العولمة على الهوية الإسلامية:}

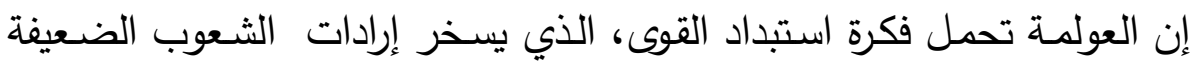

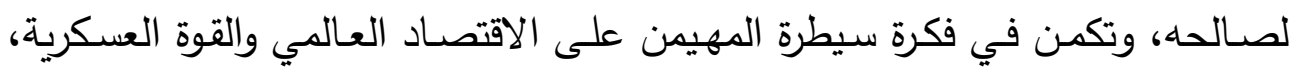

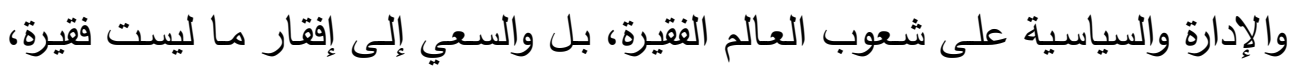

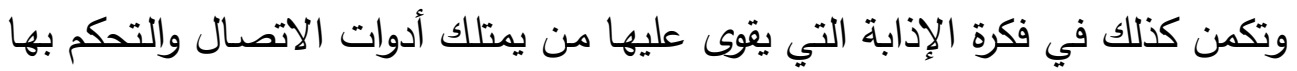

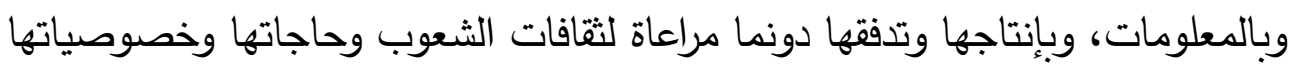

وإمكاناتها (r)

كما أن مما يزيد خطورة العولمة ذراعها الإعلامي الخاضع للسيطرة الصهيونية

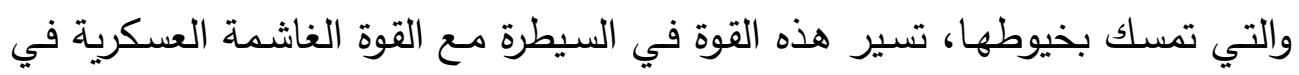

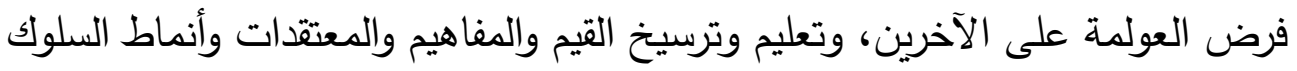

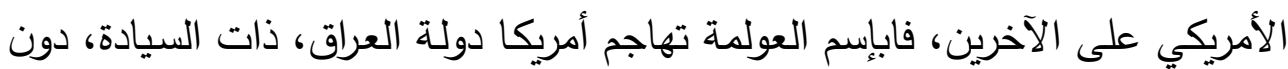

1 - العولمة الثقافية وأثرها على الهوية : د ـ خالد عبد الله القاسم صع (، جامعة الملك سعود بالرياض سنة

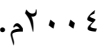
r - العولمة والهوية : المؤتمر العلمي الرابع لكلية الآداب والفنون ، كلمة عميد الكلية :د . صالح أبو ضلع

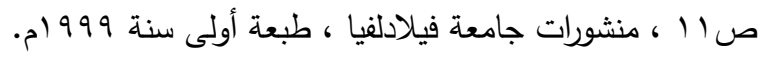




\section{الهوية الإسلامية (روية تأصيلية في ضوء التحديات المعاصرة)}

إذن من الأمم المتحدة، بشبهة أسلحة الدمار الثامل، في حين تترك دولة قريبة منها

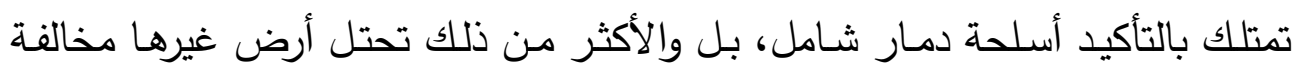

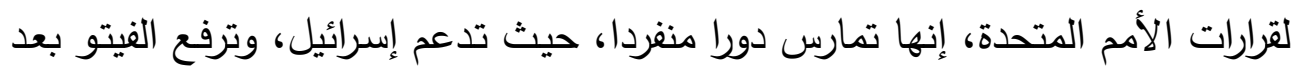

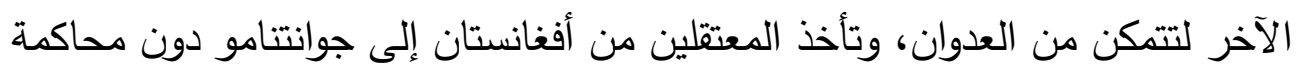

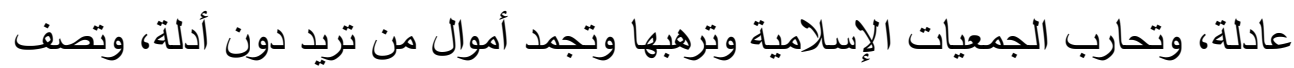

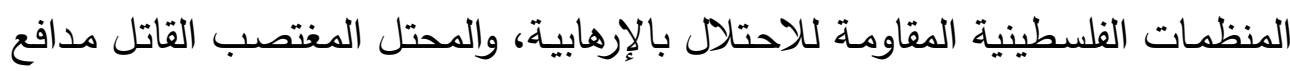
عن نفسه، والجماعات الإسلامية في أفغانستان المقاومة للاحتلال الأمريكي وحكومته بالإهابه

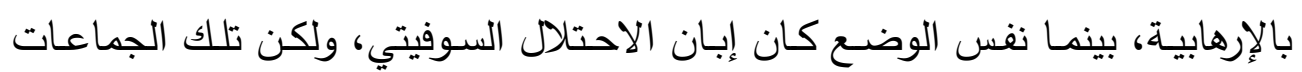

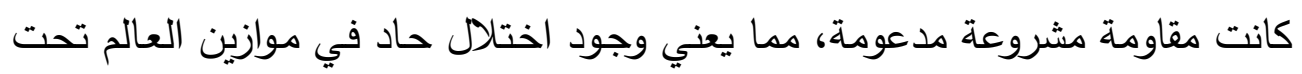
إمرة الحضارة الغربية الصليبية الصهيونية.

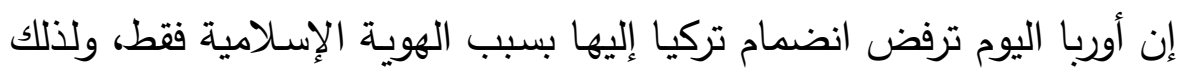

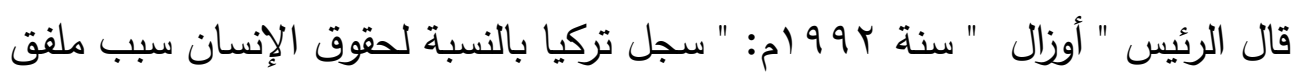

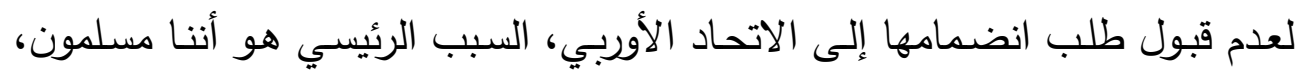

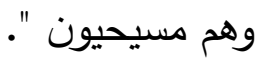

فالقواد الأوربيون يظهرون صراحة أنهم لا يريدون دولة إسلامية مثل تركيا في الاتحاد الأوربي، ولا يسعدهم أن تكون دولة إسلامية أخرى " البوسنة "في قلب أوربا.

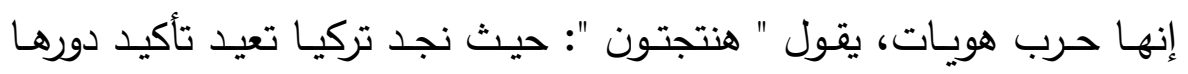

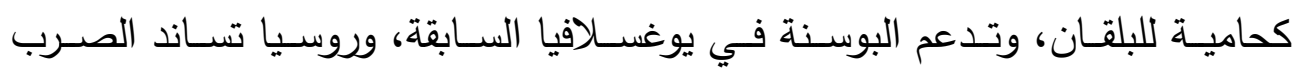
الأرثوذوكسية، وألمانيا تساعد كرواتيا الكاثوليكية ، والدول الإسـلامية تهرع لمسياعدة الحكومة البوسنية، الصرب يحاربون الكروات ومسلمي البوسنة ومسلمي ألبانيا وهذا يؤكد أنها صراع هويات.

وفي حين يحرم الشيشان من الانفصال عن روسيا، ويجبر أهل تيمور على هلى 


\section{الهوية الإسلامية (روية تأصيلية في ضوء التحديات المعاصرة)}

الانفصال من أند ونسيا بتدخل من استراليا، ودعم من الغرب، وكذلك تتفصل تماما دول البلطيق وجورجيا من روسيا، بينما الدول الإسلامية فاستقلالها غير كامل.

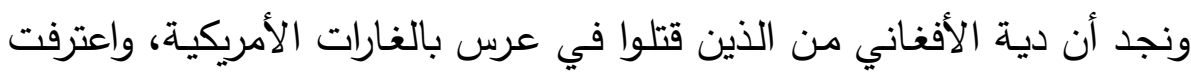

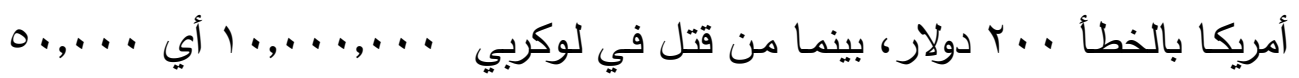

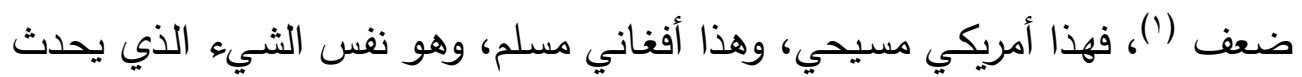

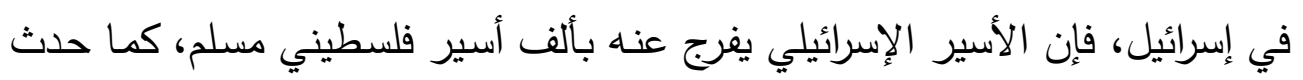

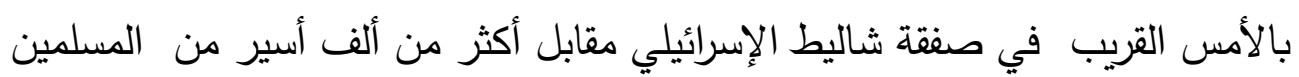
المجاهدين الفلسطينيين في العصر الحاضر.

1 - صدام الحضارات إعادة صنع النظام العالمي : تأليف صموئيل صامويل صع . ب ، مرجع سابق • 
الهوية الإسلامية (روية تأصيلية في ضوء التحديات المعاصرة)

$$
\text { الغزو الفكري وأثره على الهوية الإسلامية الثبانية }
$$

لقد حاول أعداء الإسلام القضاء على الهوية الإسلامية بشتى الوسائل الحربية

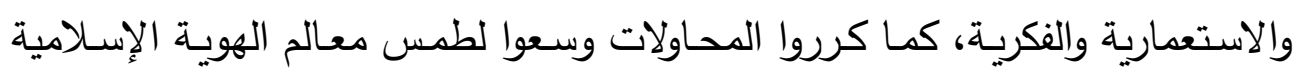
وتشويهها وتغيير معالمها، بحيث يختلط الأمر على أبناء وأجيال المسلمين.

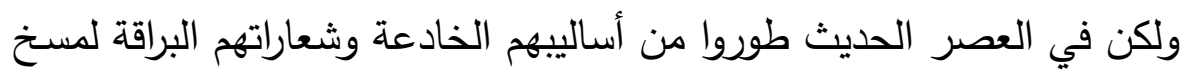
الهوية، والعدوان على الفكر والثقافة الإسلامية.

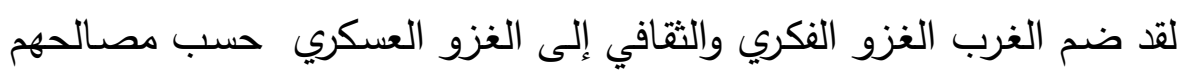

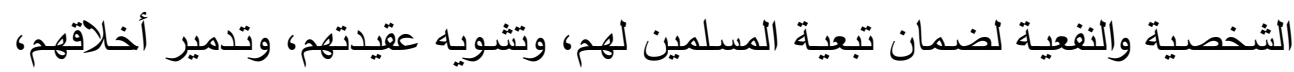
وتركهم نسخ مشوهة قابلة للذوبان في الآخر .

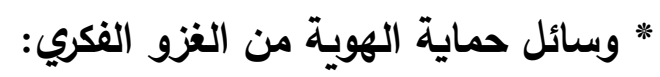

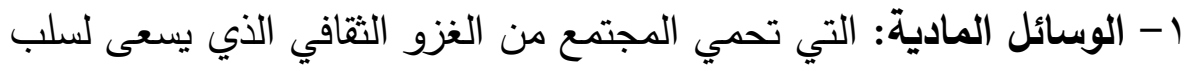

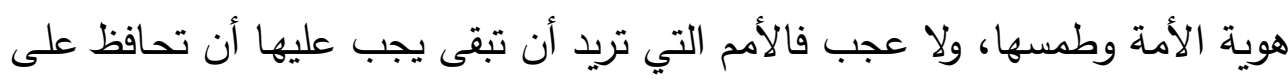

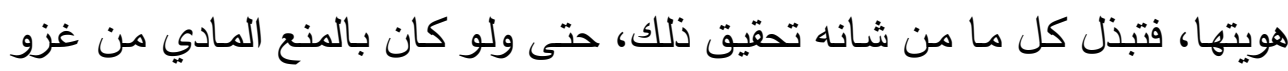
الثقافات الأخرى في أطر محددة ومنضبطة، بحيث لان لا تحدث في الواقع مشكلة أخرى

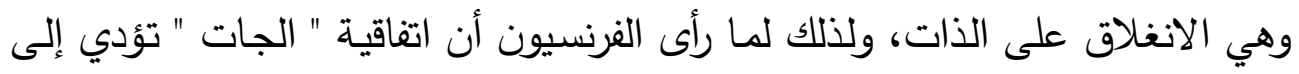

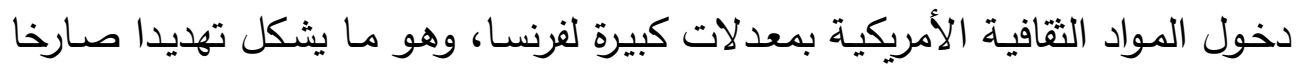

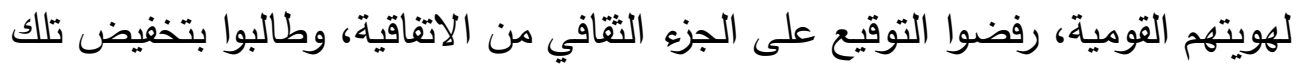

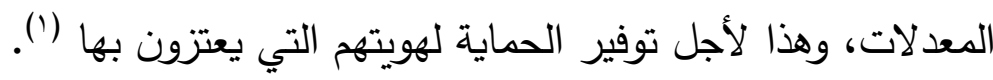

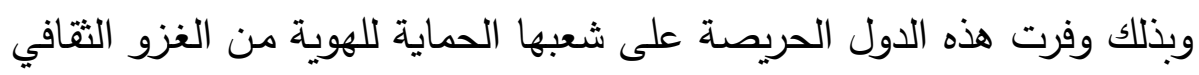

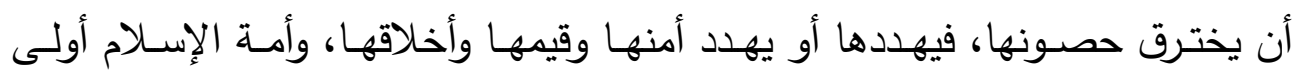
1 - صراع الهويات وخصائص الهوية الإسلامية ، موقع الثبكة الإسلامية ( إسلام ويب ) www.islamweb.com 


\section{الهوية الإسلامية (روية تأصيلية في ضوء التحديات المعاصرة)}

بذلك.

ولا شك أن هذه الخطوة مهمـة للغايـة في توفير الحمايـة للمجتمـع والأمسة مـن أخطار الغزو الفكري والثتافي، وقد لا تكون هي الخطوة الأولى ولكنها خطوة مهمة في مجال الحمايـة والدفاع عن الهويـة الذاتيـة، لاسيما مـع فئـات من أبنـاء المجتمع الذين لابد لهم من هذه الطريقة، وهم العوام الذين لا يملكون معرفة بهويتهم مما يجعل انحرافهم عنها مؤكدا إذا ما تعرضوا لثيء ولو قليل من الغزو الثقافي، ومن المهم هنا التأكيد على التفريق بين الانغـلاق التام والانكفـاء على الذات، بين الاستفادة مـن الثقافات الأخرى بأخذ النافع فيها وتجنب الضـار ، وكذا التثريق بين المعارف العامـة والثقافـة المتعلقـة بهويـة الأمـة والمنعكسـة على سلوك أفرادهـا، وبين العلوم التطبيقيـة الدنيوية التي تعد تجارب بشرية وخبرات إنسانية ترك الله تعالى للبشر تنميتها والترقي فيها بخلاف الهداية الإلهية في العقيدة والشريعة والأخلاق والحكم فهي من الله وحده

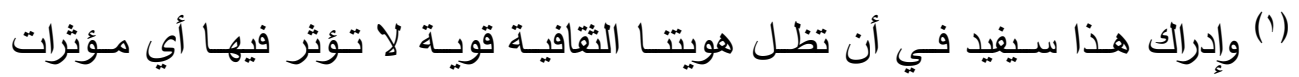

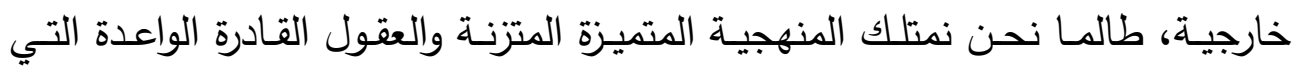
تستطيع أن تحتك بالثقافات الأخرى وتتفتح عليها لتنهل من منابعها الصـافية وتبتعد

ولا تقترب من مياهها العكرة (r).

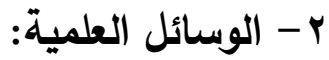

وهي عبارة عن تقديم رؤى نقديـة للأفكار والنظريـات المعاديـة للإسـلام، والتي تحـاول أن تــال مـن الهويـة الإسـلامية، وكذلك حل الإشـكالات الفكريـة التي يثيرهـا خصوم الهويـة بروح علمية مقنعـة، تتجنب الإغراق العاطفي، ليتسلح الثباب المسلم

1 - معالم الثخصية الإسلامية : د ـ عمر سليمان الأشقرصVY r ، طبع دار النفائس للنشر والتوزيع الأردن ، طبعة سابعة سنة ... بام . r - الهنهج التربوي العالمي : د ـ ـ مجدي عزيز إبراهيم ، صسبة ، طبع مكتبة الانجلو الهصرية طبعة أولى

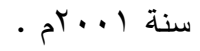




\section{الهوية الإسلامية (روية تأصيلية في ضوء التحديات المعاصرة)}

بالوعي الثقافي، فيمتلكون الأسس والقواعد الثقافية الإسلامية، ويكونوا على درجة كافية

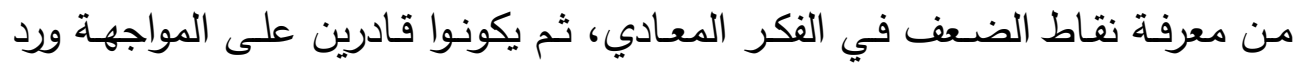

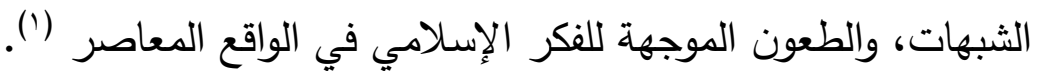

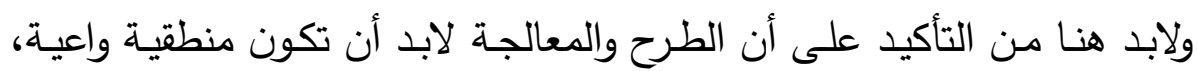

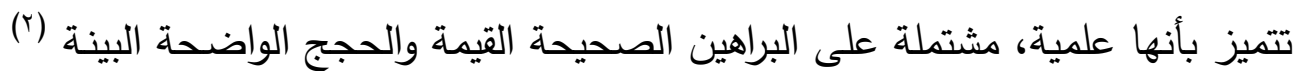

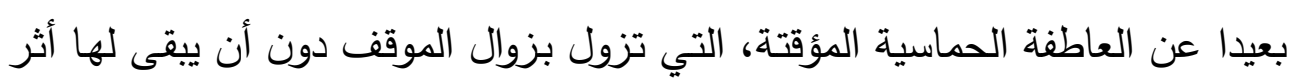

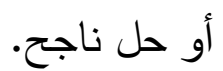

ولذلك يجب على المسلمين الاعتزاز بهويتهم، والقناعة الكاملة بأن ما لديهم لا

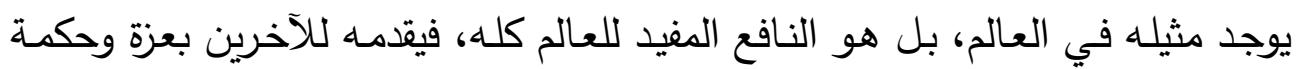
مخاطبا الناس على قدر عقولهم. r- تقديم الهوية الإسلامية للآخرين:

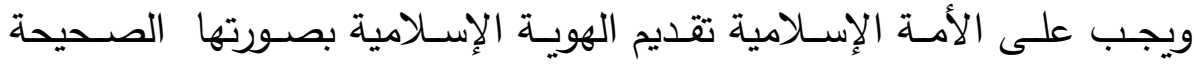
للآخرين، والتعريف بها على حقيقتها وأن لا ينتظر حتى يقدمها أعداؤها بشكل يسيء الأبه

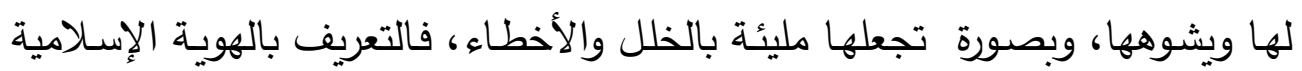

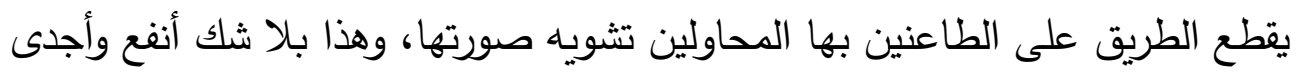

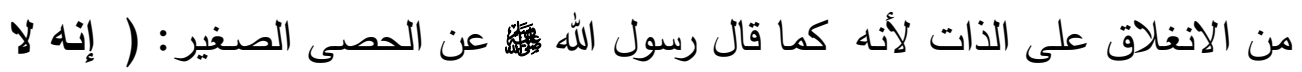
ينكأ العدو، ولا يقتل الصيد، ولكنه يكسر السن، ويفقأ العين)(").

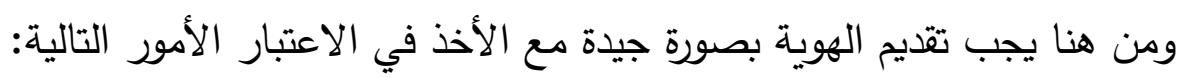

www.balagh.com/matboat/osrh/02/ - 1

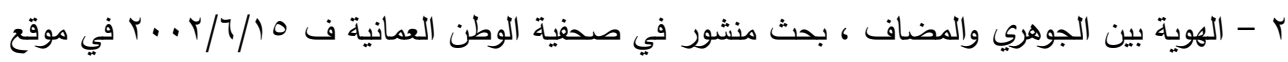
الجريدة www.alwatn.com r - صحيح مسلم ، كتاب : الصيد والذبائح ، باب : ما يستعان به على الاصطياد والعدو ، حديث رقم : .$r V \cdot r$ 


\section{الهوية الإسلامية (روية تأصيلية في ضوء التحديات المعاصرة)}

أ- الاعتزاز بهويتنا الإسلامية ووجود القناعة الكاملة بأن لدينا ما يفيد العالم وما

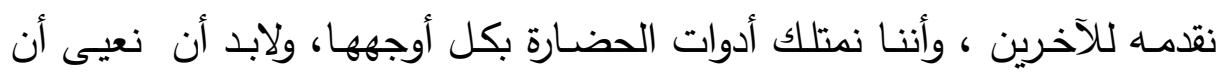
فاقد الشيء لا يعطيه.

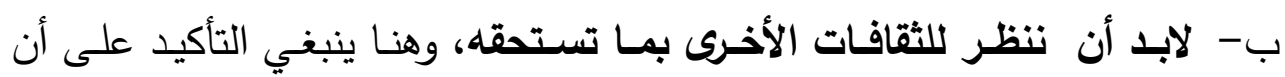

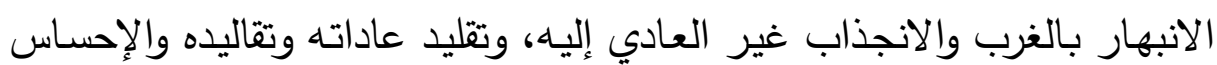

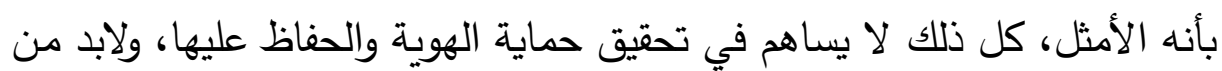

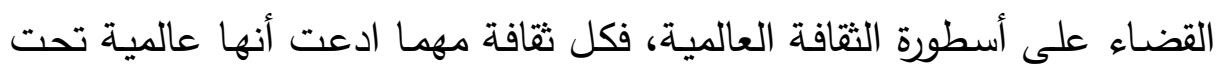

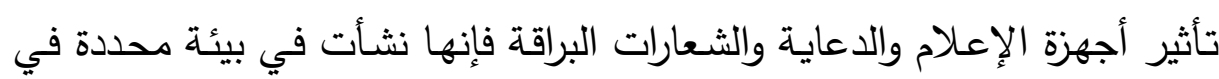

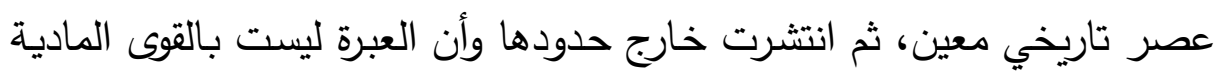

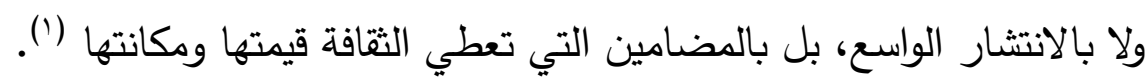
ت- - مخاطبة الناس على قدر عقولهم:

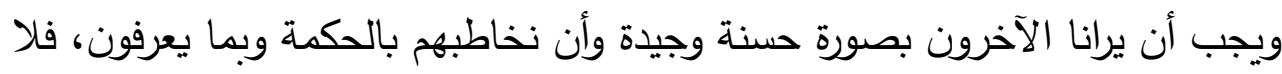

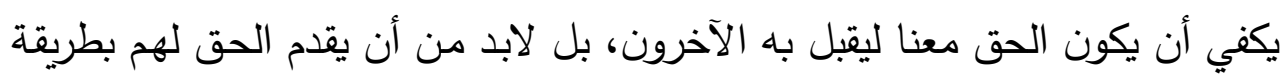

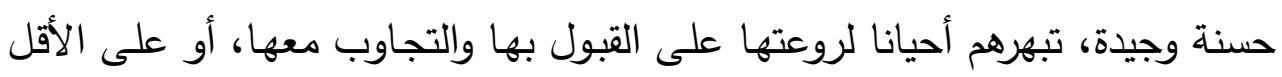

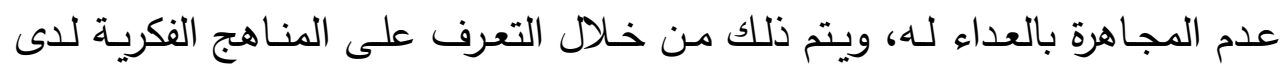

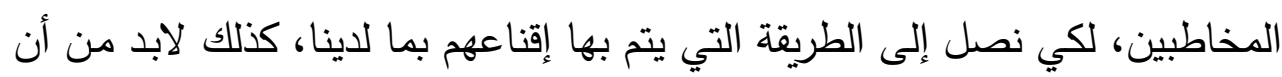

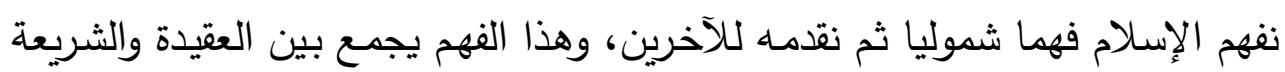

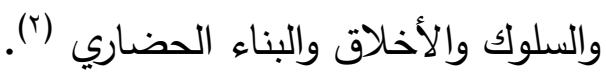

1 - الثقافة العربية بين العولمة والخصوصية : د . حسن حنفي ص ب ب ، بحث مقدم إلى المؤتمر العلمي الرابع لكلية الآداب والفنون ، بعنوان : العولمة والهوية مايو سنة 991 ام ، منشورات جامعة فيلادلفيا بألمانيا

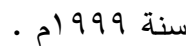

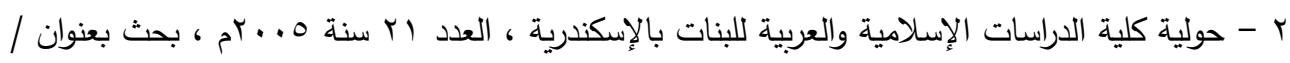

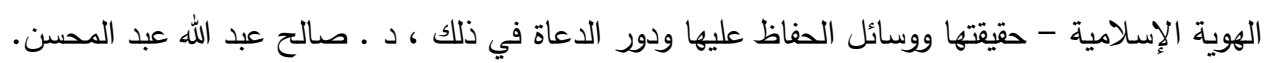


الهوية الإسلامية (روية تأصيلية في ضوء التحديات المعاصرة)

** قوة الهوية الإسلامية تحتاج إلى قوة الأمة وتميزها:

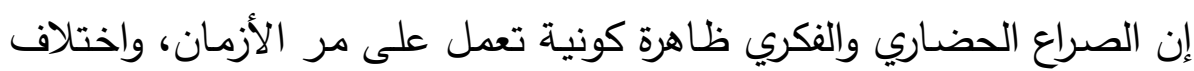
* Cor \&

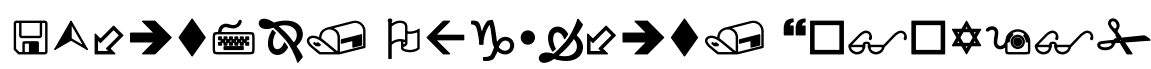

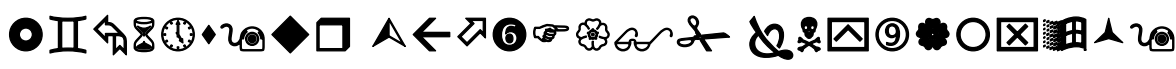

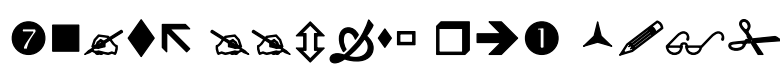

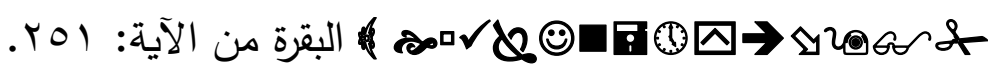

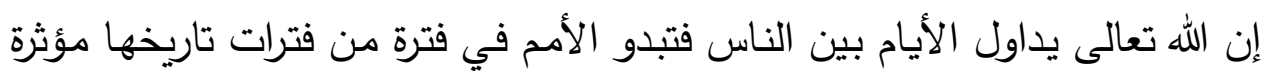

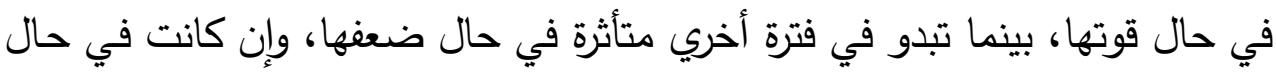

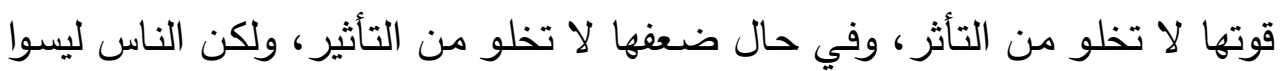

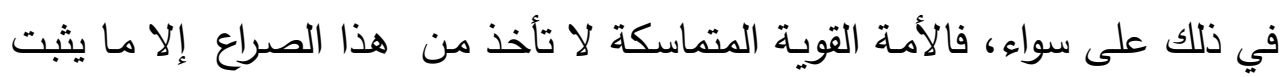

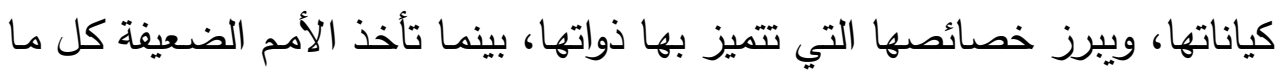

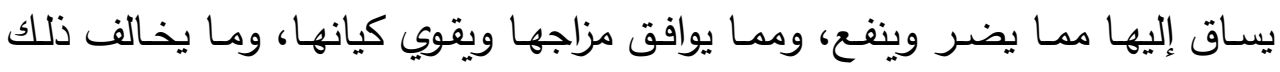

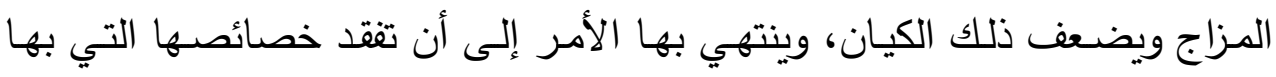

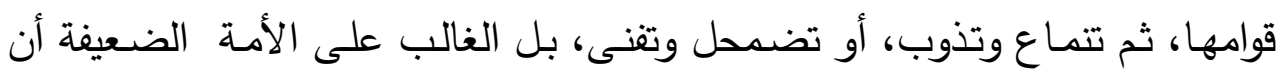

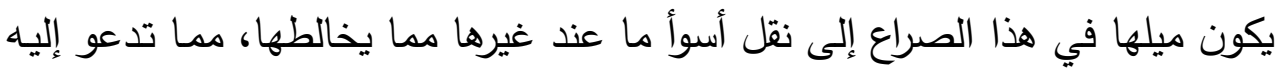

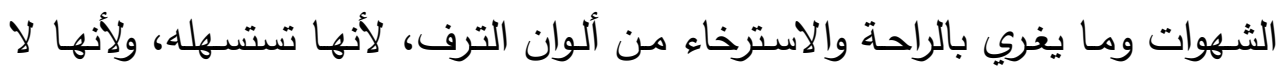

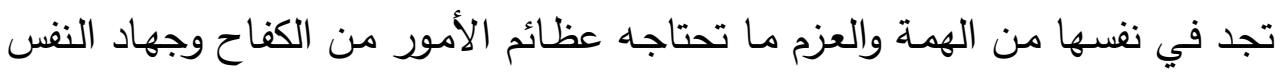
وحملها على ما تكره من الدأب والعمل والمغامرة.

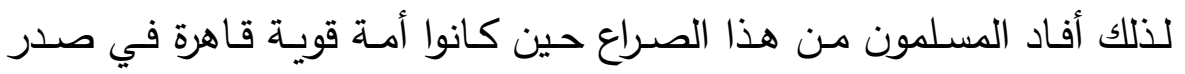

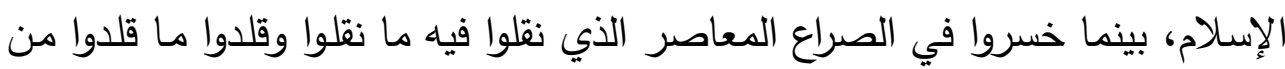

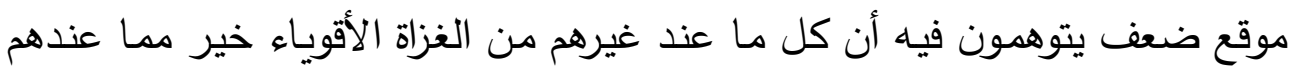


الهوية الإسلامية (روية تأصيلية في ضوء التحديات المعاصرة)

(1)

1 - الإسلام والحضارة الغربية : د ـ محمد محمد حسين ، طبع مؤسسة الرسالة بيروت سنة ولو 1.

$-199-$ 
الهوية الإسلامية (روية تأصيلية في ضوء التحديات المعاصرة)

\author{
الفصل الثالث \\ مسئولية الأمة في الحفاظ على الهوية الإسلامية الفهل

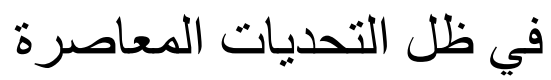 \\ ويشتمل على مبحثين: \\ المبحث الأول: دور المؤسسات الدعوية والاجتماعية في ترسيخ الهوية \\ في قلوب المسلمين. \\ المبحث الثاني: الهوية الإسلامية في ضوء التحليات المعاصرة.
}




\section{الهوية الإسلامية (روية تأصيلية في ضوء التحديات المعاصرة)}

الفصل الثالث

مسئولية الأمة في الحفاظ على الهوية الإسلامية

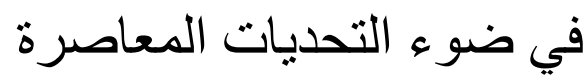

تبين لنا من خلال العرض السابق أن الهوية الإسلامية تواجه الكثير من التحديات في

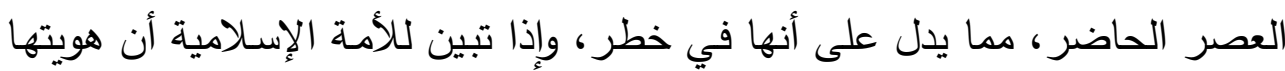

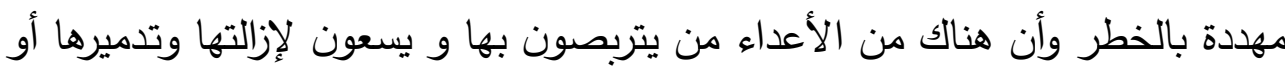

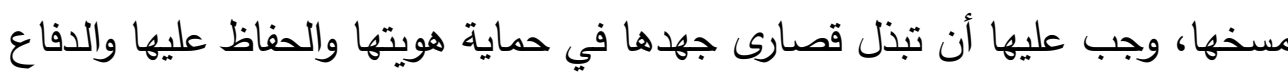
عنها بشتى الوسائل والأساليب، متحلية بالصبر والعزيمة،و إلا فسوف تكون النتيجة

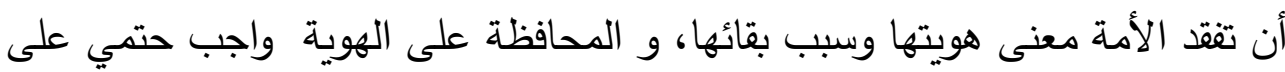

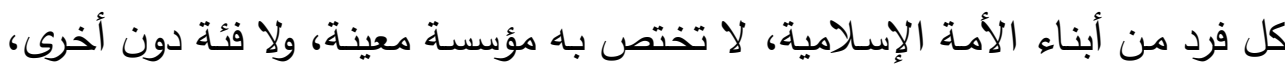

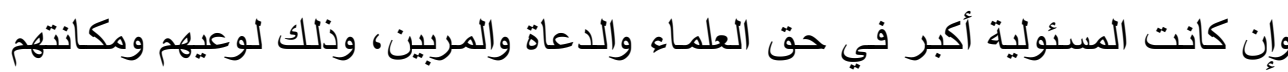
ومسئوليتهم أمام الله تعالى، ولأنهم أثد الناس معرفة لكائ لما يدبر للأمة الإسلامية. وسوف أتناول هذا من خلال مبحثين:

\section{المبحث الأول}

دور المؤسسات الدعوية والاجتماعية لترسيخ الهوية في قلوب الاوب

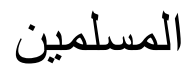

وأذكر هنا بعض المؤسسات التي يجب أن تتصدى للدفاع عن الهوية، وتوجيه

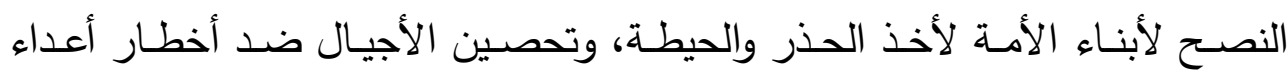
الإسلام، وذلك من خلال المؤسسات التالية:

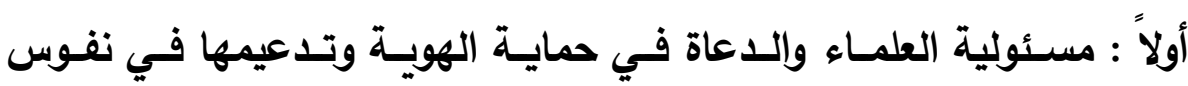

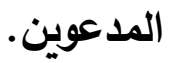
إن العلماء والدعاة والمفكرين المسلمين عليهم دور كبير ومسئولية عظمى ملقاة 


\section{الهوية الإسلامية (روية تأصيلية في ضوء التحديات المعاصرة)}

على عاتقهم في ظل الأخطار والتحديات التي تتعرض لها الهوية الإسلامية، من أجل

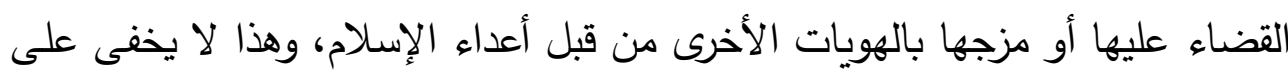

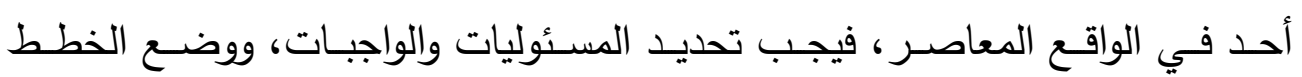
والمناهج، وإيجاد مناخ إسلامي يتوافق دع تعاليم الإسلام وقيمه الاجتماعية، ومن هنا

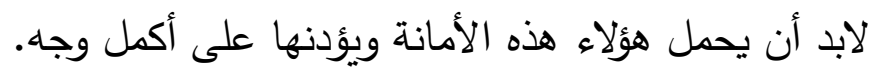

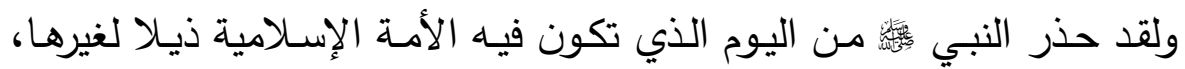

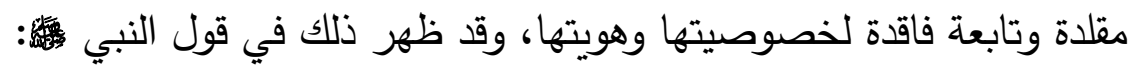

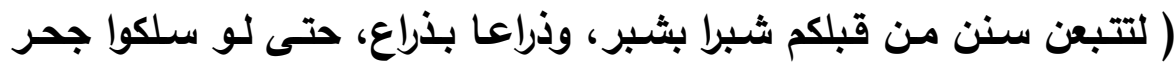

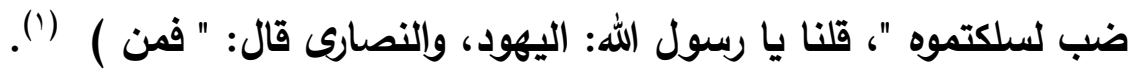

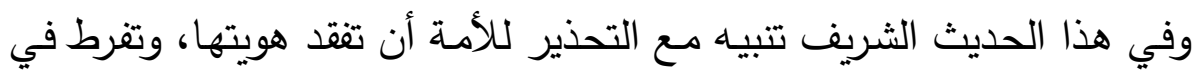

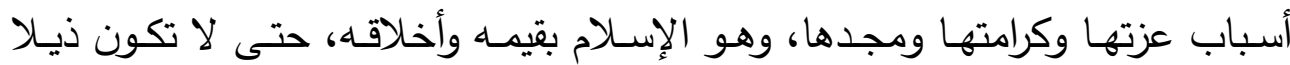

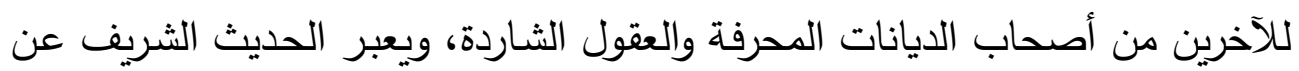

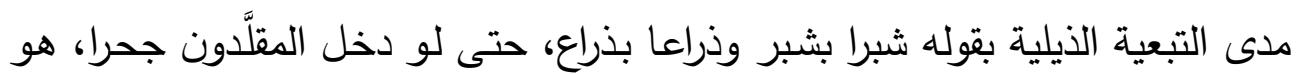

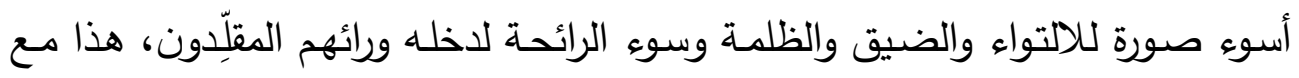
حرص الإسلام البالغ في تشريعاته وتوجيهاته على أن تظل الثخصية المسلمة مستقلة

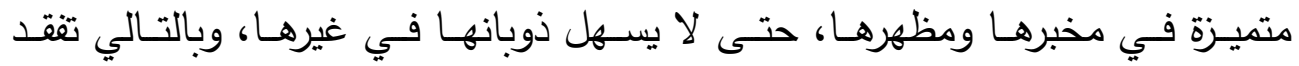
خصائصها وكيانها (r).

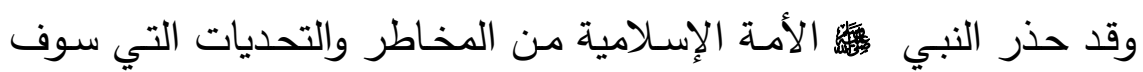
تتعرض لها مستقبلا، لتأخذ الحيطة والاستعداد في مواجهة هذه المخاطر ، فتكون

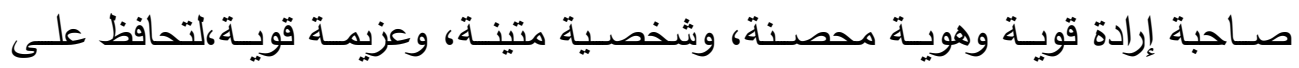

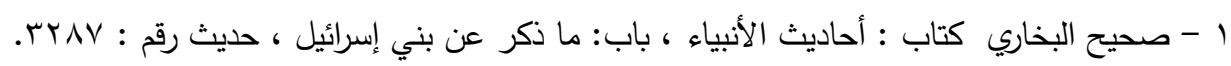

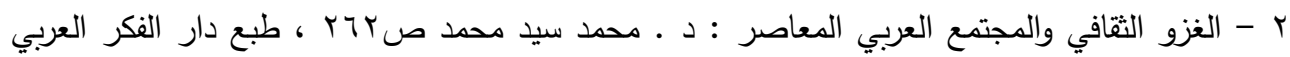

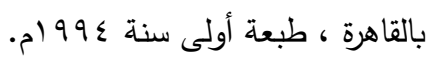


الهوية الإسلامية (روية تأصيلية في ضوء التحديات المعاصرة)

مقوماتها ومكانتها بين الأمم، لا أن يكونوا غثاء كغثاء السيل، لا قيمة لهم ولا كلمة،

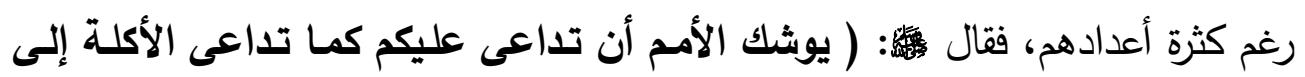

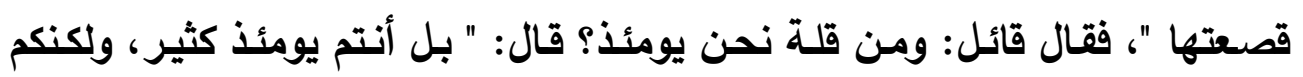
غثاء كفثاء السيل، ولينزعن الله من صدور عدوكم المهابة منكم، وليقذفن الله في

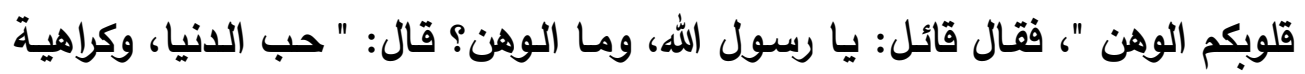

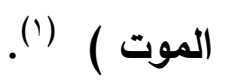
إن أعداء الإسـلام يتآمرون على الأمسة الإسـلامية ويخططون لمحوها، وكسر

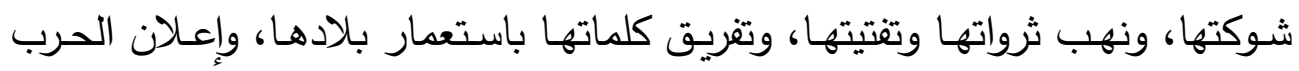

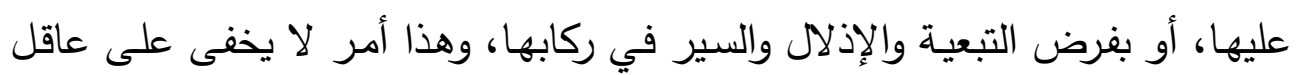

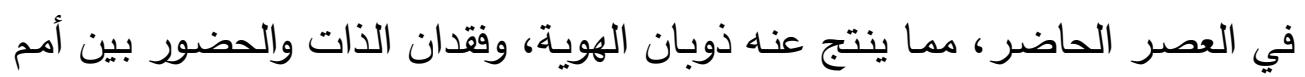

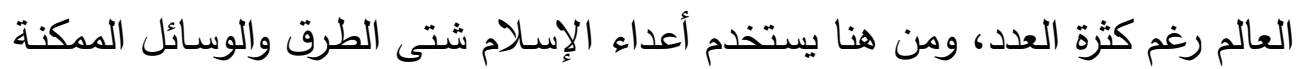
لتذويب هوية المسلمين وزلزلة أركانهم وزعزعة شخصياتهم واستقرارهم.

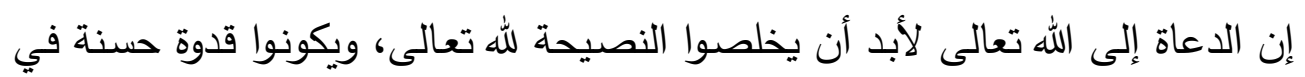

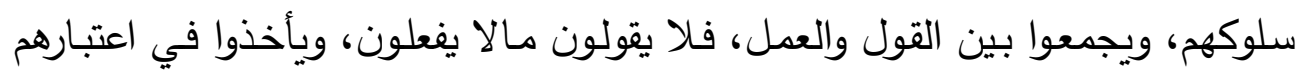

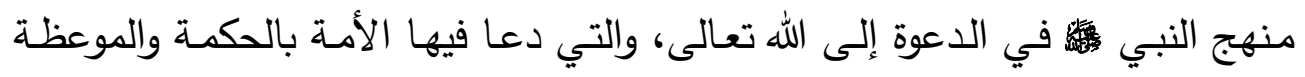

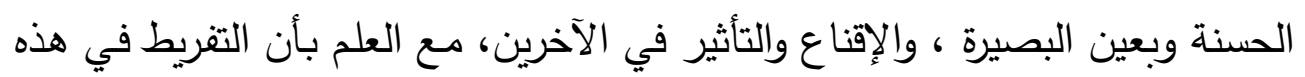

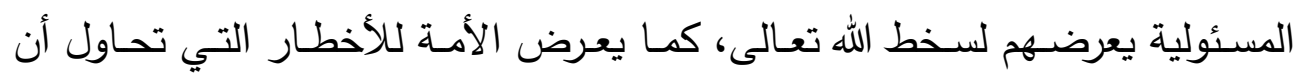

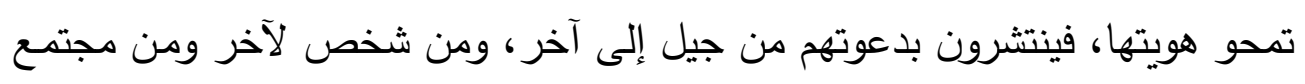

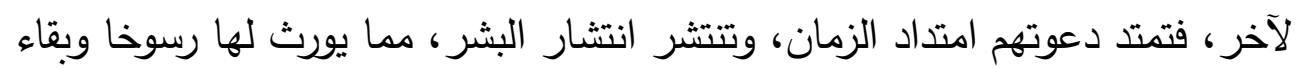

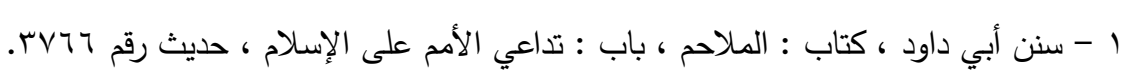

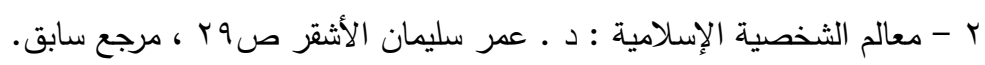

$$
\begin{aligned}
& -r \cdot r-
\end{aligned}
$$




\section{الهوية الإسلامية (روية تأصيلية في ضوء التحديات المعاصرة)}

وإذا كانت هذه المسئولية واجب وأمانة في حقهم، فهي أيضا واجب كل فرد من

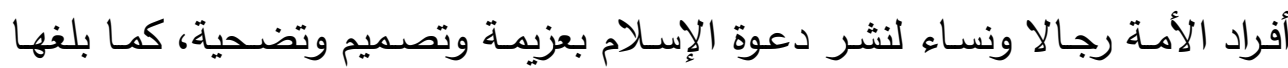
رسول الله

ثانياً : مسئولية الأسرة في تحصين الأبناء لصيانة الهوية:

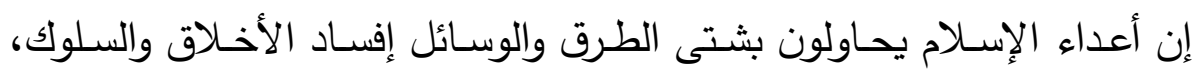

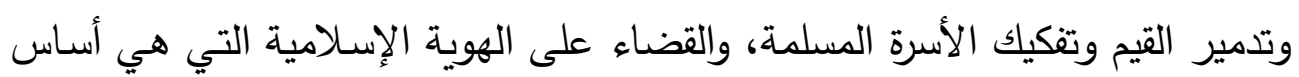

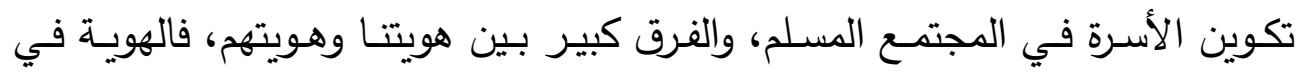

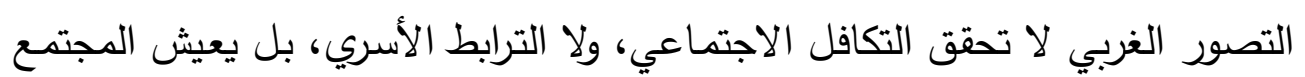
الغربي تشتت أسري ينتج عنه مشكلات اجتماعية عميقة.

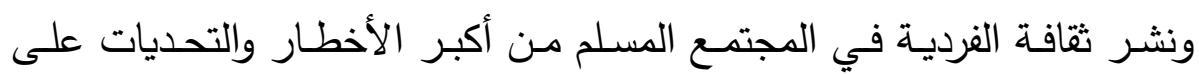

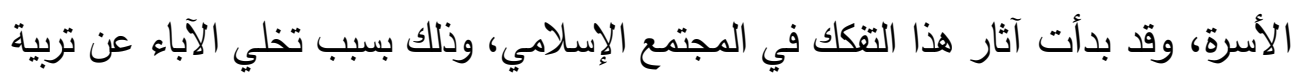
الأبناء، وحُسن توجيههم.

فلابد أن تتهض الأسرة بدورها الحقيقي في التربية، وغرس الهوية الإسلامية في

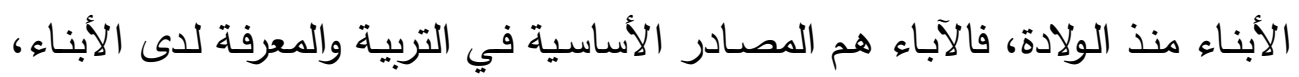

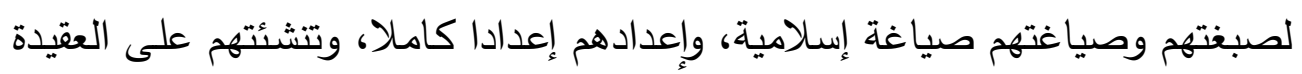

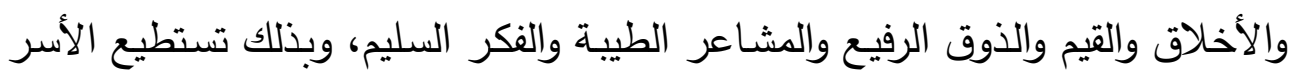
الإسلامية أن تكون أجيالا تشعر بصدق النتمائها للهوية الإسلامية واعتزازها بها.

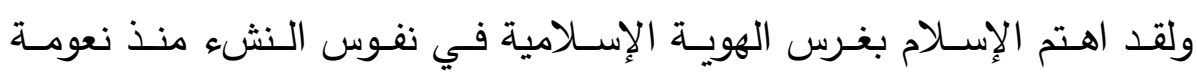
الأظفار ، وذلك بفرض التكاليف التشريعية في سن مبكرة منذ البلوغ، وأمر أولياء

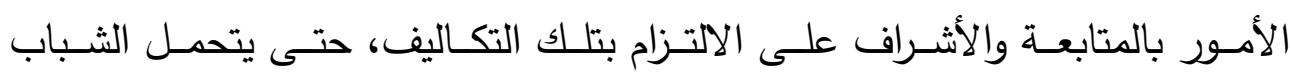

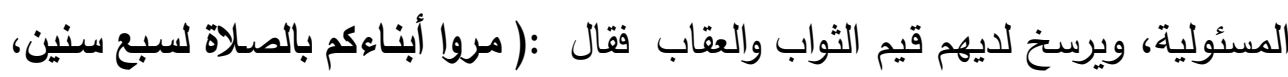


الهوية الإسلامية (روية تأصيلية في ضوء التحديات المعاصرة)

واضربوهم عليها لعشر سنين ) (').

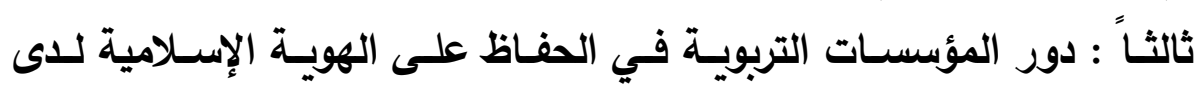

الأجيال المعاصرة:

وكذلك على المؤسسـات المعنيـة بالتربيـة والتعليم دور بارز في غرس الهويـة الإسـلامية في الأجيـال المسلمة،فمتى كان التعليم قويـا مرتبطـا بالهويـة، لـه أصسوله الراسخة وقواعده المتينة وشموله الواسع ومعايشته لشئون الحياة وارتباطه بواقع الناس، أثر ولا شك في حفاظ الناس على هويتهم وتمسكهم بدينهم، ولأجل ذلك كانت عناية

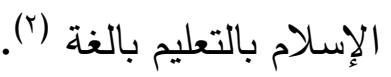

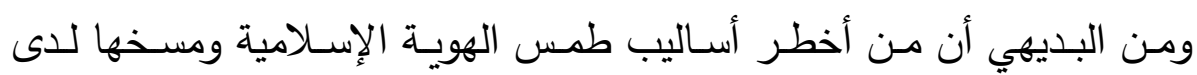
الأجيال، تسـميم الآبـار المعرفيـة التي تسـتقي منهـا الأجيـال، والمـراد تخريب منـاهج التعليم بكافة مراحله، وهذا يسمى تجفيف منابع الإسـلام، وبذلك يتم صياغة جيل لا علاقـة لـه بهويتـه الإســلامية إلا علاقـة اسـمية فقط، لقـد أصـبح التعليم في العـالم الإسلامي يجري على تخطيط غربي، رسمه الاستعمار وأشرف على تتفيذه بنفسه، أو بأيدي صـنائعها مـن الأصدقاء والعمـلاء، ولذلك كان جهدهم الكبير على المسلمين

خاصة لارتباط حياتهم في مختلف مناشطها بالدين (r). ويكفي دلالة على خطورة التعليم في التأثير على الهويـة، إن القس " دانلوب " تمكن في عشرين سنة من تخريب العقول والنفوس والضمائر والعواطف من خـلا سياسته التعليمية بصورة ما كانت بريطانيا تحلم بتحقيق ربعها لو جندت في سبيل ذلك

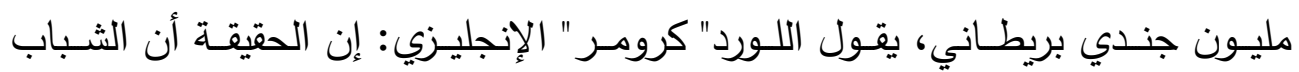

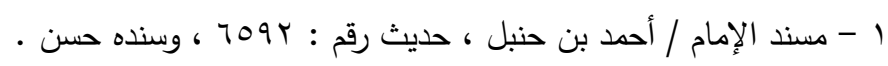

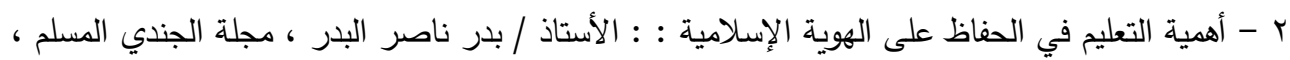

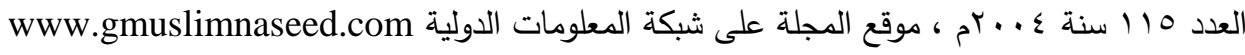

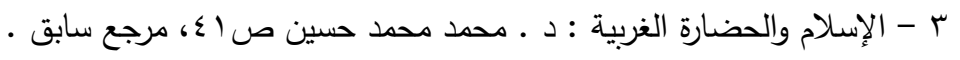




\section{الهوية الإسلامية (روية تأصيلية في ضوء التحديات المعاصرة)}

المصـري الذـي قد دخـل في طاحونـة التعليم الغربي، ومـر بعمليـة الطــن، يفقد

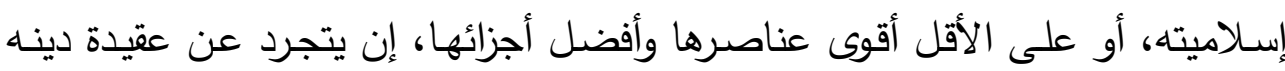

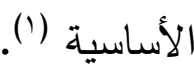

لقد أدرك أعداء الإسـلام مدى ضـرورة فتح المـدارس الأجنبيـة في البلاد الإسلامية، وذلك لعملية التطهير الديني، والتبشير بعقائدهم المناقضة لدين الإسـلام،

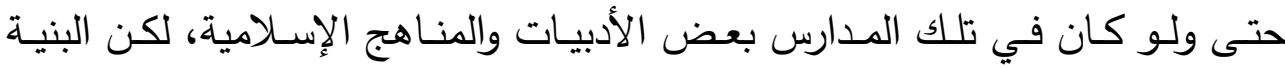

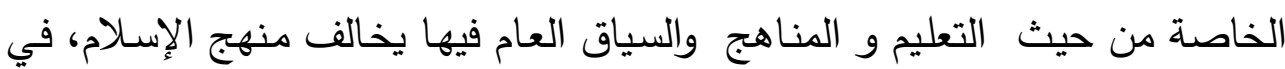
صناعة فرد مسلم متكامل النسيج الديني والأخلاقي. إن خريجي هذه المدارس سوف يكونون أتباع للغرب، ينادون بالهويـة الغربية،

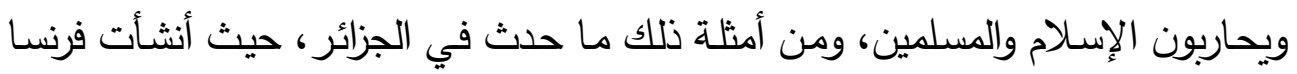
عددا من المدارس سميت زورا " المدارس العربية "، لكن تلك الخديعة الكبرى لم تتطل

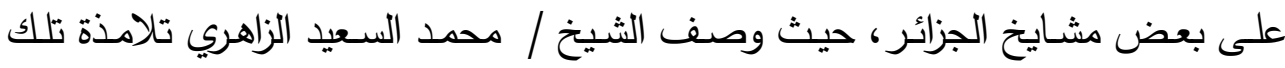

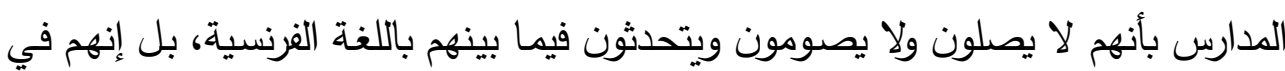

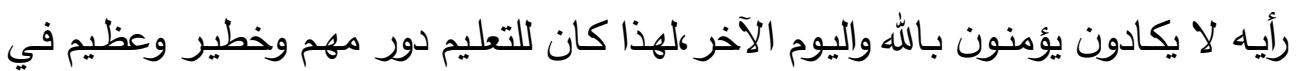

المحافظة على الهوية الإسلامية وصيانتها ورعايتها (؟). فيجب على المسئولين عن التربية والتعليم، تحمل المسئولية كاملة، في تأدية

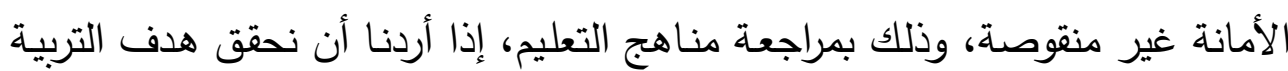

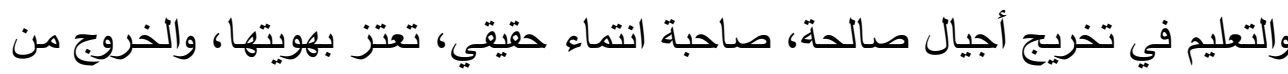

1 - ندوة منشورة في مجلة البيان اللندنية : د ـ محمد إسماعيل المقدم ، في موقع المجلة على الثبكة

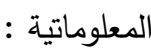
www.albayan-magazine.com/dialogyes/101/ht r - هل الهوية في خطر : الأستاذ / خباب مروان الحمد ، بحث منشور في موقع الإنسلام اليوم على الشبكة المعلوماتية : Htt://www.islamtoday.net/files/wedib9.htm 


\section{الهوية الإسلامية (روية تأصيلية في ضوء التحديات المعاصرة)}

التبعيـة الغربيـة في منـاهج التعليم، والتتي وضـع أسسـها المستعمرين أعداء الإسـلام، وبذلك تخرج إلى النور الأجيال المحبة لأمتها ووطنها.

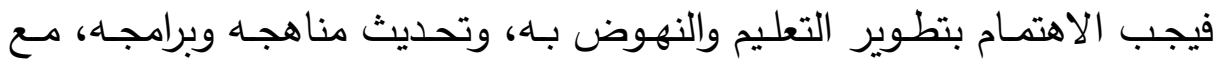
التركيز على التعليم النافع، الذي يفيد الفرد والدجمع، والذي يربي الأجيال على ثقافة

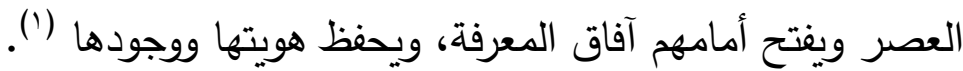

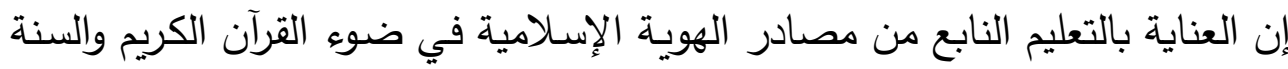
المطهرة، والاهتمام بالتعليم الأزهري، والمعاهد الدينية، التي ترسخ لاى المسلم انتماؤه

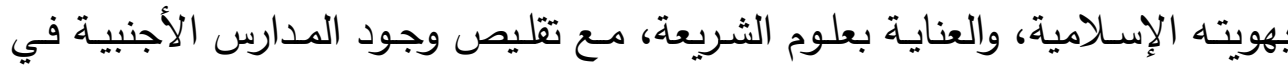

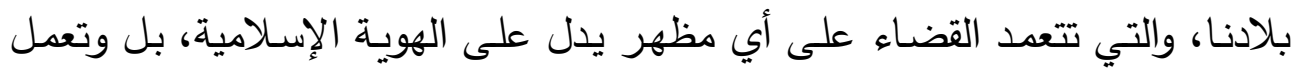

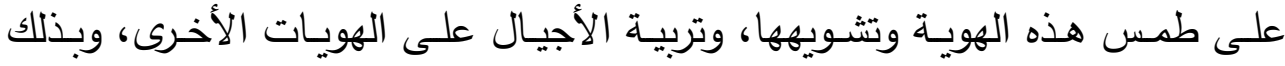

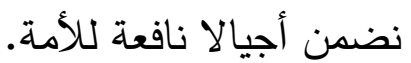

رابعاً : مسئولية الحكام والولاة في الحفاظ على الهوية الإسلامية للأمة:

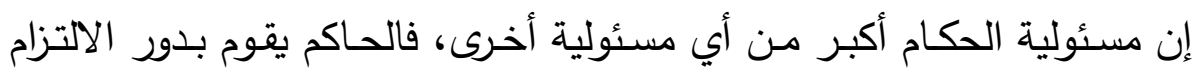

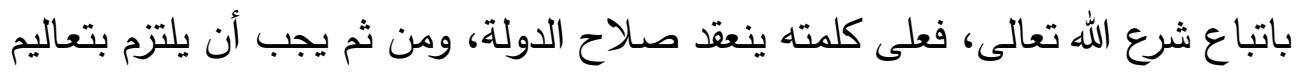

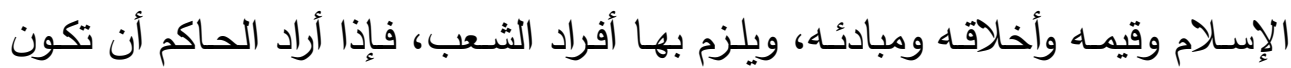

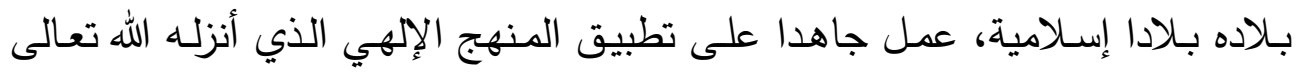
لعباده، فعندها تبلغ الأمة الإسلامية قمة المجد والعظمة والقوة.

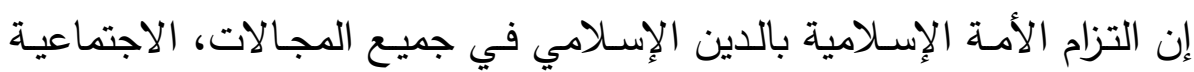

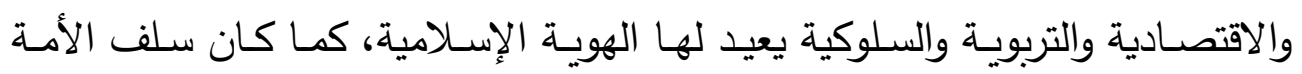
الصالح، وكما أرادها الله تعالى لها، لا كما يريدها أعداء الإسلام (r).

1 - العالم الإسلامي في عصر العولمة : د ـ عبد العزيز عثمان التويجري ص . ب مرجع سابق. r - حوار مع د ـ عفاف مختار حول الهوية الإسلامية ،منشور على شبكة المعلومات الدولية . 


\section{الهوية الإسلامية (روية تأصيلية في ضوء التحديات المعاصرة)}

\section{خامساً : دور وسائل الإعلام في نشر الوعي والحفاظ على الهوية:}

إن من أعظم وأخطر الوسائل التي استخدمها الغرب لطمس الهوية الإسلامية،

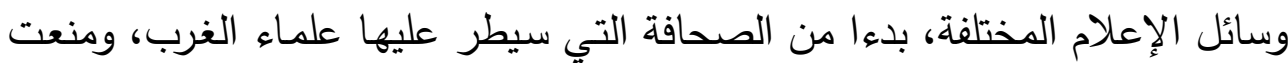

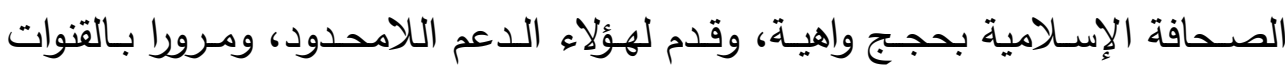

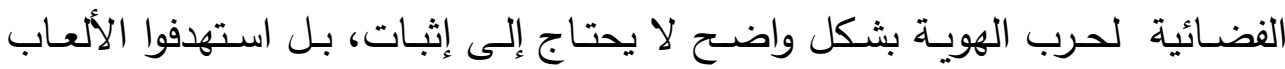

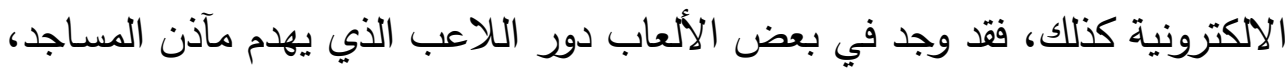
ويتقدم أكثر كلما هدم أكثر، فأي حرب للهوية أكثر من أن يغرس في في الطفل هدم

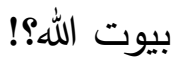

وعلى نفس المنهج تم إنتاج وترجمة المسرحيات والأفلام التي تدمر الأخلاق، وتخل بالعقيدة، وتلقي في نفوس النشء الثبهات حول الإسـام، ومفاهيمه وأحكامـه

$$
\text { وأصوله وتاريخه (') }
$$

إن أعداء الإسـلام قاموا بتوظيف المؤسسـات الصحفية والإعلاميـة في خدمـة الصاء

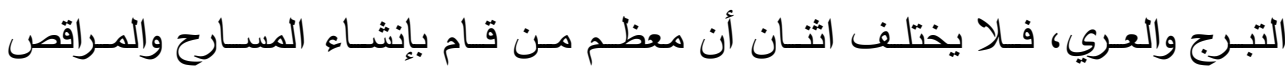
والخمارات في البلدان الإسلامية هم اليهود والنصارى، ثم قاموا ببث سمومهم وشبهاتهم حول قضايا الإسلام بهدف التشكيك في الهوية الإسلامية، وإبعاد المسلمين عن دينهم.

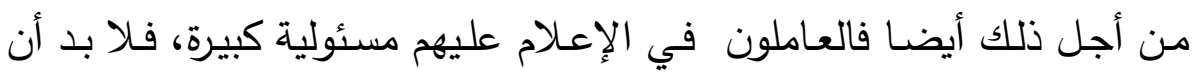
يوجهوا الناس توجيها إسلاميا يتفق مع تعاليم الدين الإسلامي، وقيمه الرفيعة، ويأخذوا

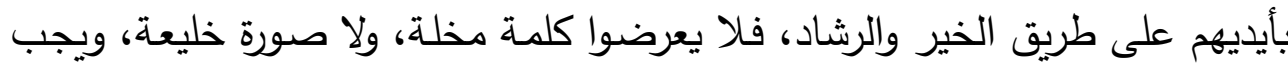
عليهم أن يبعدوا الناس عن الرذائل، وعلى عاتق الإعلام والمسئولين عنه مسئولية توضيح تعاليم الإسلام في صورة سهلة ميسرة مقنعة (†).

1 - حراسة الهوية أم التغريب لمن ؟ بحث منشور على شبكة المعلومات الدولية www.shobohat.com/vp/showthread.pht?t=11028 Y - حوار مع د ـ عفاف مختار حول الهوية الإسلامية ، منشور على شبكة المعلومات الدولية . 
الهوية الإسلامية (روية تأصيلية في ضوء التحديات المعاصرة)

• دور وسائل الإعلام في مواجهة أخطار العولمة:

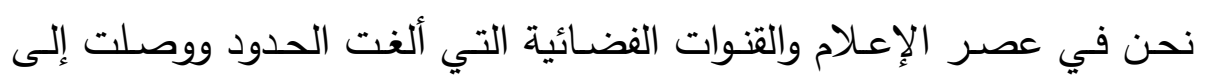

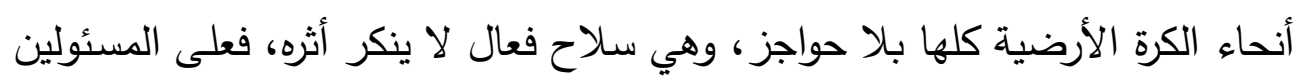

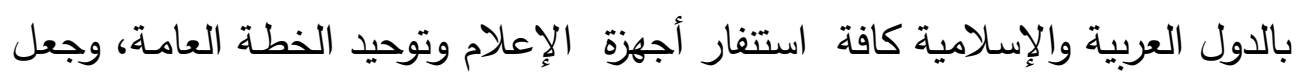

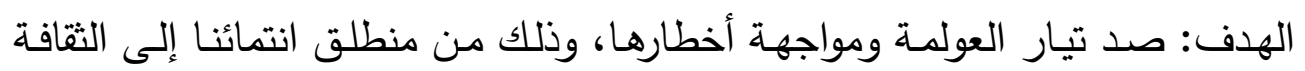

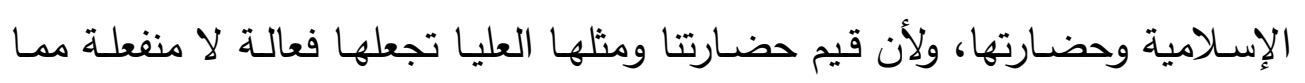
يستوجب عناية الإعلام بالتركيز على نقاط التمايز من حيث تصورنا للحياة......وهكذا

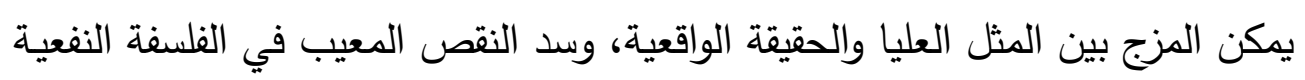
التي تتبناها العولمة (').

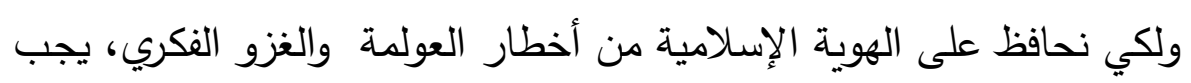

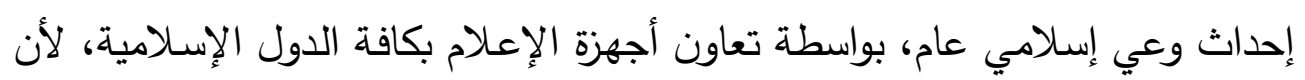

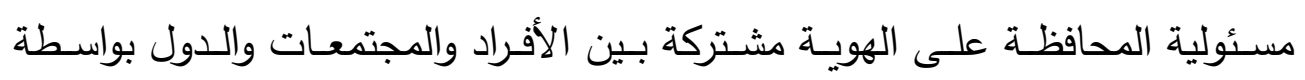
طريقين:

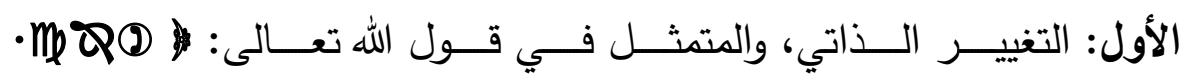

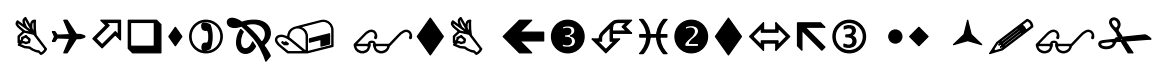

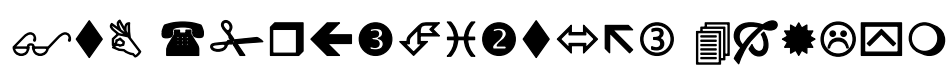

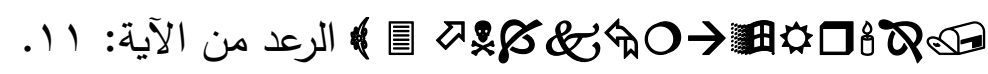

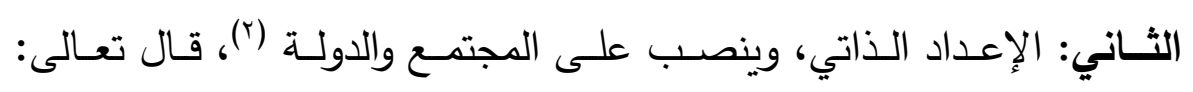

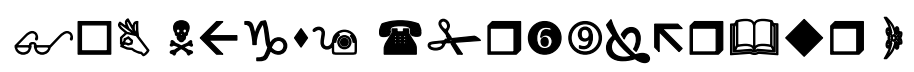

1 - الإسلام في عصر العولمة ، كتاب المؤتمر الدولي الرابع للفلسفة الإسلامية ص. بآ ، بحث بعنوان :

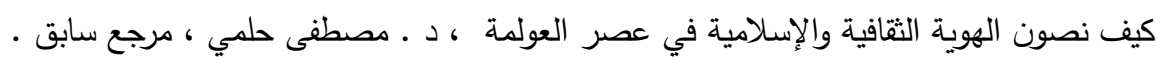

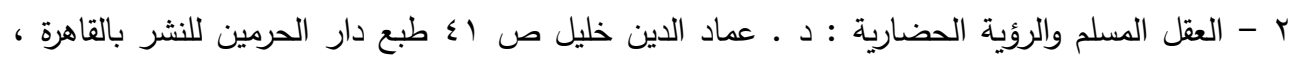

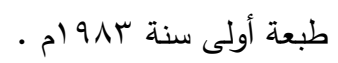


الهوية الإسلامية (روئة تأصيلية في ضوء التحديات المعاصرة)

केख

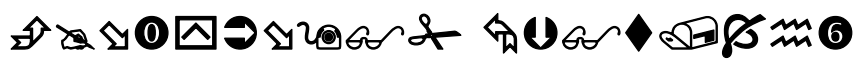

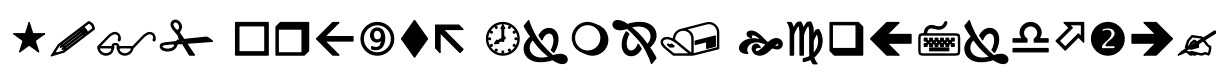
T. الأنفال

وذلك لأن الإسـام قول وعمل، ولذلك تمتد شعب الإيمان في شرايين المسلم،

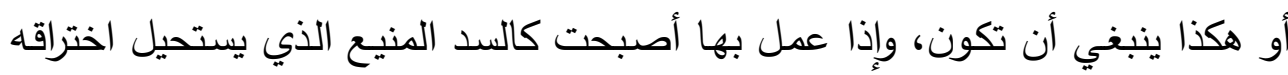

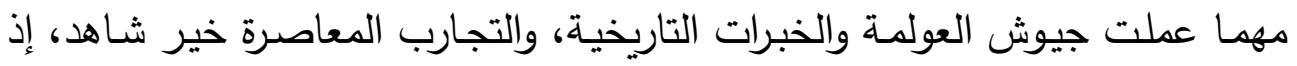
بعد انغراط عقد وحدة الأمة وهي الخلافة الإسلامية، لجاء المسلمون بفطرتهم بغريزة

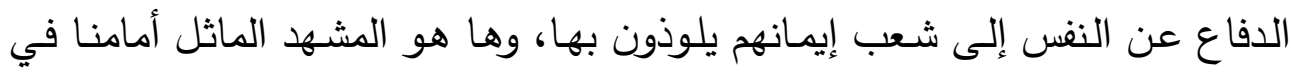
التضحيات المتواصلة للأقليات الإسلامية في العالم أمام محاولات الاستئصال ('). المبحث الثاني

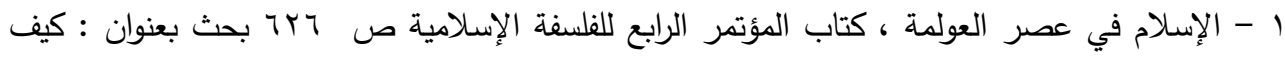

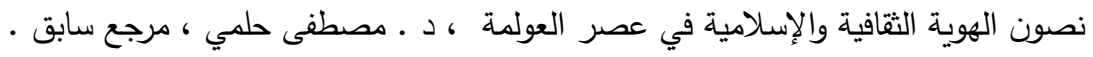
$-r_{1} \cdot-$ 
الهوية الإسلامية (روية تأصيلية في ضوء التحديات المعاصرة)

الهوية الإسلامية في ضوء التحديات المعاصرة

لقد حرص الإسلام على حفظ الهوية الإسلامية، وتحصين المسلمين ضد الأفكار

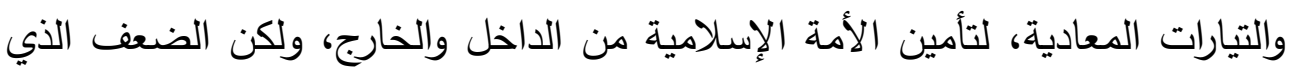

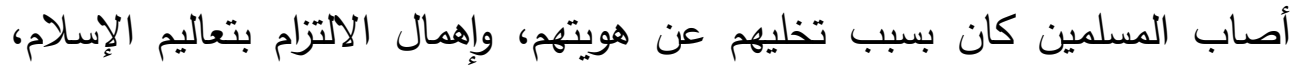

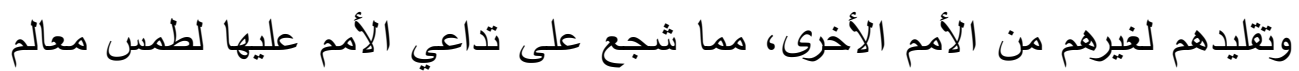
وجودها، وتحدي الأمم الأخرى لهوية الأمة الإسلامية لذوبانها وفرض الألئ السيطرة عليها، 囚曾

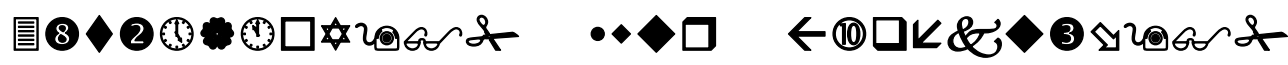

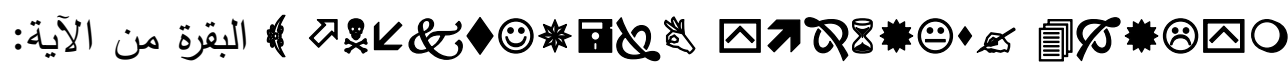

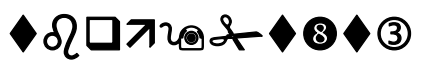
濖

$.1 \%$.

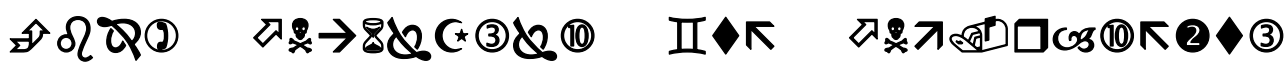

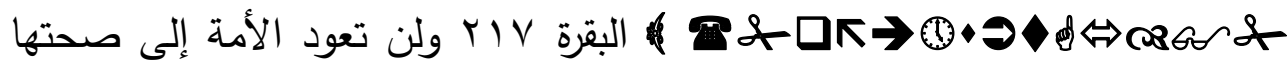
وعافيتها، واستعادة مجدها، إلا إذا حافظت على هويتها الإسلامية، وحصنت أجيالها ضد الغزو الفكري والثقافي ومارد العولمة، الذي تتخذه دول الغرب ستارا خادعا براقا لنشر فسادها في دول العالم خاصة الدول الإسلامية، التي تواجه العديد من التحديات في العصر الحاضر. وسوف يتضح ذلك من خلال النقاط التالية: الهوية بين تهاون العالم الإسلامي وحفاظ الغرب:

لقد ضربت الدول الغربية في العصر الحديث أعظم الأمثلة في المحافظة على هويتها

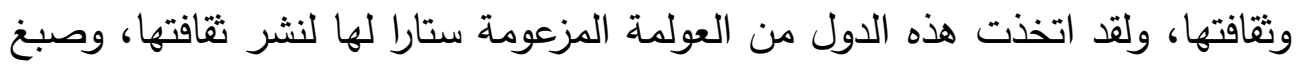
دول العالم بصبغتها، وفي مقابل ذلك حرصت على ألا تعطي فرصة للهويات الأخرى 


\section{الهوية الإسلامية (روية تأصيلية في ضوء التحديات المعاصرة)}

$$
\text { أن تتحرك أو تثبت وجودها. }
$$

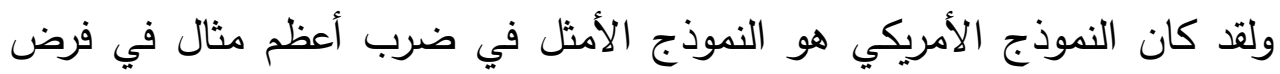

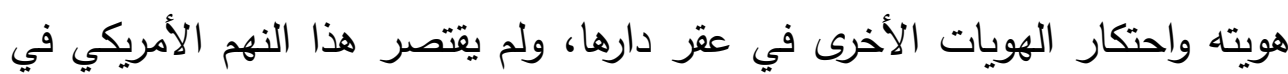

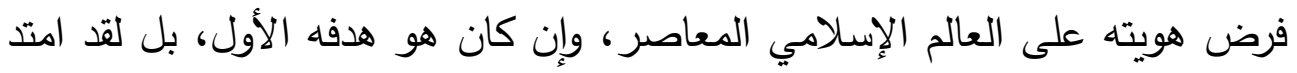

$$
\text { وشمل دولا غربية ونصرانية. }
$$

وإذا كان هذا الحرص على الهوية بين الدول الغربية من بعضها على ما بينها من ونائ تقارب واتفاق، فما بالنا بمدى خوفهر جميعا على هويتهم من الهوية الإسلامية

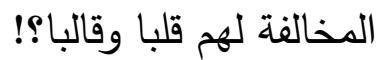
إن خوف الغرب من الهوية الإسلامية ليس جديدا، وإنما هو أمر قديم، وكانت الهوية

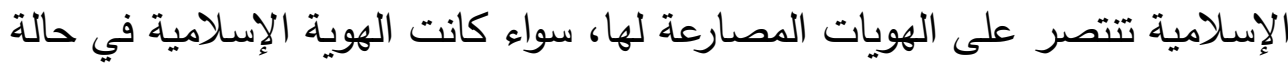
قوة أم في حالة ضعف، ولعل هذا السبب هو الذي جعل قادة الغرب المعاصرين السياسيين، والفكريين المثقين - يخافون من الإسلام أثد الخوف لتأثير الهوية

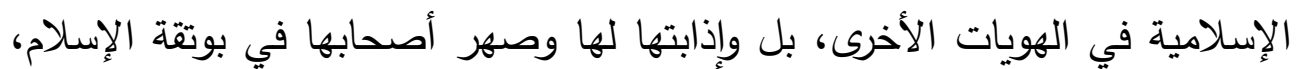
في حالة انتصار الإسلام وقوته.

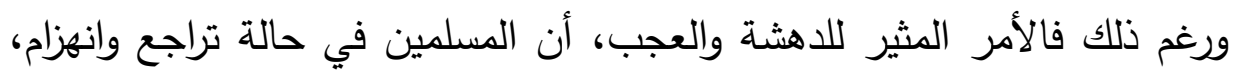
وتفريط للهوية الإسلامية، وتقليد للهويات الأخرى بغير علم ولا هدى، إلا تقليد

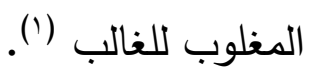
ومما يؤسف له أن بعض المثققين في العالم العربي والإسلامي، يطرح قضية الهوية الإسلامية طرحا مختزلا، ينفي عن الأمة أهم صفة من صفاتها، بل حقيقة وجودها،

1 - الهوية الإنسلامية والمؤامرة عليها : د . ناصر دسوقي رمضان ، مقال منشور بشبكة المعلومات الدولية www.alukah.net/sharia/0/8744

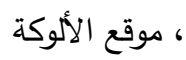




\section{الهوية الإسلامية (روية تأصيلية في ضوء التحديات المعاصرة)}

من خلال رفضه لهويتها، إلا أننا نرده إلى الظروف التي قد تكون فرضت تلك الرؤية،

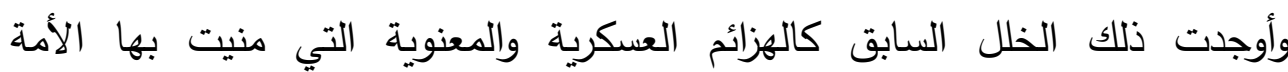
الإسلامية، إضافة إلى التخلف المادي التقني في مواجهة الطفرة العلمية، والاكتشافات

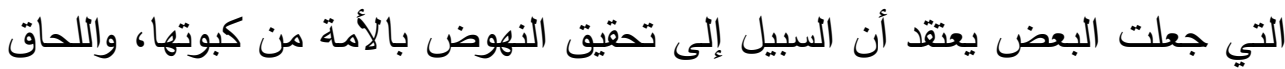

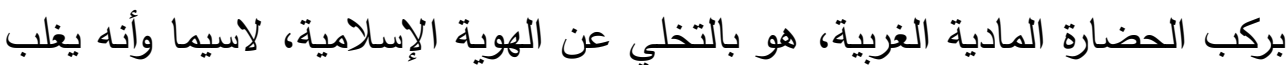

عليها الفكر الديني، لأنها كما زعموا تتعارض مع عقلية عصر العلم الحديث (1).

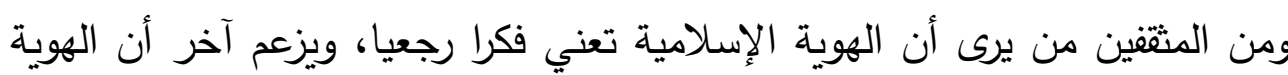

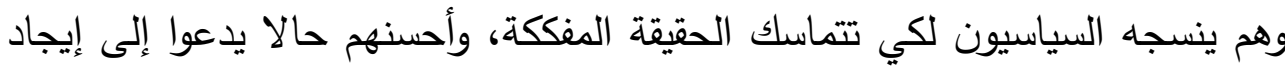

بديل للهوية يمثل هجنة ثقافية أو فكرية (r). ومنهم المتتاقض في طرحه الذي يرى أن الهوية غير ثابتة، بل يجب أن أن تتغير إذا إذاه

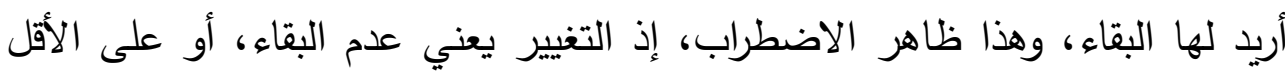

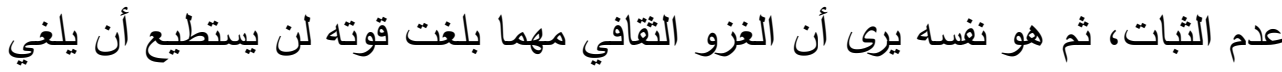

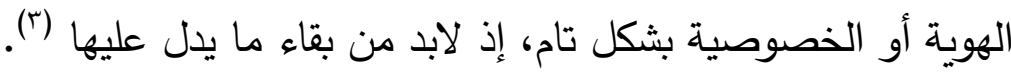
وكل هؤلاء يخالفون حقيقة الهوية الإسلامية، ويخلطون بين الأصل النقي الثابت الذي لأني لأناه يسعد البشرية، ويحقق لها التوازن، وبين ما هو دخيل مدسوس من الهويات الأخرى،

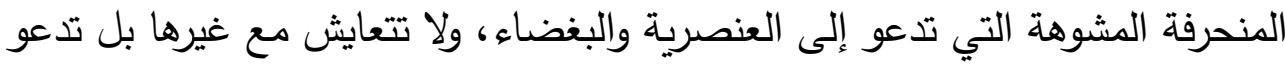

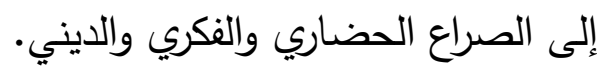

1 - الثخصية الإسلامية دراسة قرآنية : د ـ عائشة عبد الرحمن (بنت الثاطئ ) صلا ال ، طبع دار العلم

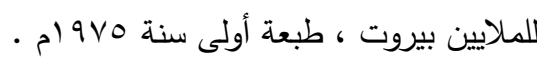
r - الهوية بين الجوهري والمضاف : الأستاذ / علي عقلة عرسان ، بحث مصند مصور في صحيفة الوطن

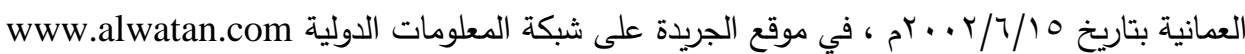

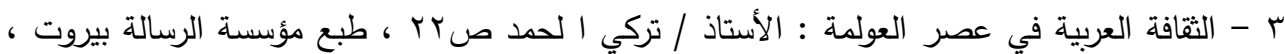

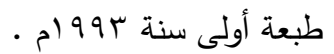




\section{الهوية الإسلامية (روية تأصيلية في ضوء التحديات المعاصرة)}

وفي المقابل نضرب بعض النماذج التي توضح مدى اعتزاز الغرب بهويته، وحفاظه

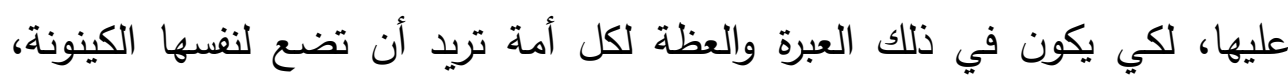
والخصوصية التي تميزها، وتضمن استقرارها وثبات وجودها بين أمم العالم.

\section{1- -}

نحن نعلم ما وصلت إليه اليابان من قوة تقنية وصناعية لا ينكرها منكر ، ونتذكر جيدا

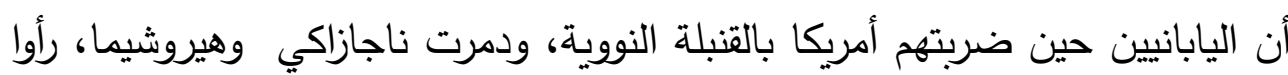

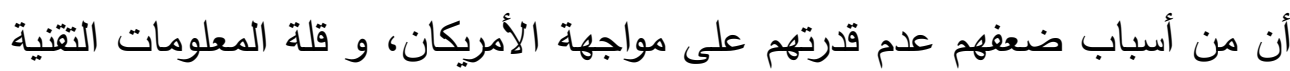

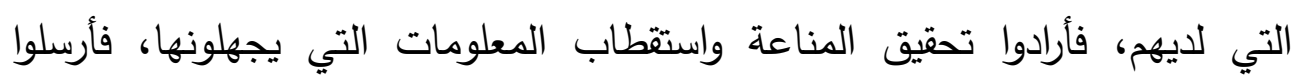
البعثات للتعليم في بلاد الغرب، والنهل من علومهم الطبيعية، حتى يرجعوا إلى اليابان

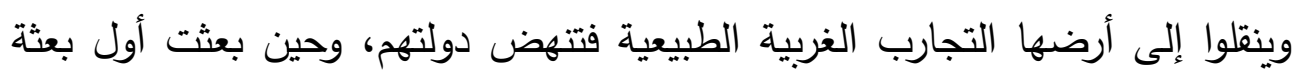

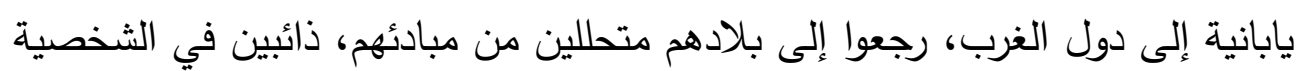

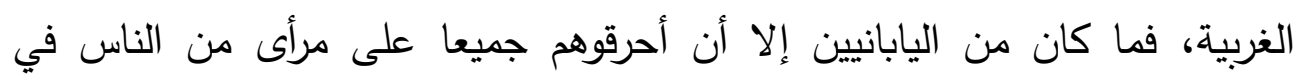

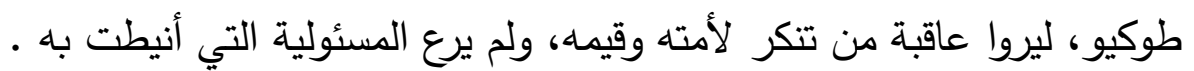

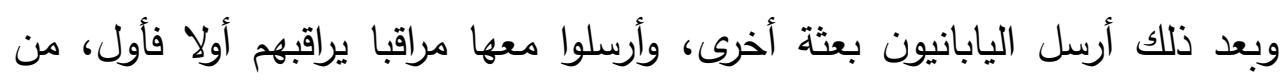

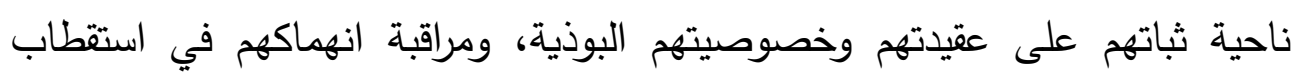

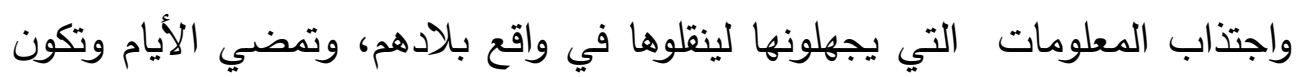

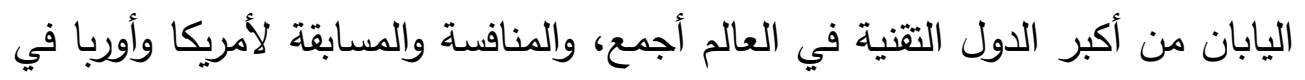
كثير من التخصصات التقنية (')

أليس في هذه القصة درس وعبرة، بما يفعله الآخرون من غير المسلمين في الحفاظ

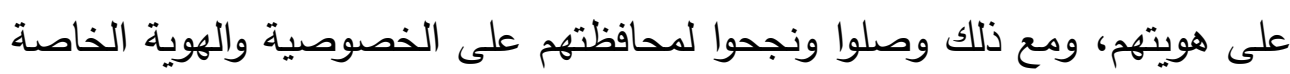

1 - هل الهوية في خطر ؟ الأستاذ : خباب بن مروان الحمد ، مقال منشور على موقع الإسلام اليوم على شبكة المعلومات الدولية: www.islamtoday.net 
الهوية الإسلامية (روية تأصيلية في ضوء التحديات المعاصرة)

بكه، فأولى بالأمة الإسلامية صاحبة الدين الحق المشهود لها بالخيرية والوسطية، بأن

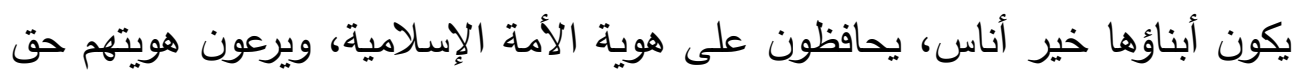

رعايتها.

r - اليهود يحافظون على هويتهم:

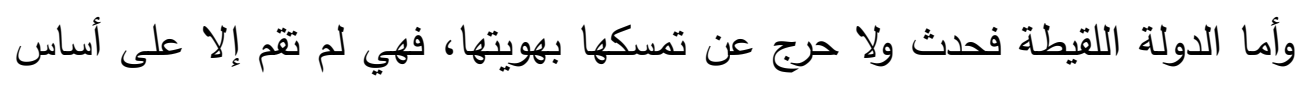

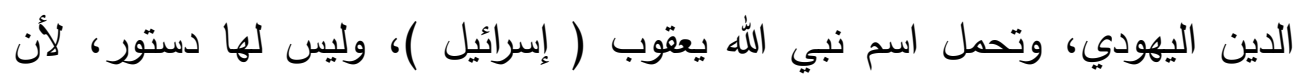

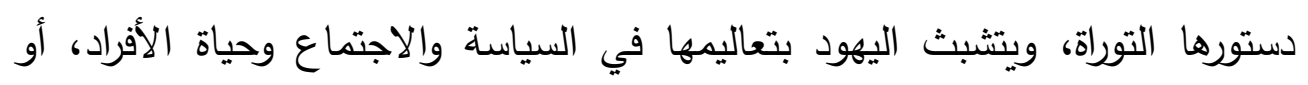

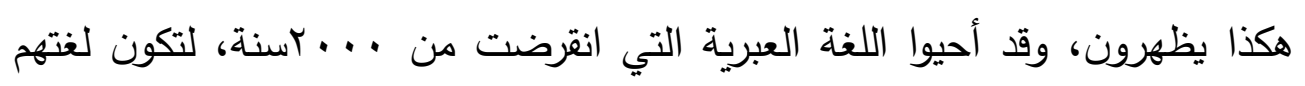

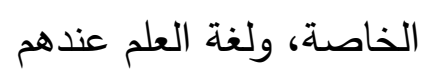
يقول "أدولف كريمر " اليهودي: جنسيتنا هي دين آبائنا، ونحن لا نعترف بأي قومية

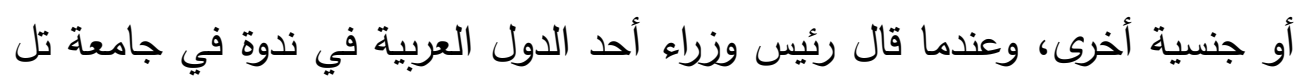

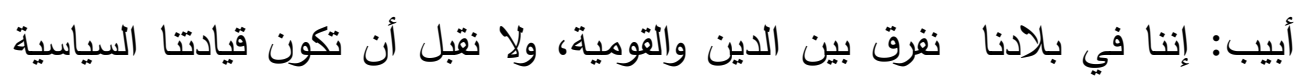

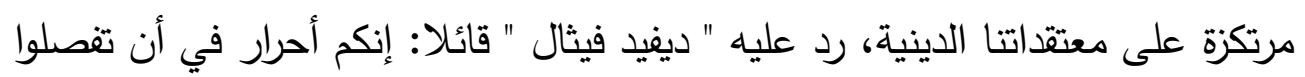

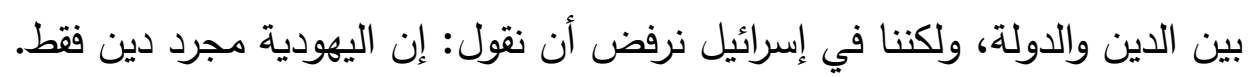

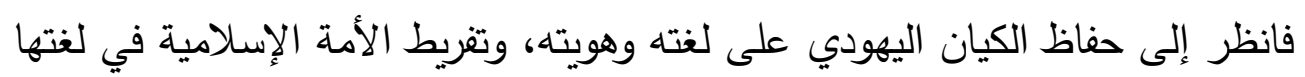
وهويتها.

\section{ب- الهند تحافظ على هويتها:}

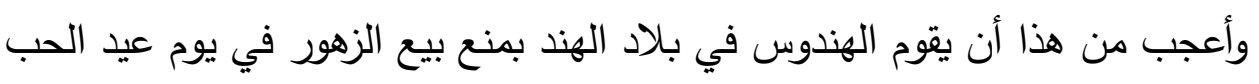

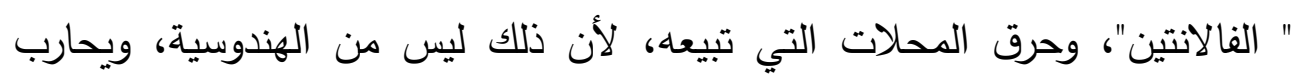

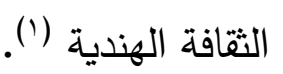

ولعل السبب في تقدم هذه الدول وحفظها على مكانتها بين أمم العالم هو، تمسكها

1 - صراع الهويات وخصائص الهوية الإسلامية ، مقال على شبكة المعلومات الدولية :www.islamweb.net/media/index.php?bage=article\&lang=a\&id=63232 
الهوية الإسلامية (روية تأصيلية في ضوء التحديات المعاصرة)

بهويتها، ودفاعها عنها، وتحصين شعوبها ضد الأخطار التي تحاول اختراق معتقداتها

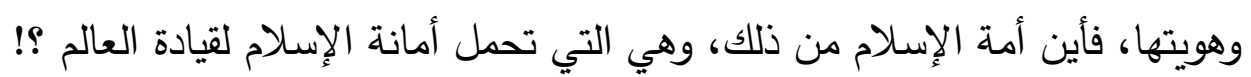
أساليب طمس الهوية الإسلامية:

لقد سلك أعداء الأمة من الداخل والخارج طرقا وأساليب ووسائل متعددة لطمس الهوية الإسلية الإسلامية، وتثويهها وإذابتها في غيرها من الهويات الأخرى.

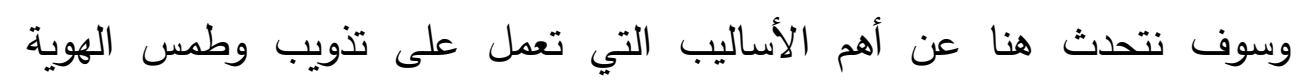
الإسلامية، وذلك في النقاط التالية:

التثكيك في العقيدة وإضعاف الاعتزاز بها.

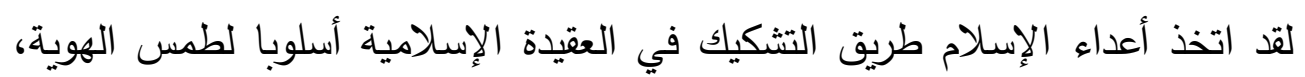

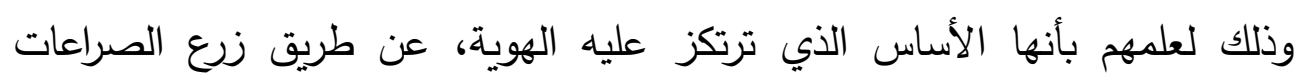

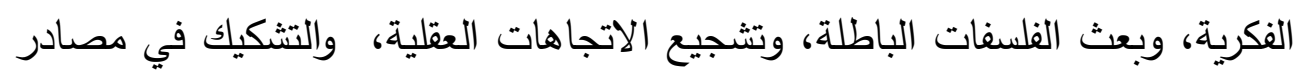

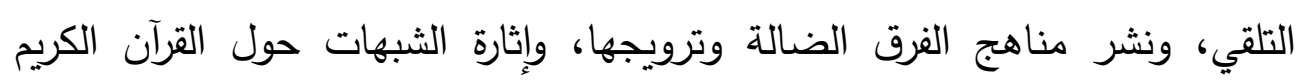

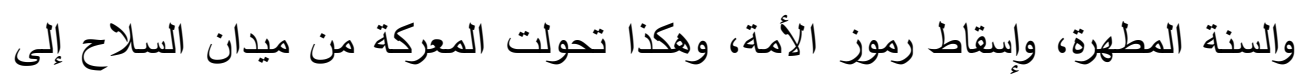

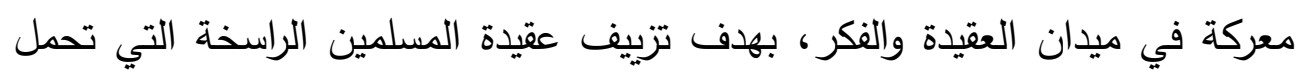
طابع الجهاد، وتدفع المؤمنين إلى الاستشهاد (').

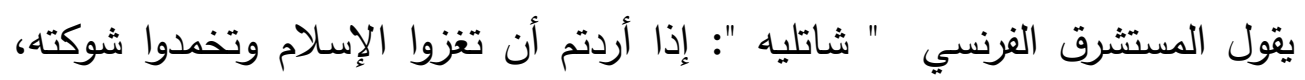

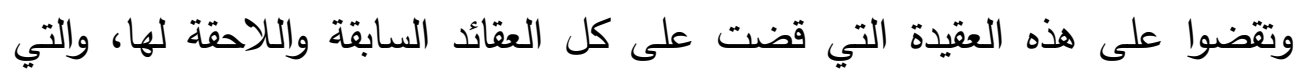
كانت السبب الأول والرئيس لاعتزاز المسلمين وشموخهم، وسبب سيادتهم وغزوهم

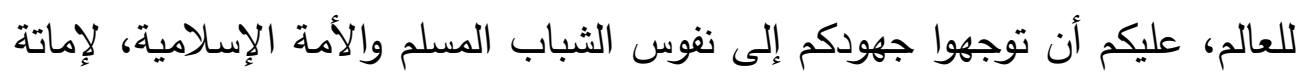

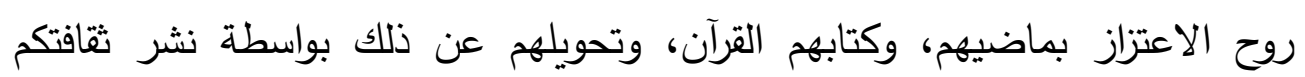

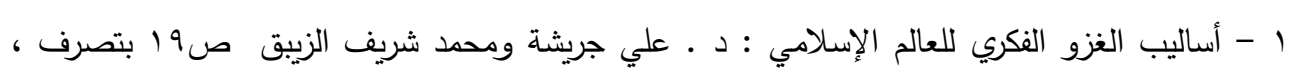

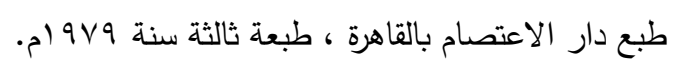




\section{الهوية الإسلامية (روية تأصيلية في ضوء التحديات المعاصرة)}

وتاريخكم، ونشر روح الإباحية، وتوفير عوامل الهدم المعنوي، حتى لو لم نجد سوى

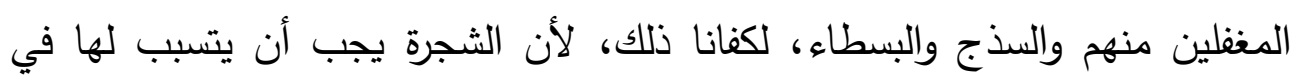

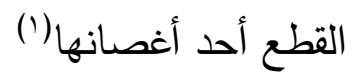
إن العقيدة الإسلامية تمثل عصب الهوية الإسلامية، فلا غنى عنها للفرد والهجتمع،

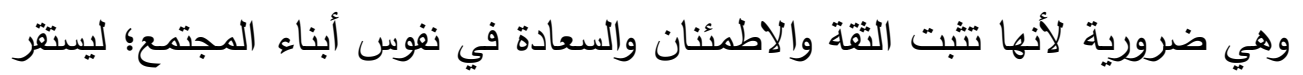

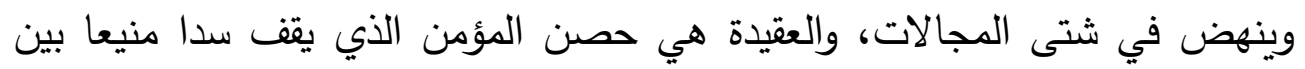

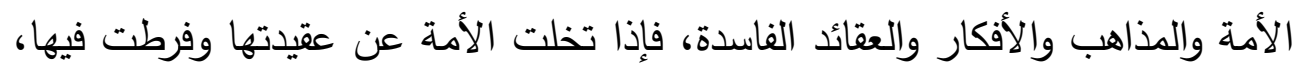
وتركت تعاليمها وأهملت أخلاقها، أصبحت ضعيفة فريسة جاهزة لكل من يقتحم

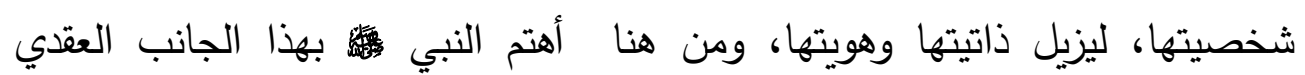

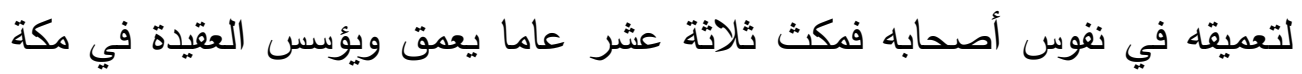

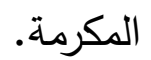

ولذلك قال الإمام / الحسن البصري إنهان: ( إن الإيمان ليس بالتحلي ولا بالتمني،

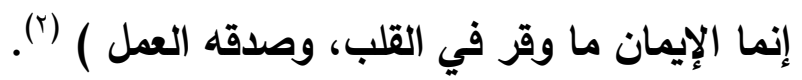

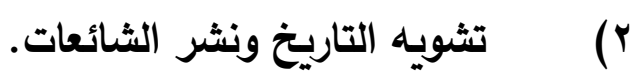

لقد أسهم المستشرقون في تحريف التاريخ تحصينا لمثقفي الغرب، وتثبكيكا

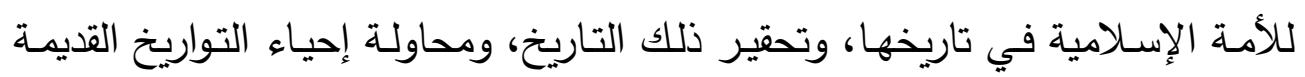

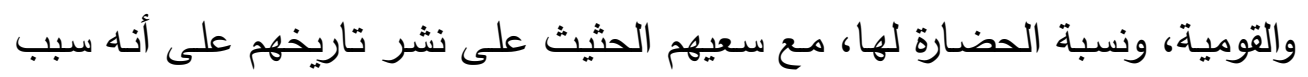
الحضارة، وتعظيمه، وقد ساهم في ذلك الكثير من المنسلخين ممن يتحدثون بألسنتنا،

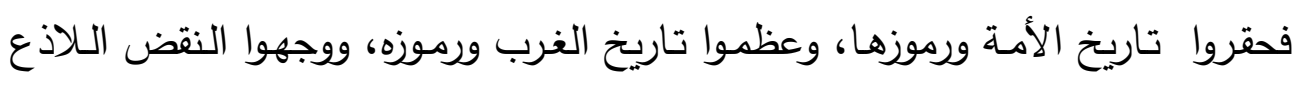

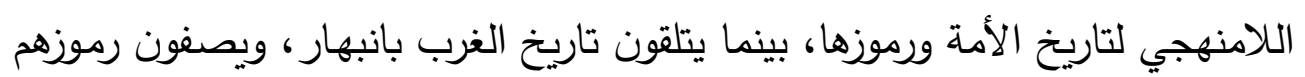

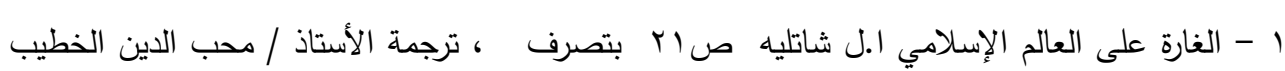

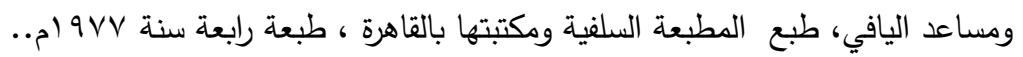

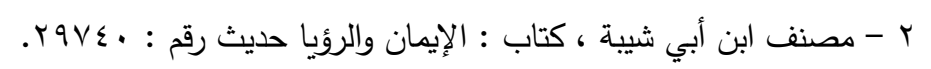




\section{الهوية الإسلامية (روية تأصيلية في ضوء التحديات المعاصرة)}

برموز التتوير ، ويصفون عصور الإسلام بالظلمة والتخلف. وهذا يعلل لنا عطف حكومات الاحتلال الغربية على كل مشاريع الحكومات الوطنية في الثرق الإسلامي والعربي منه خاصة التي من شأنها تقوية الثعوبية فيها، وتعميق الخطوط التي تفرق بين هذه الأوطان الجديدة، مثل الاهتمام بتدريس التاريخ

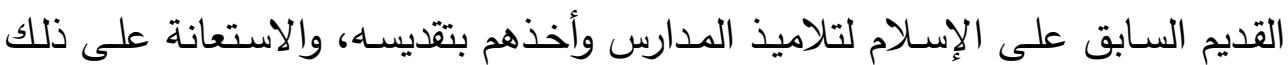

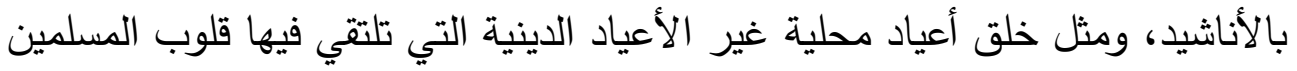

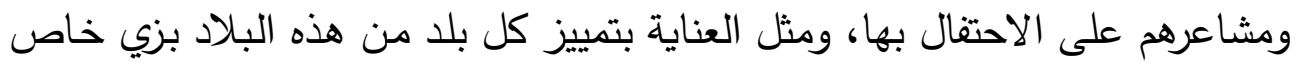

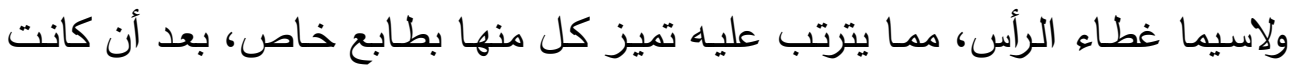

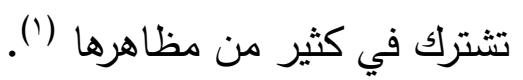

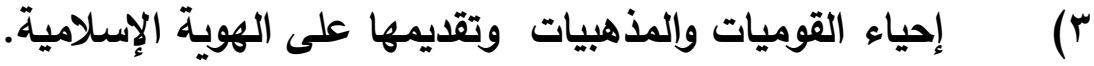
لقد حاول أعداء الإسـلام إحياء القوميات والمذهبيات بين المسلمين، بشتى الطرق والوسـائل التي تعدل على تمزيق وحدتهم وتنكيك أواصـرهم وتثتيت كلمـاتهم، وإحياء

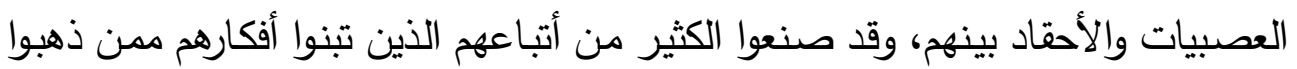

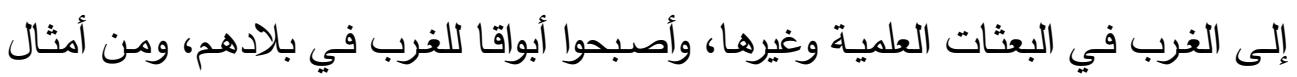
هؤلاء: طه حسين ورفاعة الطهطاوي وقاسم أمين، وغيرهم.

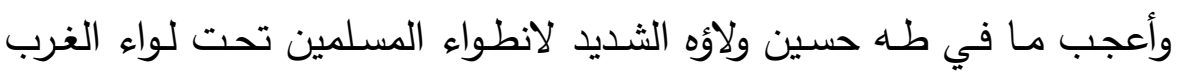

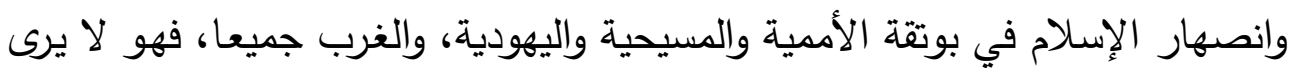

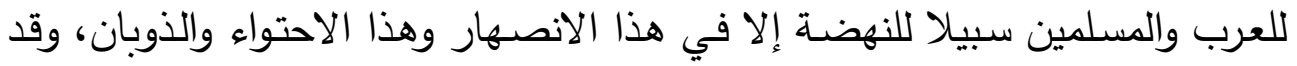

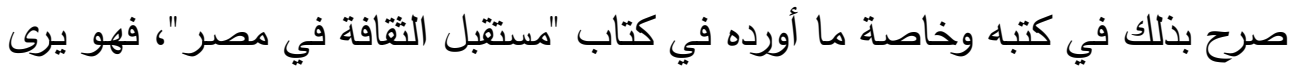
أن العرب قوم مستعمرون كالرومان والفرس (r)

1 - الاتجاهات الوطنية في الأدب المعاصر : د ـ ـ محمد محمد حسين ، نقلا عن أساليب الغزو النكري د.

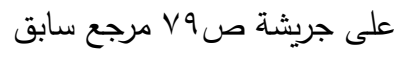
r - أساليب الغزو الفكري للعالم الإسلامي : د د . علي محمد جريثة وأخر ص r م مرجع سابق. 


\section{الهوية الإسلامية (روية تأصيلية في ضوء التحديات المعاصرة)}

إن الدعوة إلى القوميـة وإن كـان الغرب يعتبره مصدر القوة، فهي في الأمسة

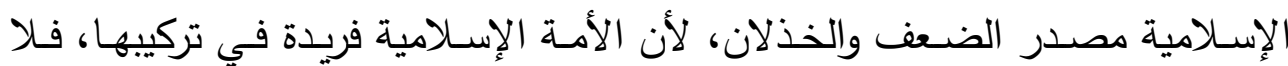

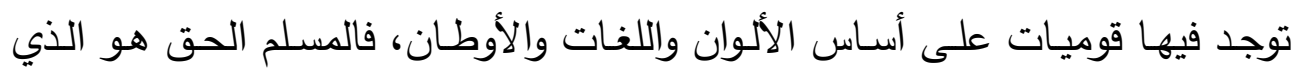

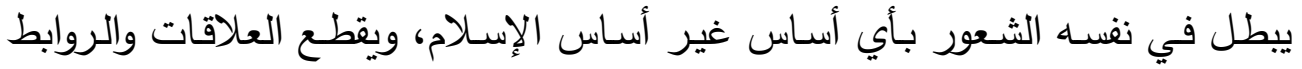

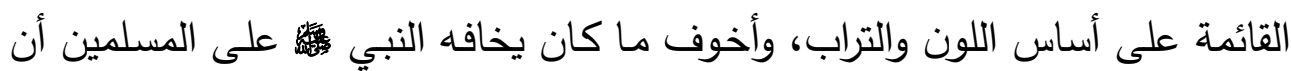

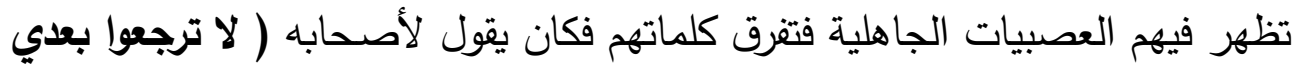
كفارا، يضرب بعضكم رقاب بعض ) (').

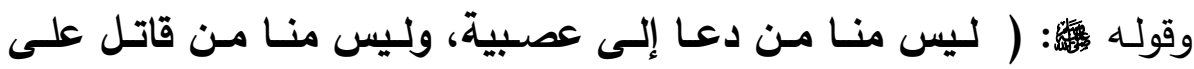
عصبية، وليس منا من مات على عصبية ) (؟).

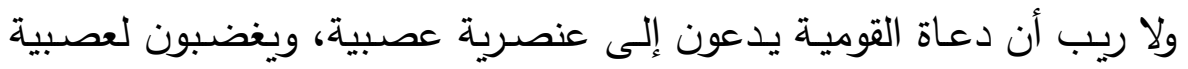
ويقاتلون على عصبية، ولا ريب أيضا أن الدعوة إلى القومية تدعو إلى البغي والفخر ، إندربه وهي فكرة جاهلية تحمل أهلها على الفخر بها والتعصب لها لها (").

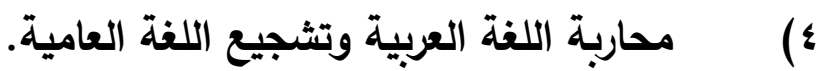

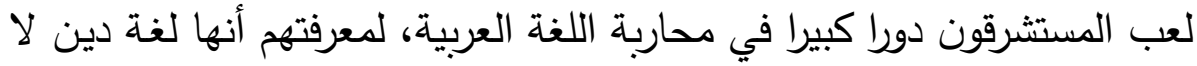
لغة قومية، وبضياعها يفقد المسلمون فهم مصادر تشريعهم، وقد اتخذوا في حربهم

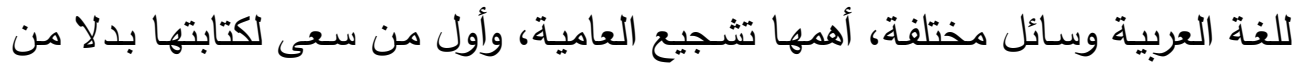

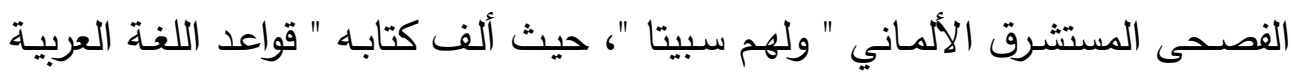
العامية في مصر " وسعى لإثارة العرقية، لأنه ذكر في كتابه أن لغة مصر الأصلية

1 - صحيح البخاري ، كتاب العلم ، باب:الإنصات للعلماء ، حديث رقم : • ب ا.

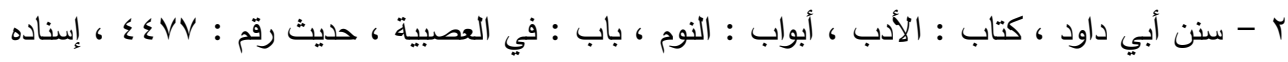
ضنعيف

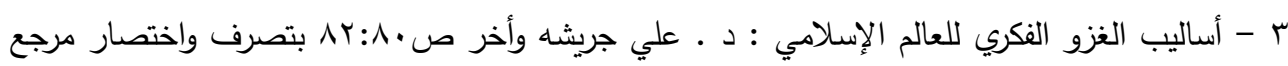
سابق 
الهوية الإسلامية (روية تأصيلية في ضوء التحديات المعاصرة)

هي القبطية وليست العربية، ويحاولوا أن ينسبوا تخلق القوميات باللغة العربية، وسعى الفي

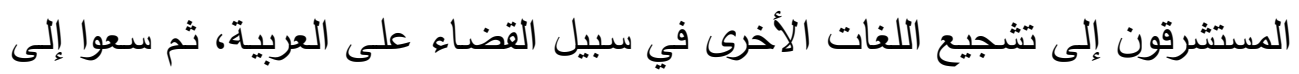

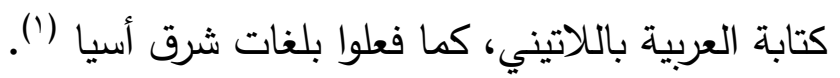

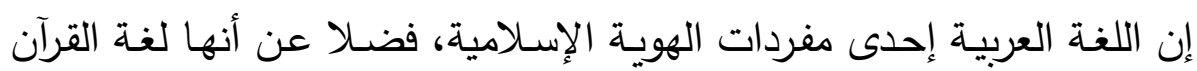
الكريم، وقد وحدت الأمة طيلة تاريخها. ويبين ابن خلدون مكانـة اللغـة العربيـة في الإسـلام، وصلتها الوثيقة بالأمــة

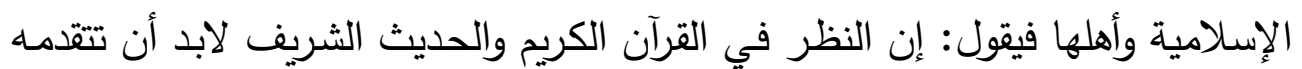

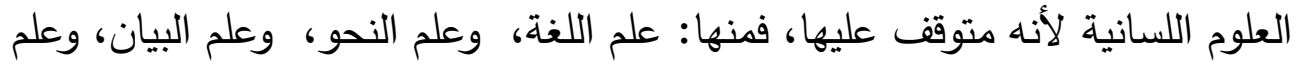
الأدب، وهذه العلوم النقلية كلها مختصة بالأمة الإسلامية وأهلها (r). وقد تفشت ظواهر إهمال اللغة العربية في السنوات الأخيرة بشكل ينذر بالخطر

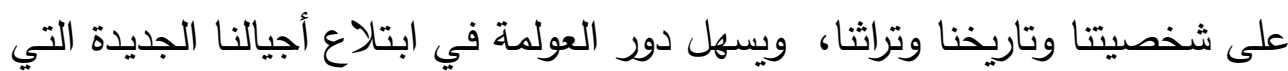

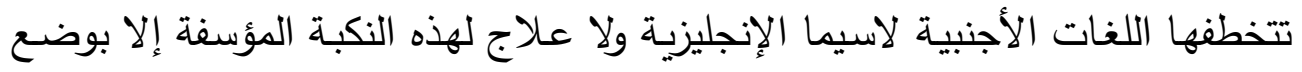

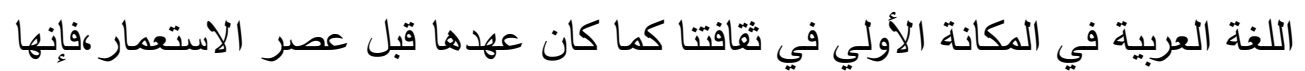

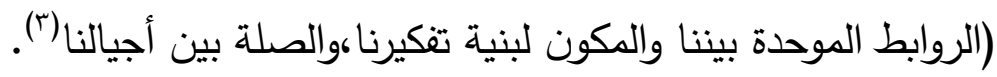

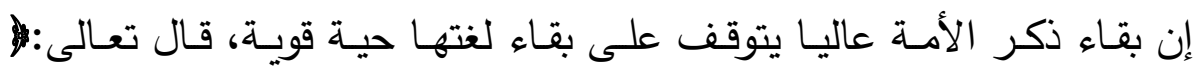

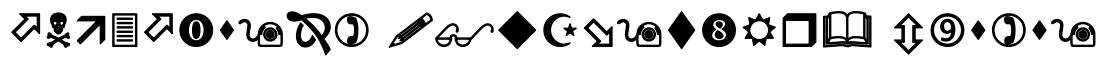

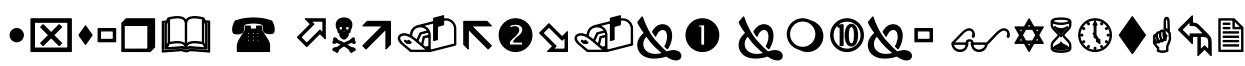
. . . الأنبياء 囚魚人

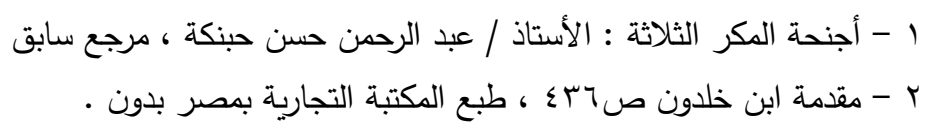

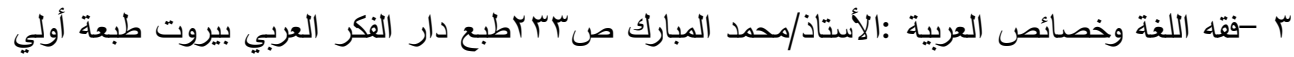

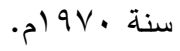


الهوية الإسلامية (روية تأصيلية في ضوء التحديات المعاصرة)

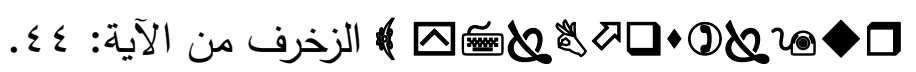

يقول الثيخ / عبد الجليل عيسى: ولهذا كان أقوى سـلاح لخصوم الإسـلام

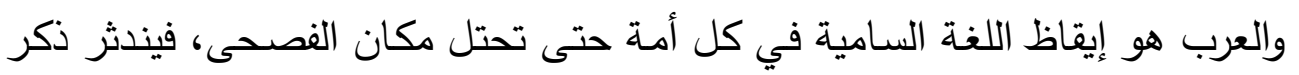

العرب وشرفهم، وينخفض صيتهم وتنقطع صلة المسلمين كافة بكتابهم (').

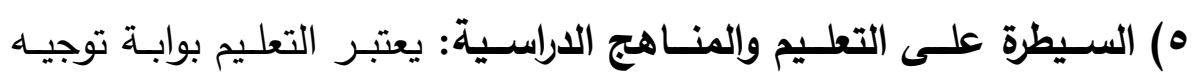

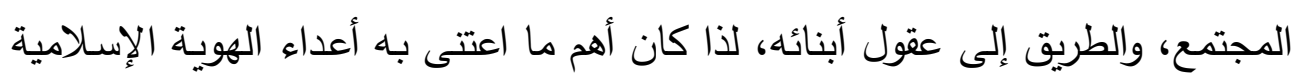

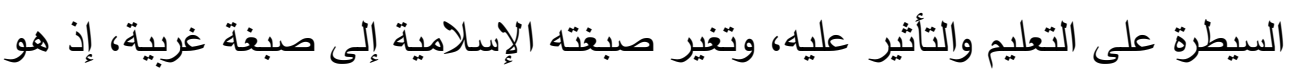
الحصن الأخير الذي يحافظ على هوية النشء ويوجاه مسيرة الأمة.

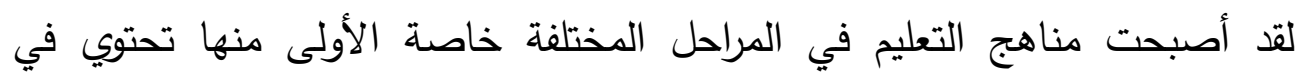

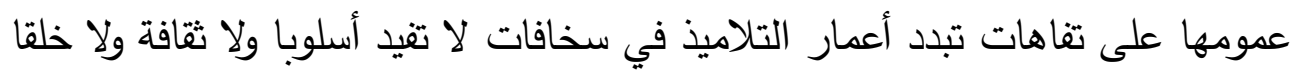

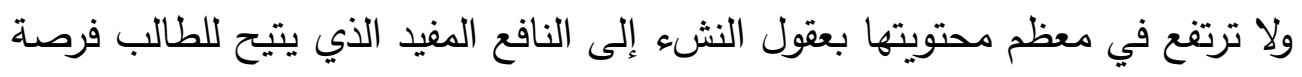

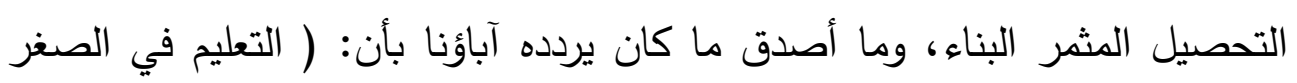

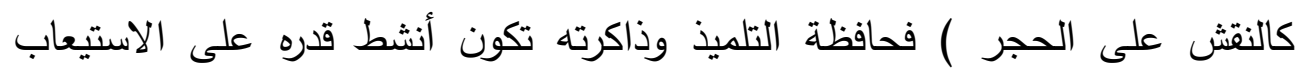

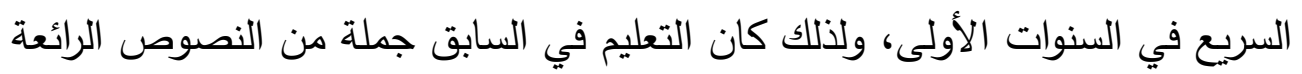

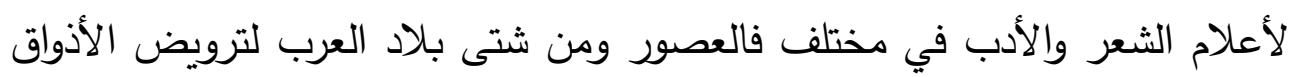

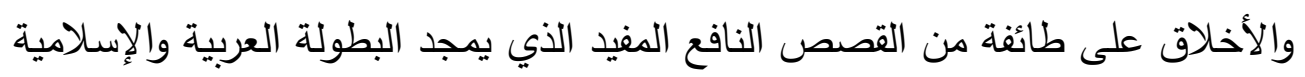

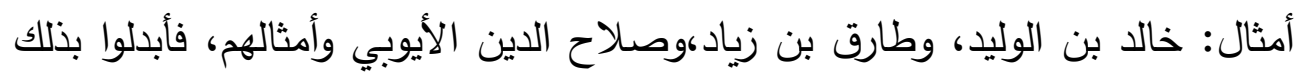

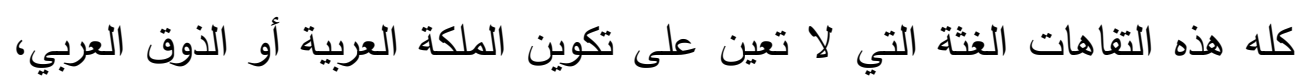

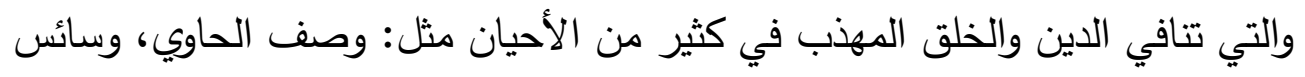

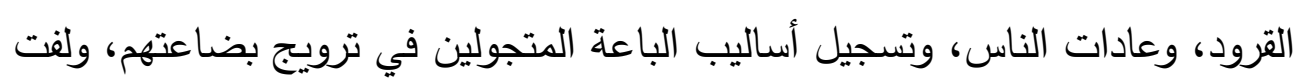

1 - المصحف الميسر : الثيخ / عبد الجليل عيسى صبr ، طبع دار الثروق بالقاهرة ، طبعة اولى سنة 


\section{الهوية الإسلامية (روية تأصيلية في ضوء التحديات المعاصرة)}

المشترين إليهم، وحجة واضعي هذه المناهج تتحصر في أنهم يقدمون للنشء ما يلائم عقولهم وتفكيرهم، وأنهم يتجنبون تكليفهم حفظ ما لا يستطيعون تدبره وفهمه، وهذه إنها

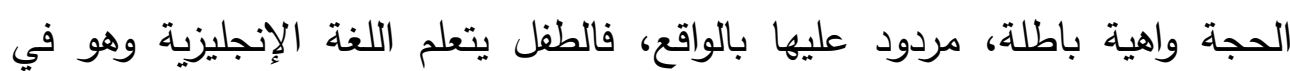

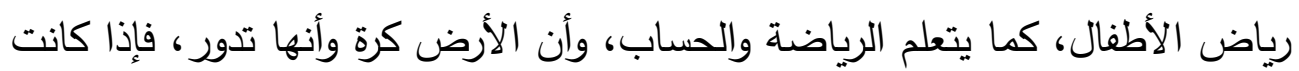

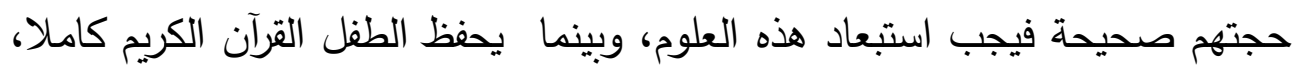

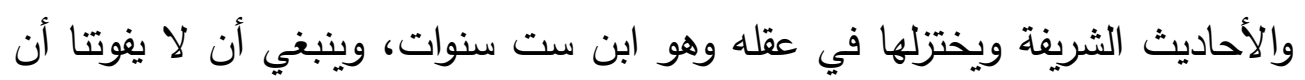

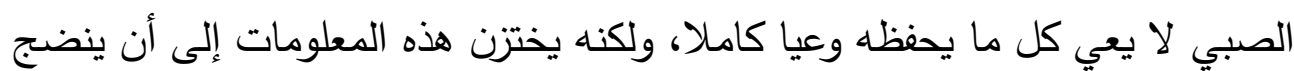
عقله، فيستخرج هذا المدخر شيئا فشيئا ويتدبره ('). ومن هنا حرص المستعمر على السيطرة على التعليم، وتولية العملاء عليه،

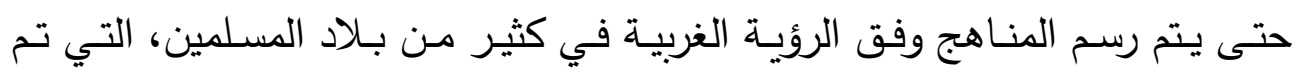

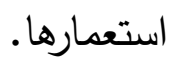

لقد اقترح طه حسين في كتابه " مستقبل الثقافة في مصر " إنثاء لونين من ألوان الدراسة في كلية الآداب، وكان المشروع الأول يدعو إلى إنشاء معهد للأصوات

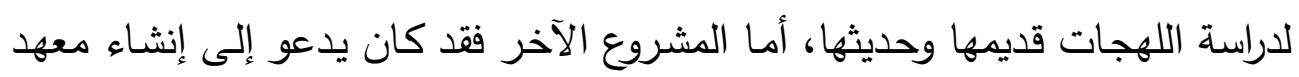

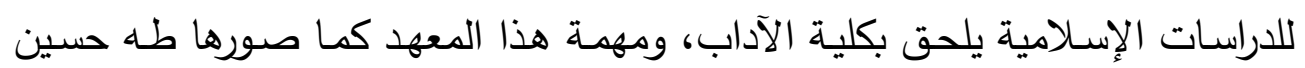
هي العناية بالدراسات الإسلامية على نحو علمي صحيح، والمبرر لإنشائه عنده هو لإنها

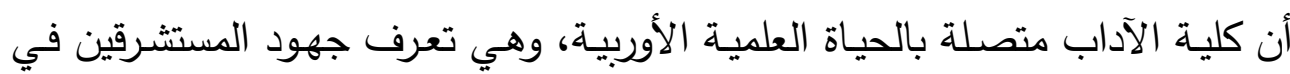

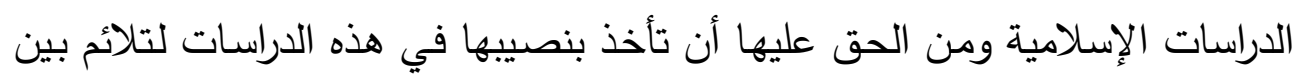
جهود مصر التي ترى لنفسها زعامة البلاد الإنسلامية، وببين جهود الأمم الأوربية (؟).

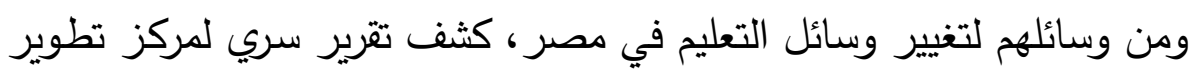

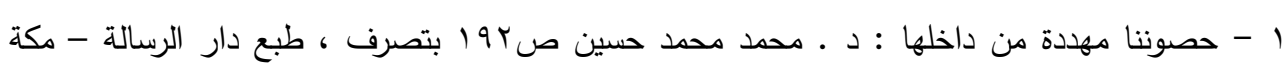

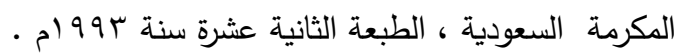

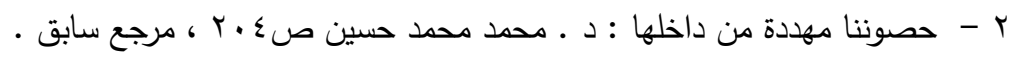




\section{الهوية الإسلامية (روية تأصيلية في ضوء التحديات المعاصرة)}

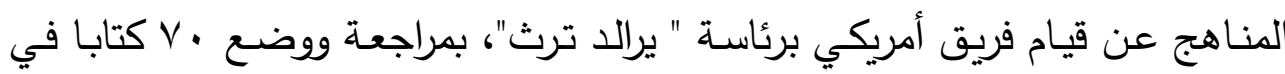

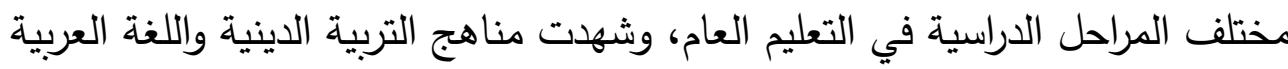
حذف . r\% منها بحجة حذف الحشو. إن الغزو الفكري من بوابة التعليم ركز على العناصر الأساسية فيه، حيث ركز

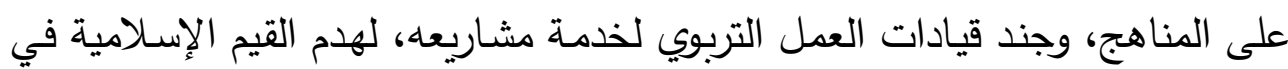
نفوس التلاميذ، وزرع القيم الغربية فيها.

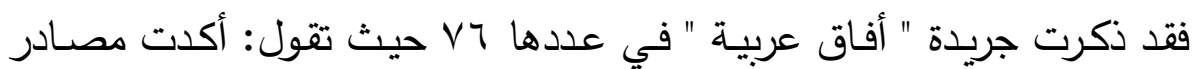

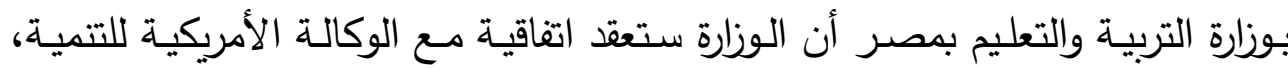

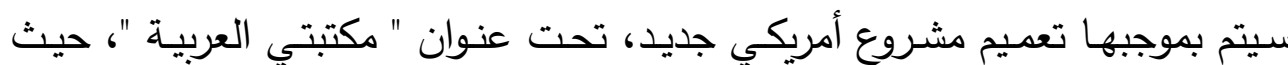

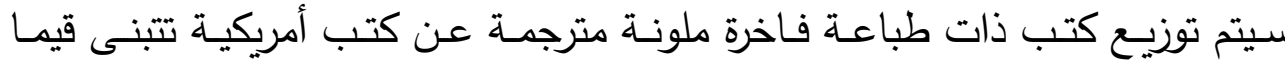

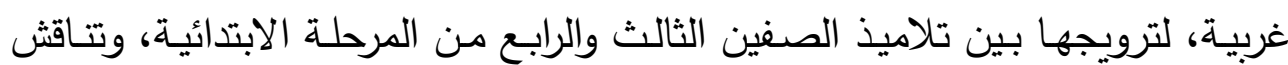
الكتب الموضوعات الجنسية. كما قام مشروع حرب الهوية بمحاربة المعلم الملتزم ومضايقته. وقد قام الغزاة بافتتاح المدارس الأجنبية لتغير هويـة تلاميذها، ومستخ عقولهم لونه ليكونوا أبواقا للغرب. يقول اللورد" كرومر " في وصف مدرسة فيكتوريا:( أبناء مدرسة فيكتوريا سيكونون جسرا بين الثقافة الأجنبية والإسلامية ) في إثارة خبيثة بأنهم سيكونون نسخا مزيفة للهوية الغربية (1). إن التعليم في الإسـلام مـرتبط بالدين، بينمـا هو منفصـل عنـه في المنـاهج

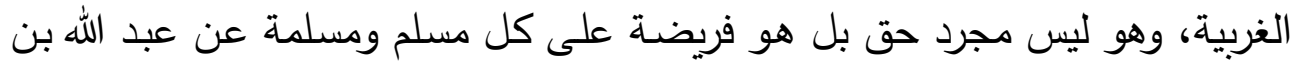

1 - مقال منشور على الثبكة العالمية ، موقع (شبهات) 11028 www.shobohat.com/vp/showthread:php? 
الهوية الإسلامية (روئة تأصيلية في ضوء التحديات المعاصرة)

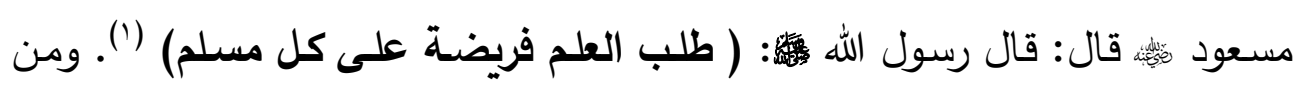

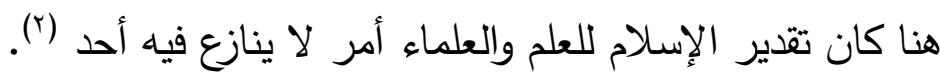

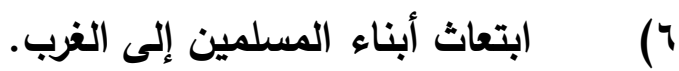

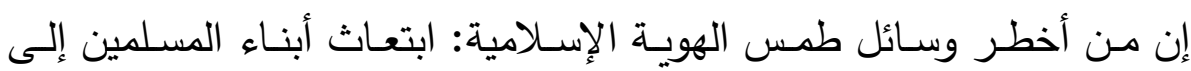

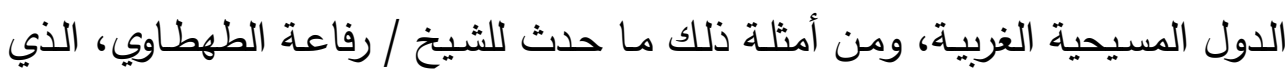

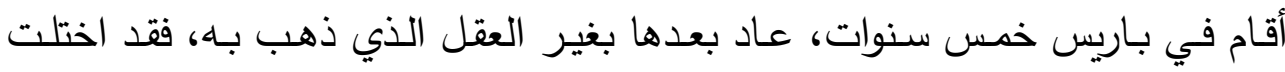

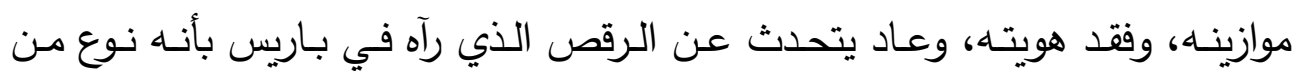

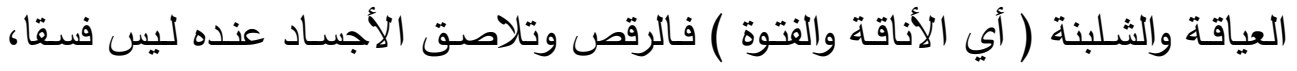

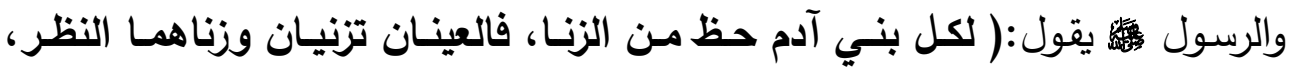

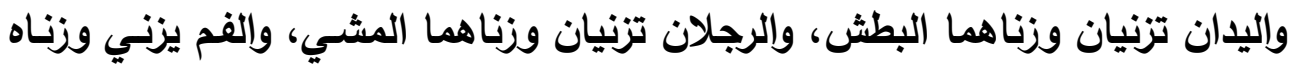

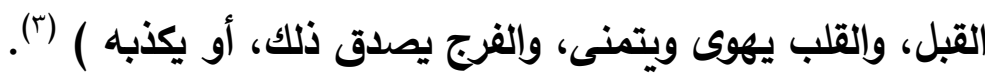

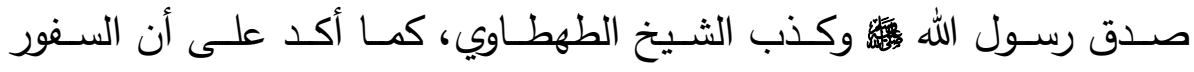
والاختلاط بين الجنسين لا يؤدي إلى الفساد، كما تحدث عن المشاعر الوطنية ليحلها محل الششاعر الدينيـة، وراح يثير الجاهليـة القديمة، فيتحدث عن مصر الفرعونية،

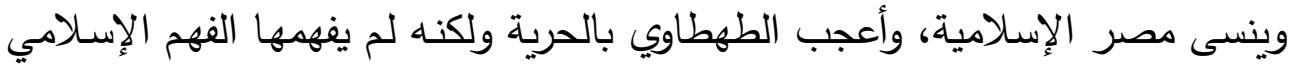
الذي تتحقق بـه عبوديـة المسلم لله وحده، ويتحقق تحرره من كل عبودية سوى الله،

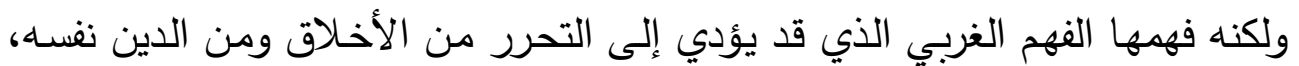
وقس على الشيخ من ذهبوا بعده (؛).

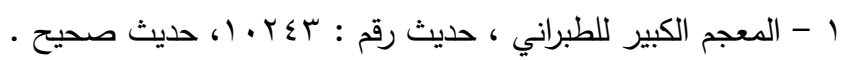

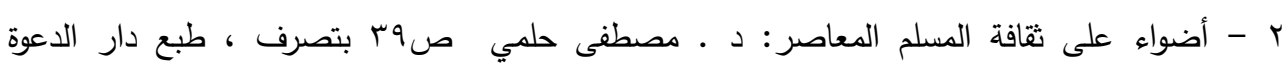
بالإسكندرية ، طبعة أولى سنة الوبه 999 ام.

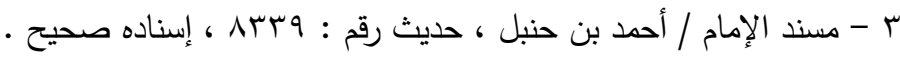

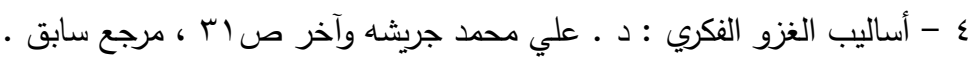




\section{الهوية الإسلامية (روية تأصيلية في ضوء التحديات المعاصرة)}

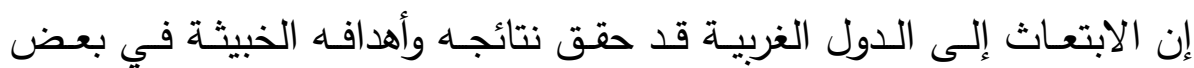

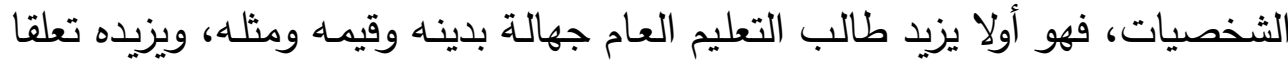
بقيم الغرب أو الثرق ومثله، وهو من ناحية أخرى يبدأ بتطبيعه بطباع غير بلدئ إسلامية،

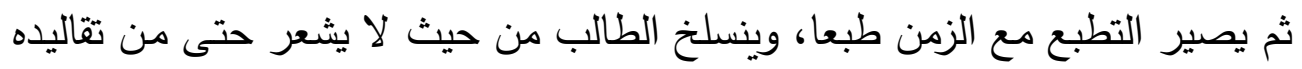

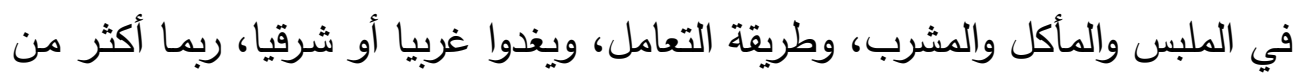

$$
\text { الغربي أو الثرقي. }
$$

وفي هذا المعنى يقول أحد الكتاب الغربيين: فبينما يترك الحكام الغربيون

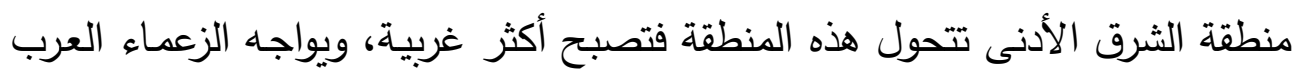

طريقين، فهم يطردون الغرب سياسيا ويسحبون الكتل الشعبية إلى الغرب ثقافيا(').

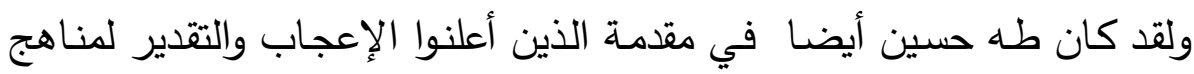
الستشرقين، ويعتبر حامل لواء الدفاع عنهم وعن أهوائهم، وكثيرا ما يقول:عن هذه إنهاب

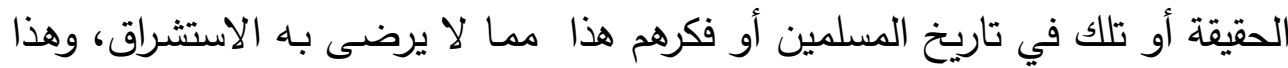

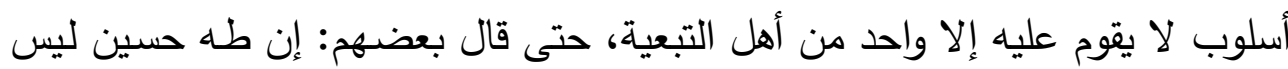

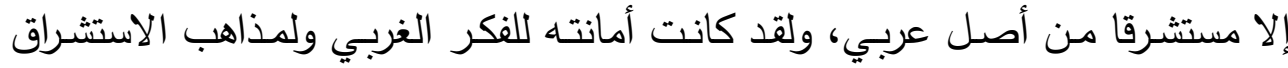

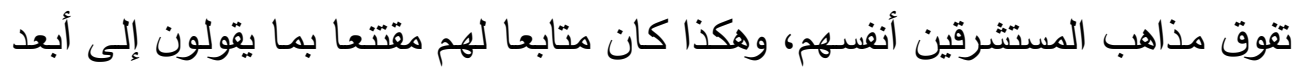

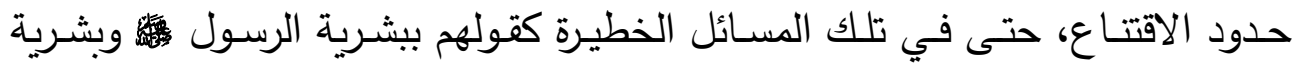

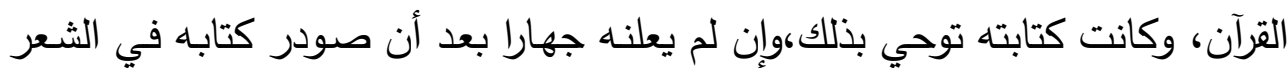

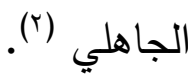
ومثل طـه حسين في التبعيـة: سـلامة موسى، وعلي عبد الـرازق، وحسـين

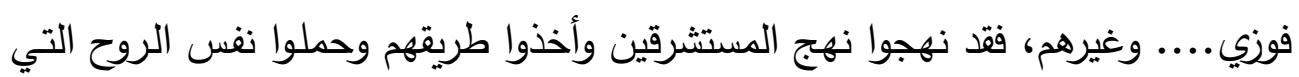

$$
\begin{aligned}
& 1 \text { - المرجع السابق صع } 7 . \\
& \text { r - المرجع السابق ص سזr. }
\end{aligned}
$$




\section{الهوية الإسلامية (روية تأصيلية في ضوء التحديات المعاصرة)}

يحملها أساتنتهم في خصومة الإسلام، وكانوا أشد قوة على أهلهم من الغربيين (').

\section{） السيطرة على وسائل الإعلام.}

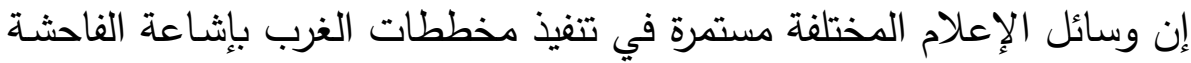

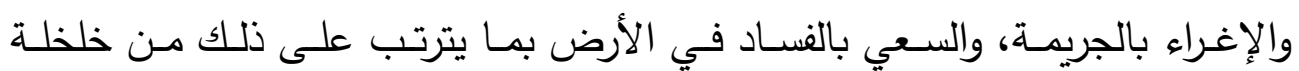

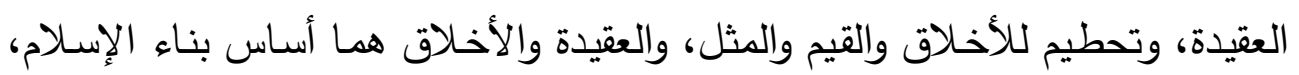
فإذا انهام الإسلام فكيف يقوم البنيان.

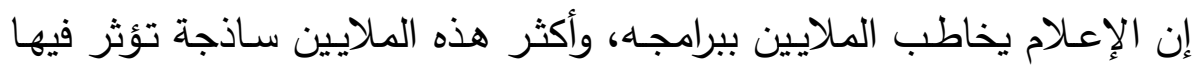
الكلمة سواء كانت مقروءة أو مسموعة أو مرئية، فإن كانت طيبة كانت كثجرة طيبة تبني ولا تهام، وإن كانت خبيثة كانت كثجرة خبيثة تهدم ولا تبني. إن وسائل الإعلام في الدول الإسلامية قد تردت ولا زالت تتردى عن علم من

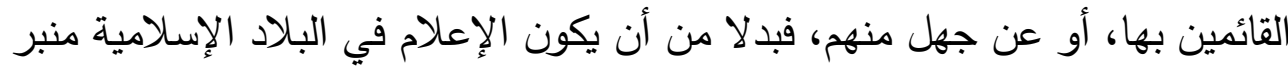

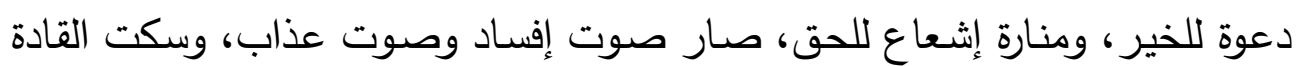
فأقروا بسكوتهم أو جاوزوا ذلك فثجعوا وحموا وزلزل الناس في إيمانهم وقيمهم ومثلهم

ثمار تمسك العالم الإسلامي بالهوية في العصر الحاضر (r)

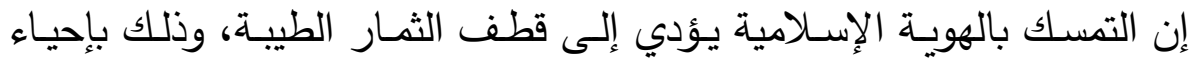

1 - الإسلام في وجه التغريب- مخططات الاستشراق والتثشير : الأستاذ : أنور الجندي ص ساب،طبع دار

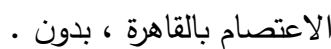

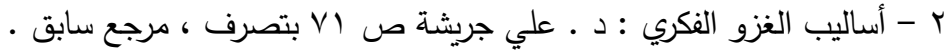

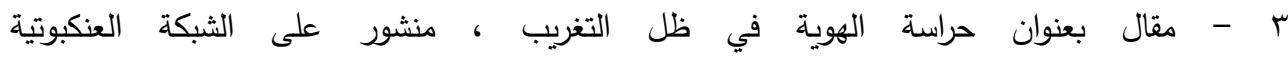
www.shobohat.com/vp/showthread:php?=11028 


\section{الهوية الإسلامية (روية تأصيلية في ضوء التحديات المعاصرة)}

الهوية في نفوس الأجيال المعاصرة، مع تحقيق عزتها وكرامتها بين أمم العالم، كما

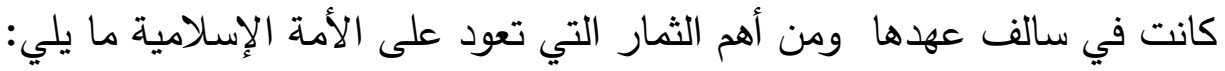

\section{1- تحقيق التوحيد الخالص لله تعالى .}

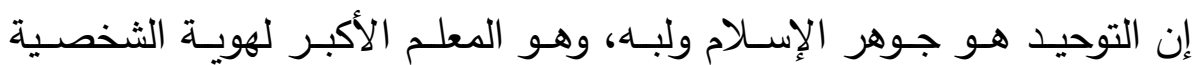

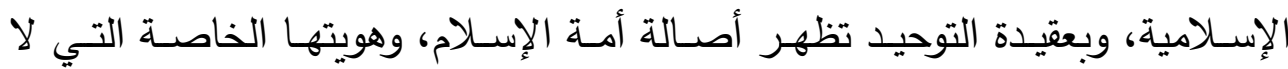

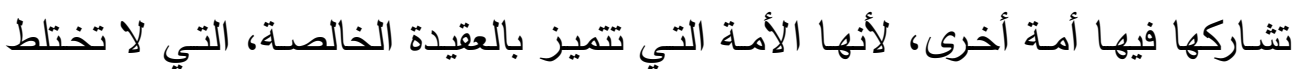

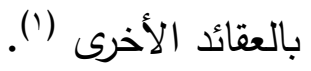
إن أعظم العدل هو التوحيد، كما أن أعظم الظلم هو الثرك بالله تعالى، وقد

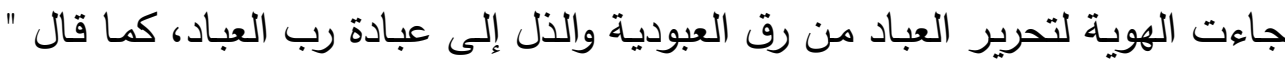

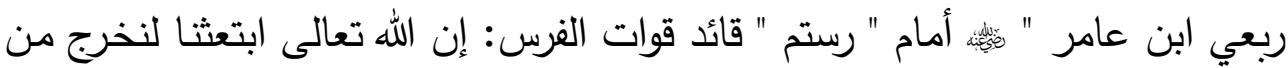

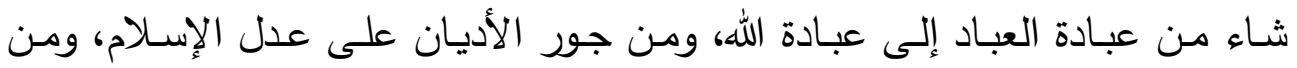

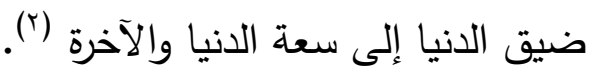
ومن قول هذا الصحابي الجليل تظهر أعظم ثمار الهوية الإسلامية التي تحقق

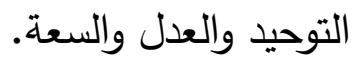

r- تحقيق التمكين للأمة الإسلامية .

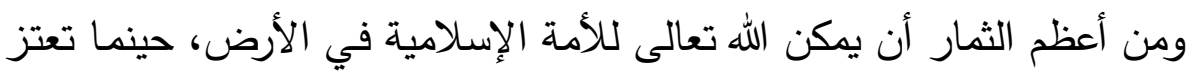

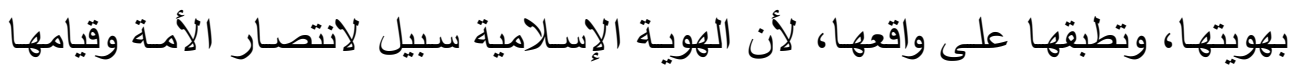

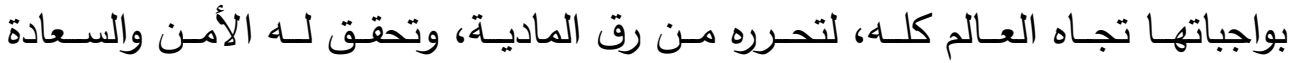

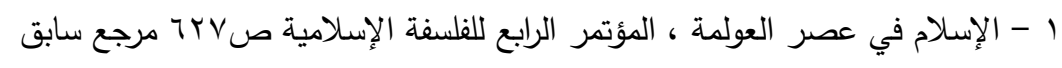

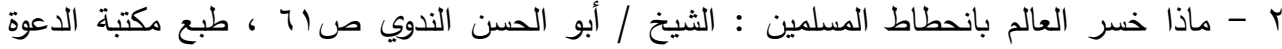
الإسلامية ، طبعة سادسة سنة 970 (م. 
الهوية الإسلامية (روية تأصيلية في ضوء التحديات المعاصرة)

والطمأنينة التي يفتقدها،

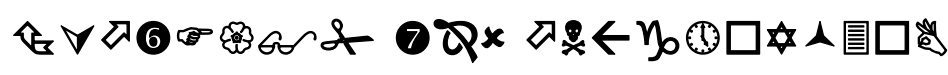

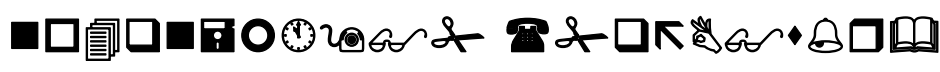

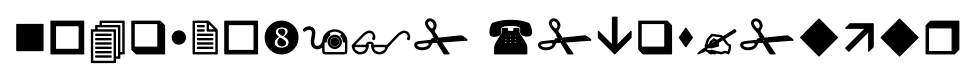

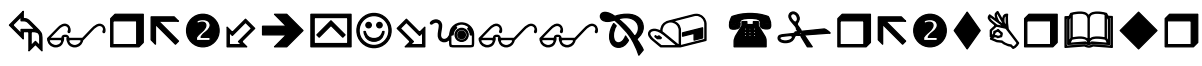

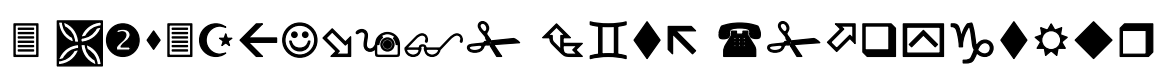

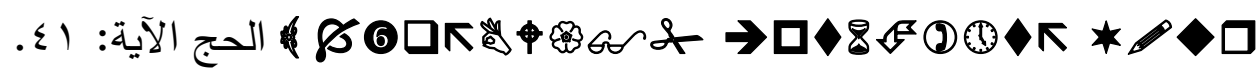
يقول الأستاذ / سيد قطب:

هؤلاء هم الذين ينصرون الله، إذ ينصرون نهجئه الذي أراده للناس في الحياة،

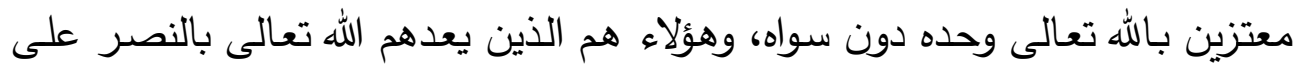

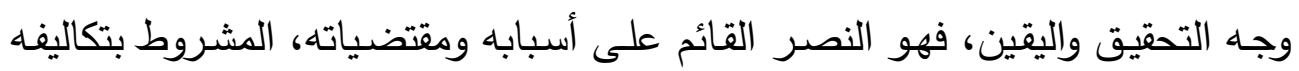

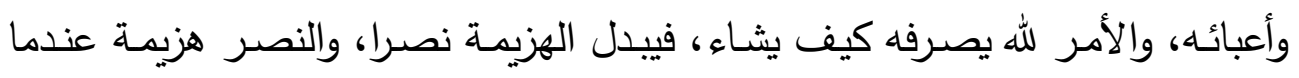

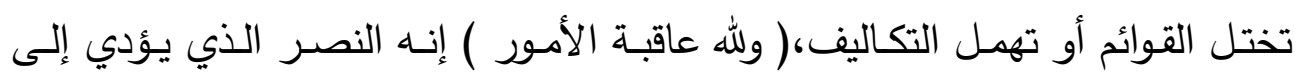

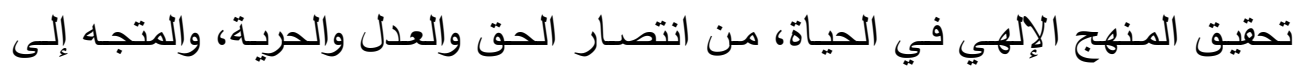

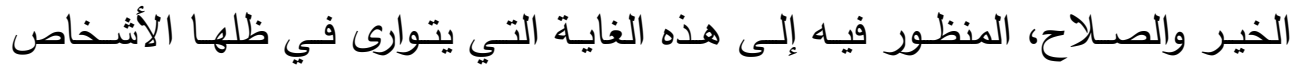

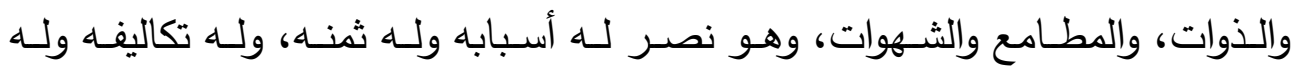

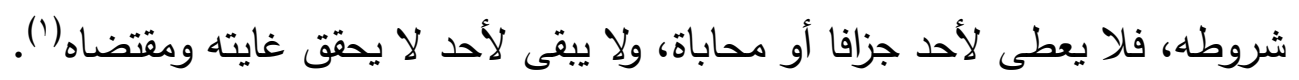

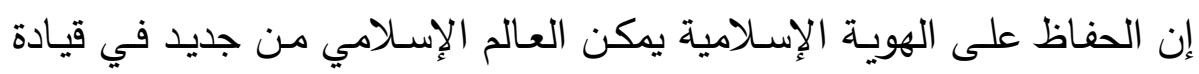

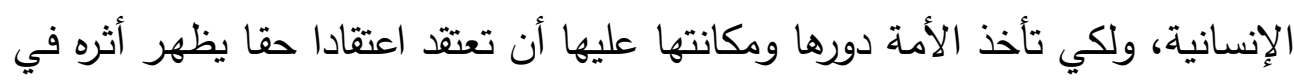

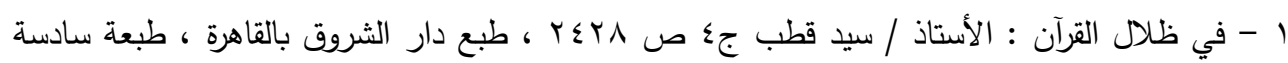

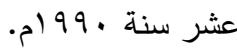




\section{الهوية الإسلامية (روية تأصيلية في ضوء التحديات المعاصرة)}

كل أقوالها وأفعالها أن دينها هو الدين الحق الخالص الصحيح، وعليها أن تتصكك بمصادر عزتها وقوتها وريادتها وخصوصيتها التي تميزها بين أمم العالم، فقد أعزنا الله

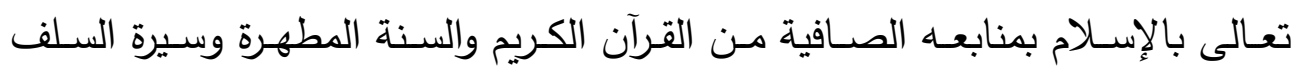

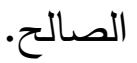

إن المسلم لم يخلق ليندفع مع التيار ويساير الركب البشري حيث اتجه وسار، بل خلق ليوجها العالم والمجتمع والمدنية، ويفرض على البشرية اتجاهـ ويملي عليها

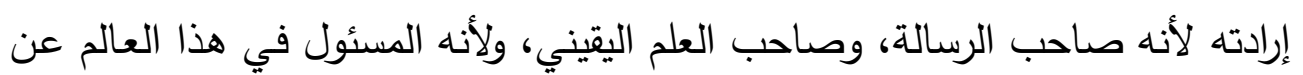

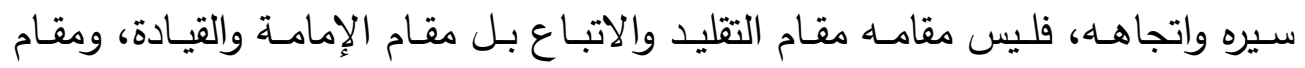

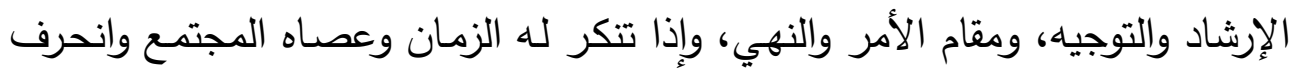

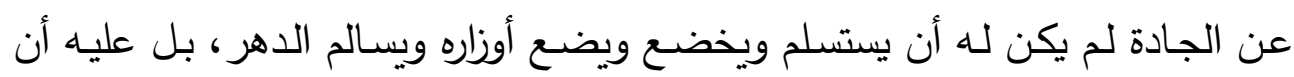

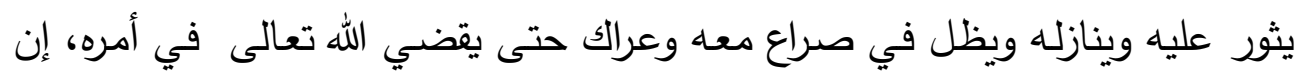

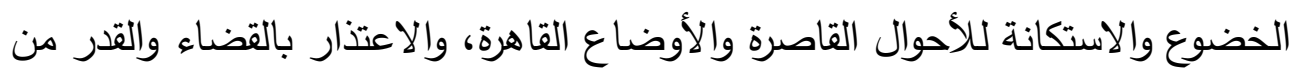

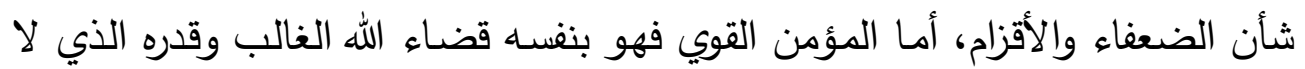

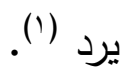
إن قيام الأمة وحفاظها على هويتها من أعظم أسباب تمكينها في الأرض، واستعادة عزتها وكرامتها بين أمم العالم.

\section{r- تحقيق الوحدة الإسلامية.}

إن الوحدة الإسـلامية من أهم الثمار التي تعود على الألمـة لتمسكها بهويتها

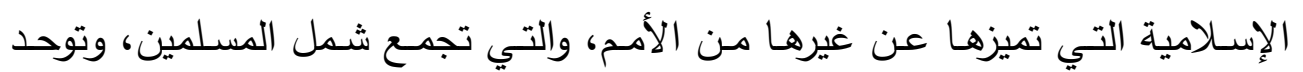

1 - ماذا خسر العالم بانحطاط المسلمين : الثيخ / أبي الحسن علي الحسيني النذوي ص 9 بتصرف مرجع • سابق 
الهوية الإسلامية (روية تأصيلية في ضوء التحديات المعاصرة)

كلمتهم وتئلف بين قلوبهم مههـا اختلفت أوطانهم ولغاتهم وأجناسـهم وبيئاتهم، فإن

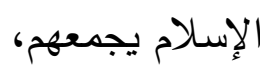

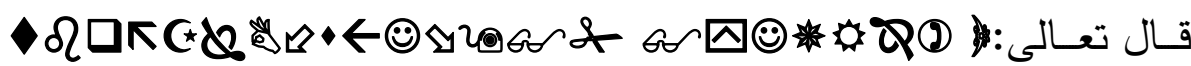
(1) الحجرات من الآية: 1.

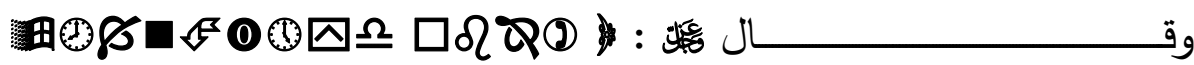

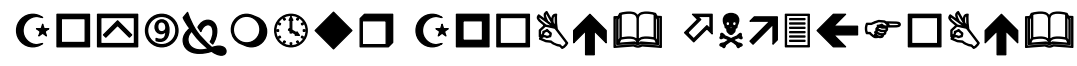

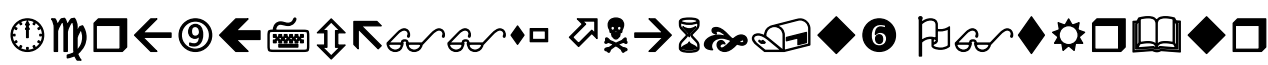
(الأنبياء: 94. وقـ

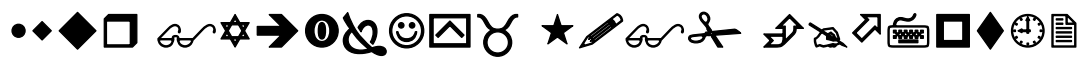

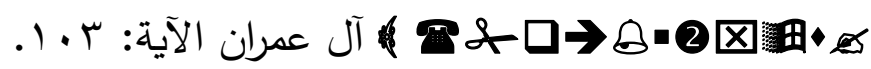

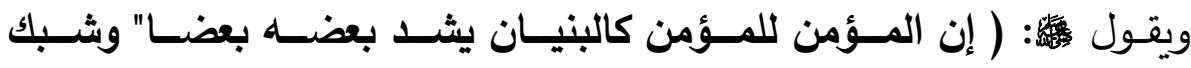
(أصابعه) (') (2) (2) وقال

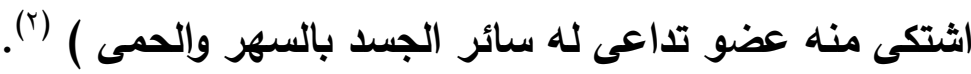

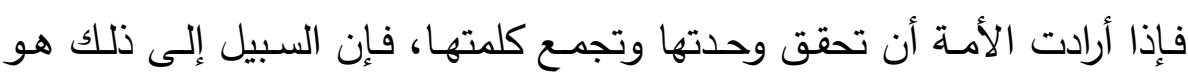

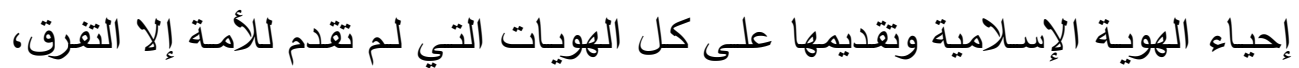
والتي يغرسها العدو، ويسعى لأحيائها.

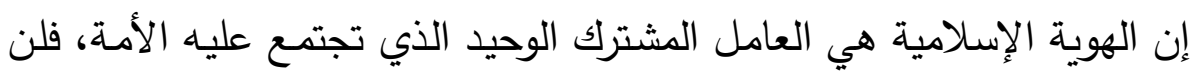

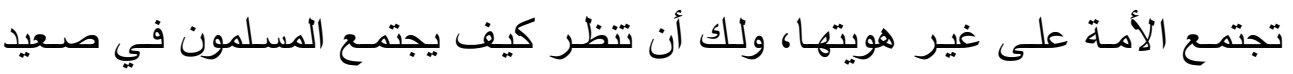

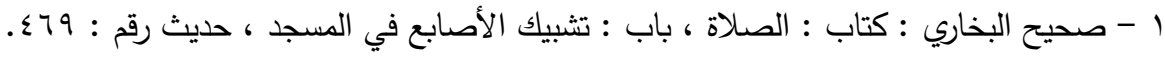

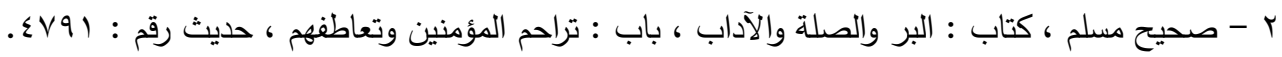




\section{الهوية الإسلامية (روية تأصيلية في ضوء التحديات المعاصرة)}

عرفات مع اختلاف هويتهم القومية والعرقية والجغرافية، إلا أن كلمة التوحيد تجمعهم.

\section{ـ - تحقيق النهضة الثاملة .}

لقد ازدهرت حضارة المسلمين الأوائل ونهضوا في شتى العلوم والمعارف التي

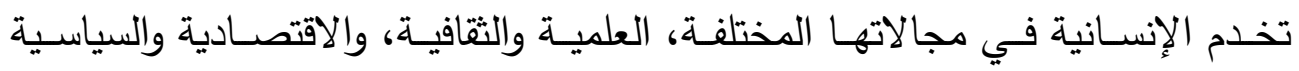
والفكرية وغيرها، وذلك حينما تمسكوا بعقيدتهم وهويتهم وحققا إسلامهم وتعاليم دينهم

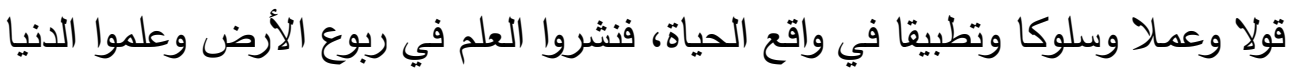
كلها، ولا زالت علومهم حتى اليوم يتعلم منها الثرق والغرب.

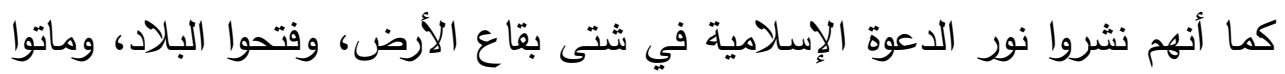

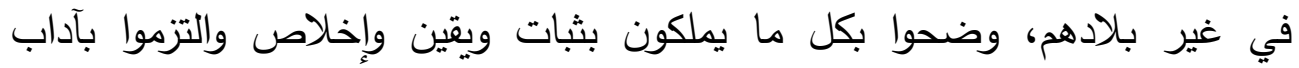

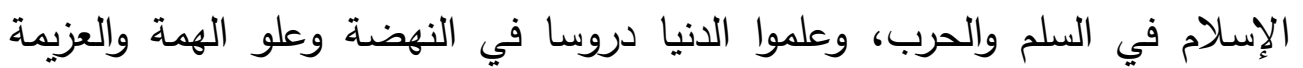
والفذاء، كما حققوا العدل والقناعة، واختلطوا بكل المجتمعات والأمم، وجلس علماء وعلاء الغرب تحت أقدامهم يتعلمون العلوم المختلفة، فلم يضنوا ولم يبخلوا بشيء، ونشروا

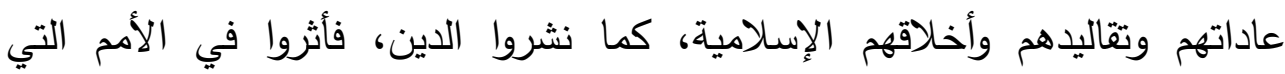

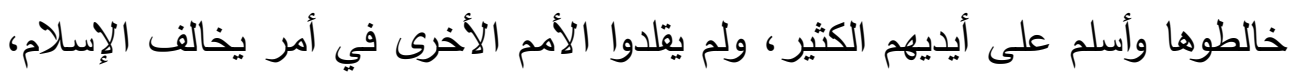

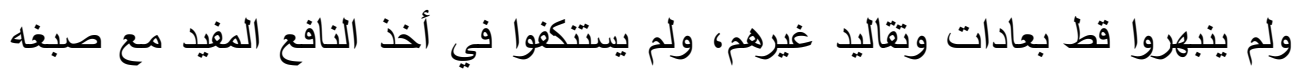

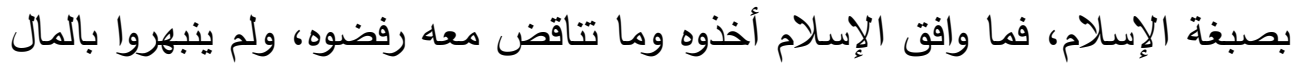

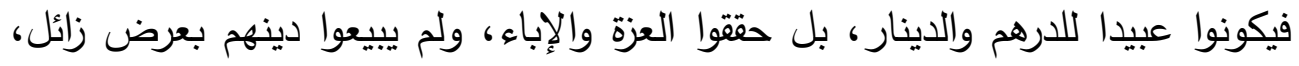

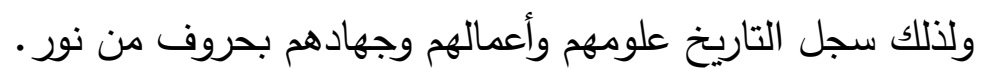

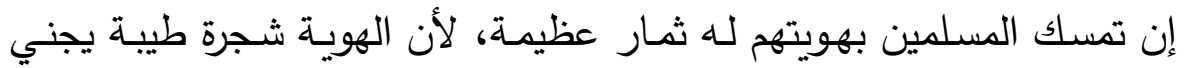

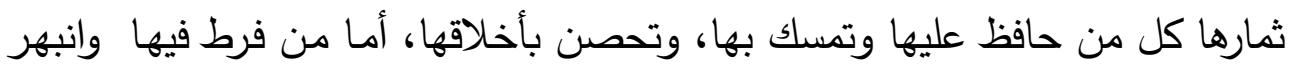

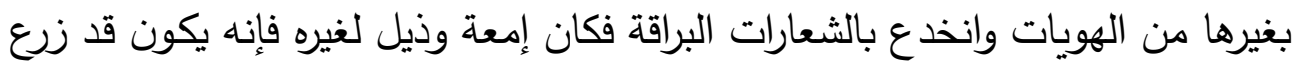
شجرة خبيثة في نفسه يتجرع مرارتها. 
الهوية الإسلامية (روية تأصيلية في ضوء التحديات المعاصرة)

ولهذا قال النبي

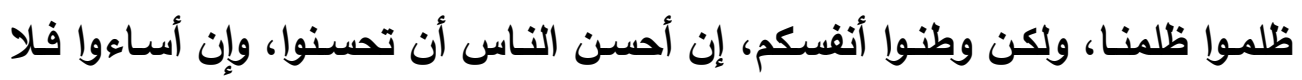
تظلموا ) (')

فالمسلم صاحب شخصية قيادية لها خصوصيتها ومقوماتها، لأنه يدين بدين

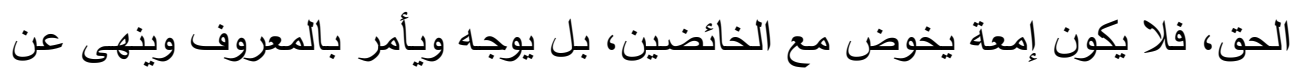

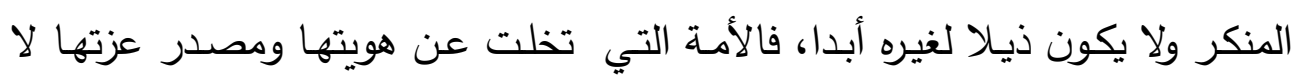

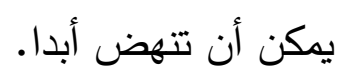

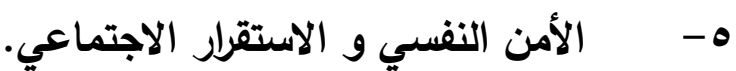

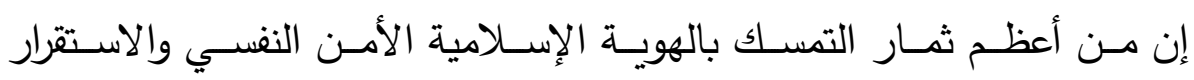

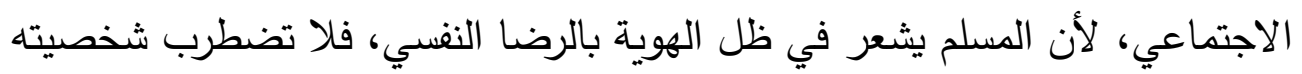

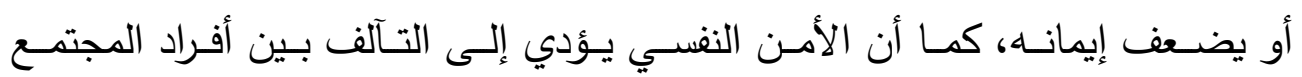

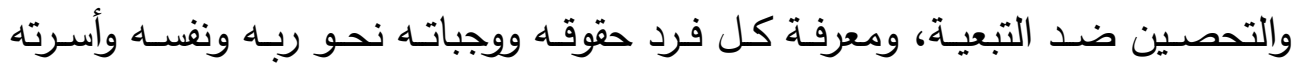

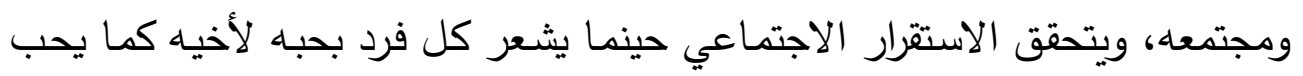

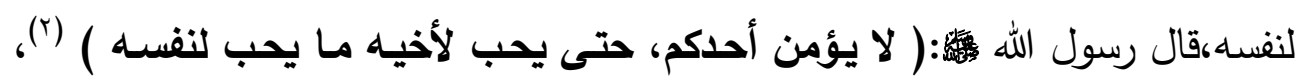

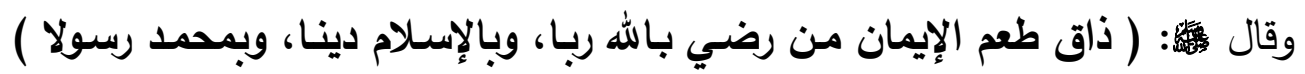

ويتحقق الرضا النفسي والسكينة والأمن للمسلم إذا رضـي بالله ربـا وبالإسـلام

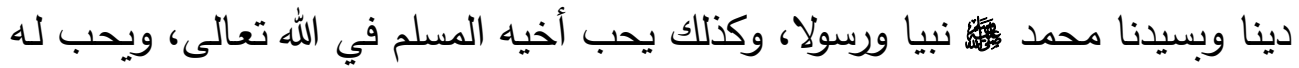
ا - سنن الترمذي ، كتاب : الذبائح ، أبواب البر والصلة ، باب : ما جاء في الإحسان والعفو ، حديث رقم . $19 V 9$ : r - صحيح البخاري ، كتاب : الإيمان : باب : من الإيمان أن يحب لأخيه ما يحب لنفسه ، حديث رقم : r - صحيح مسلم ، كتاب : الإيمان ، باب : ذاق طعم الإيمان من رضي بالله ربا ، حديث رقم : عV. 
الهوية الإسلامية (روية تأصيلية في ضوء التحديات المعاصرة)

الخير كما يحبه لنفسه.

أمسا إذا ضـعف الإيمـان في القلب وتزعزعت هويـة المسلم فإنـه تقل مناعتهـ وحصانته ويكون مهيأ للتبعية والتقليد ومن هنا يفقد المجتمع استقراره باضطراب أفراده،

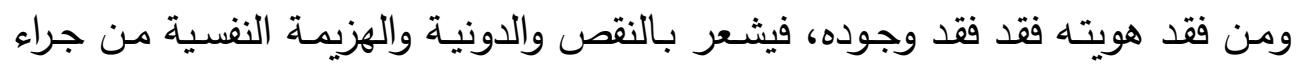

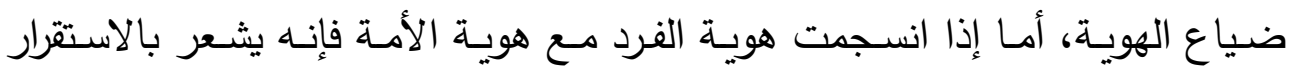
والاطئنان. 


\section{الهوية الإسلامية (روية تأصيلية في ضوء التحديات المعاصرة)}

$\ddot{a}$

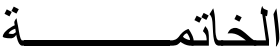

الحمد الله الذي بنعمتهه تـتم الصـالحات، والصـلاة والسـلام على المبعوث رحمـة

للعالمين، سيدنا محمد صلى الله عليه وعلى آله وصحبه، ومن سار على نهجه إلى يوم الدين.

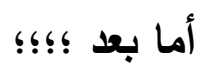

فقد طوفنـا في هذا البحث، الذي يـدور حـول الهويـة الإسـلامية، والذي هـو موضوع الساعة في العصر الحاضر ؛ لأنه يعيد للأمة الإسلامية شخصيتها وجوهرها ووجودهـا الحقيقي، ويحقق لها الأمـن والأمـان والسـعادة، ويضـع قدمها على الطريق المستقيم، كمـا يعمل على رقيها وازدهارهـا في شتى جوانب الحيـاة، ويحصنها ضد التيارات والأفكار المعاصرة.

وسـوف أوجز أبـرز النتائج والتوصـيات التي توصـلت إليهـا مـن خـلال هـا الموضوع الحيوي،وذلك في النقاط التالية:

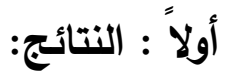

1- - - إن الهويـة الإسـلامية حقيقة واقعيـة لا يختلف عليها اثنان وهي من الأولويات التي يجب الحفاظ عليها لأهميتها وحفظها لكيان ووجود وتحصين المجتمع الإسلامي.

r- - إن التمسك بخصـائص الهويـة يغرس في الأمـة العزة والكرامـة وروح التميز والإبداع ويساعد على مواجهة التحديات التي تحاول تذويبها أو إلغائها والقضاء عليها. r- - إن الانتماء للهوية الإسلامية هو حصن الأمان للأمة ضد الثـاردين من أبنائها الذين يريدون لها أن تكون تابعـة مقلدة منقادة لغيرهـا، ويعملون أبواقـا للغرب ينفذون أفكاره داخل مجتمعهم بهدف طمس الهوية ولذلك يجب الحفاظ عليها بشـتى الطـرق والأسـاليب ضـد الدعوات المغرضــة التي تهـف إلى ضـياع المجتمـع 


\section{الهوية الإسلامية (روية تأصيلية في ضوء التحديات المعاصرة)}

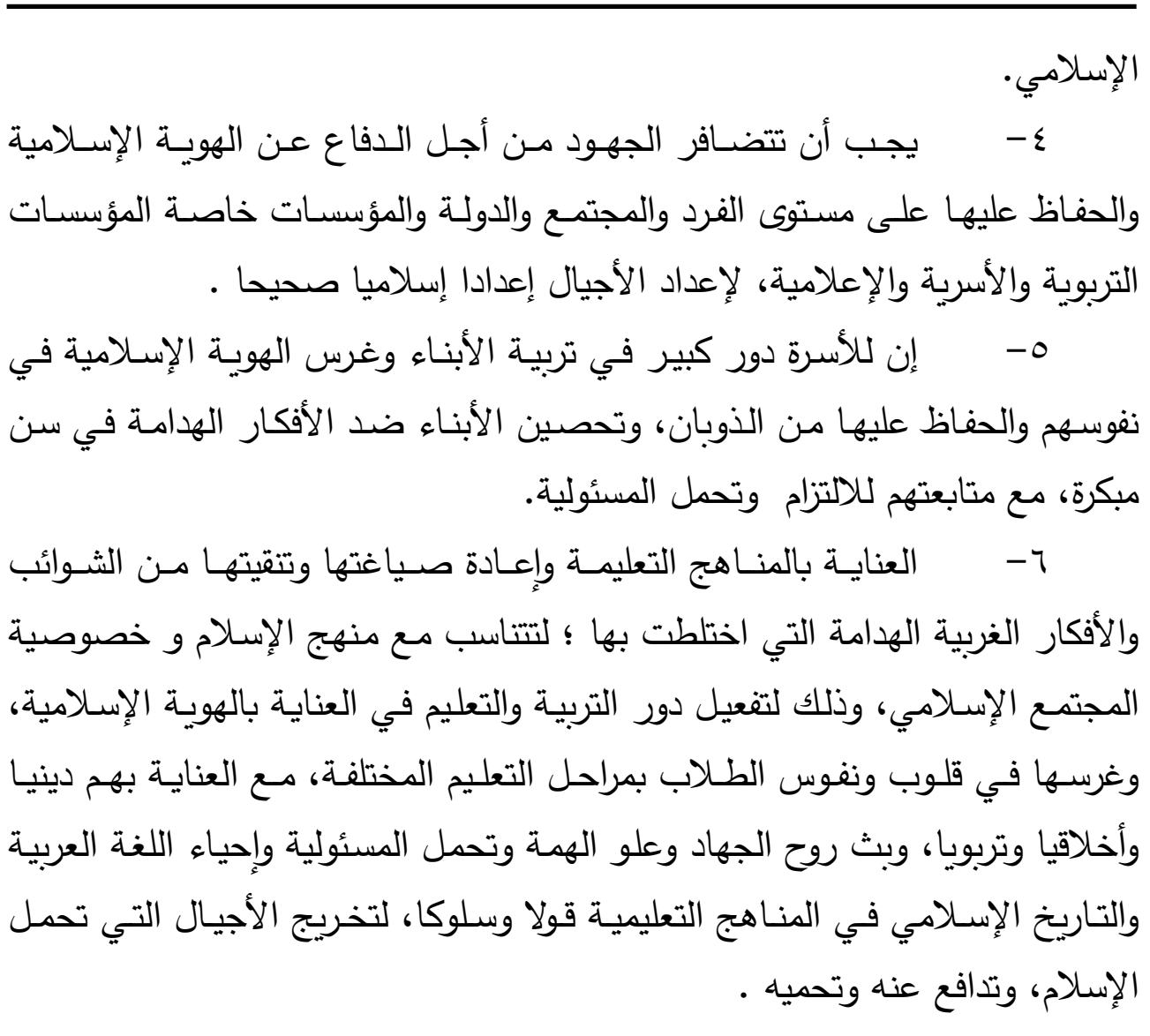

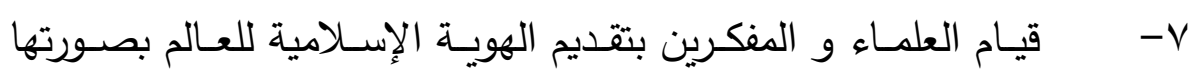
الحقيقية بعيدا عن المفاهيم الخاطئة والأفكار المشوهة التي يبثها الغرب عن طريق وسـائل الإعـلام، كما توجـه الهويـة الإسـامية إلى بلدان العـالم باللغـات المختلفة لكل دولة.

-1 - - إن الدعاة إلى الله تعالى يجب أن يكون لهم دور كبير في الحفاظ على هوية المسلمين، وتحمل المسئولية في توجيه المدعوين، وتحذيرهم من الأخطار التي تؤثر على هويتهم، وتضعف انتمائهم خاصـة الأفكار المغرضـة والغزو الفكري والعولمـة والثبهات المستمرة التي تشكك المسلمين في هويتهم، فيجب تتبعها والرد عليها. 


\section{الهوية الإسلامية (روئة تأصيلية في ضوء التحديات المعاصرة)}

9- - الحرص على أن لا يدفعنا الواقع الأليم الذي تعيشـه الأمـة العربية

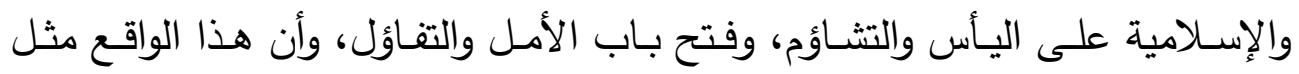

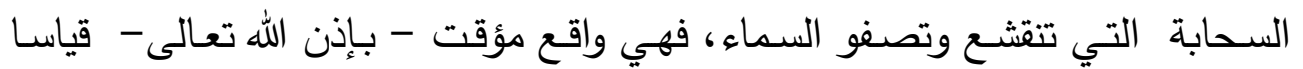

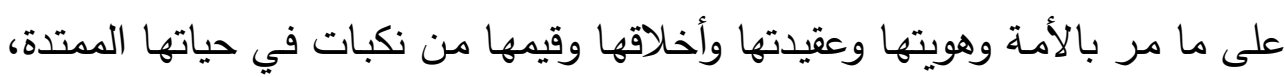

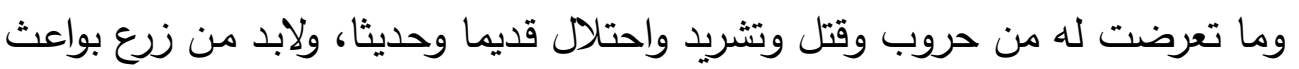

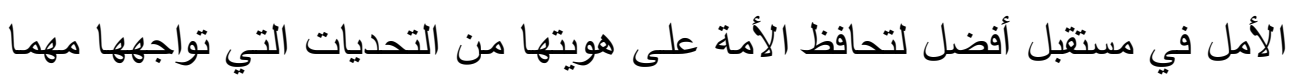
كانت قوتها.

ثانياً : التوصيات: إعادة ترتيب البيت المسلم، وتفعيل الأسرة المسلمة لتربية النشه على

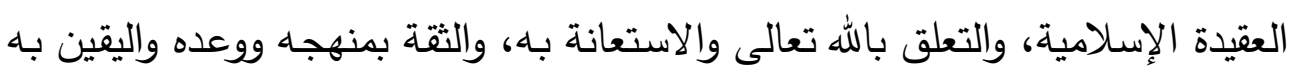
ومراقبته، والثعور بالمسئولية عن حفظ الدين من شبهات المغرضين، وأن تقوم التربية

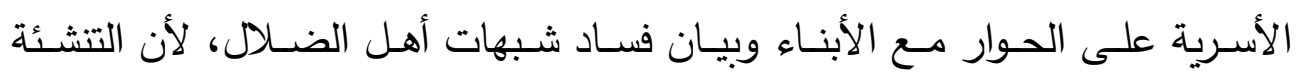

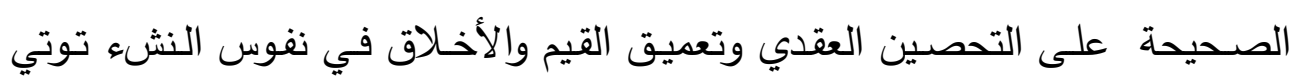
ثمرتها المرجوة.

يجب على العالم الإسـلامي أن يعيد النظر في وسائل الإعلام من (r

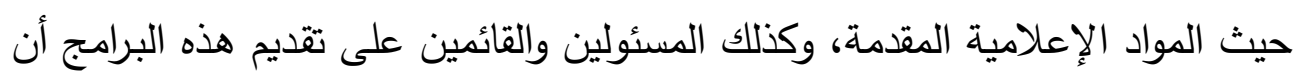

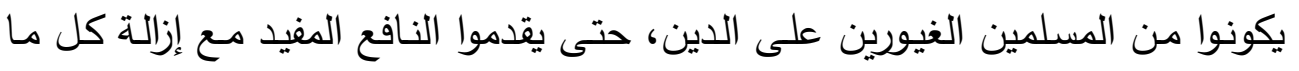

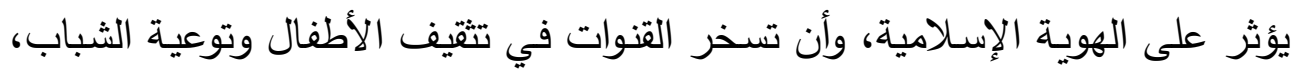
وتوجيه المجتمع لحمايته من الانحراف، والحفاظ على خصوصيته من أخطار الغزو الفكري والثقافي.

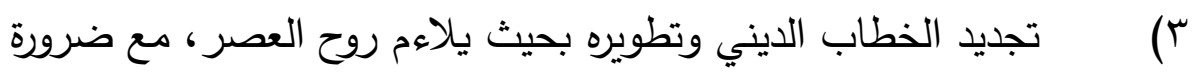
الحفاظ على أصالة الثقافة الإسلامية ومضدونها لخدمة الهوية، ودعوة الناس إلى الله 


\section{الهوية الإسلامية (روية تأصيلية في ضوء التحديات المعاصرة)}

تعالى، وعلى الأمة الإسلامية أن تطور وسائلها وأساليبها لنشر الدعوة والثقافة والهوية

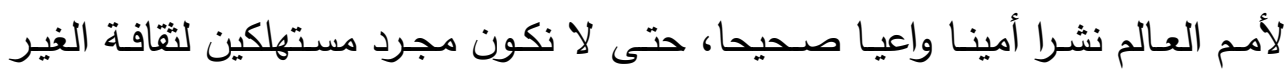

ومعلوماته، لآن الاستهلاك الثقافي يجعل المجتمع يذوب في ثنقافة وهوية الآخرين. يجب على الأمـة الإنـلامية أن تضـع الضـوابط والقيـود مـن قبل

متخصصين عن استخدام شبكة الإنترنت، خاصة بما يتعلق بالبرامج الإباحية المنافية

لقيم وثقافة وهوية المجتمعات الإسلامية للحفاظ على ديننا وأخلاقنا وثقافتنا وشبابنا.

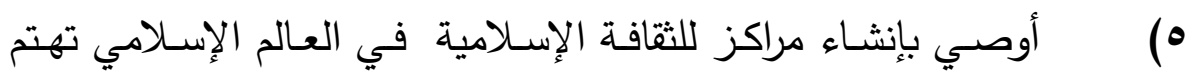

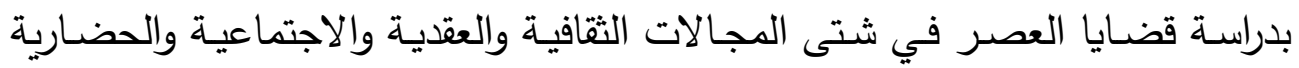

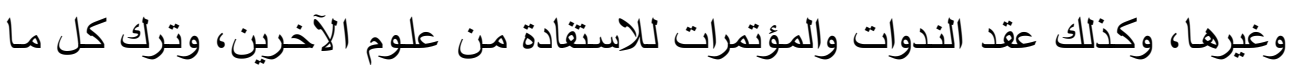
يصادم هويتنا وديننا: قال تعالى:

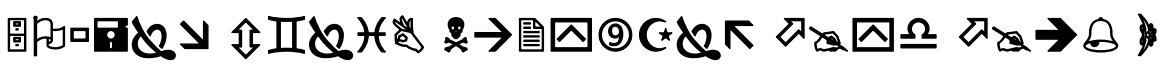

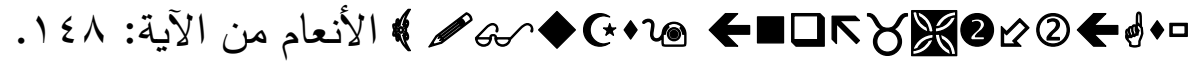
عقد مؤتمرات دولية في الثقافة الإسـامية في كلية الدعوة وأصسول

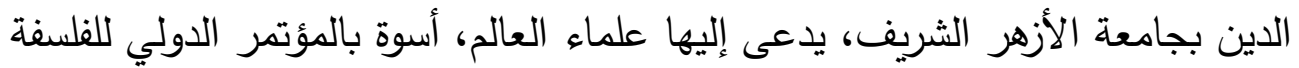

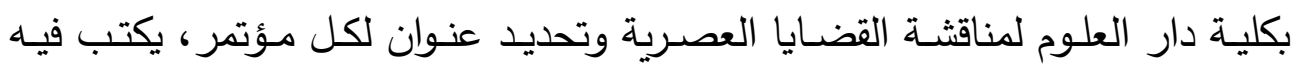

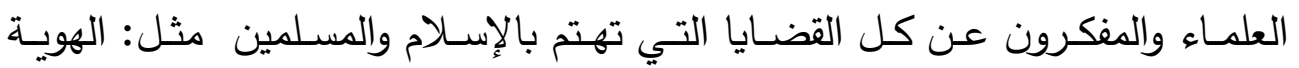
الإسلامية، وأساليب الدعوة ووسائلها وقضايا الأقليات في العالم الإسلامي، والخبات الخبرات

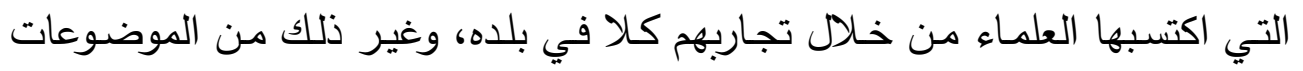

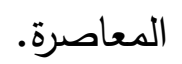

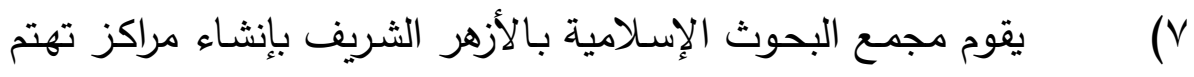

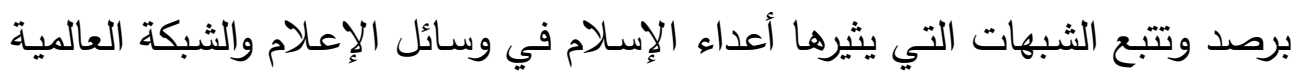

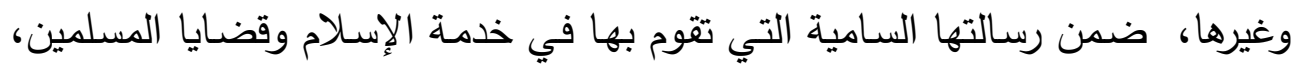
فتقوم المراكز من خلال العلماء و الدفكرين بتتبع وتسجيل هذه الافتراءات وتفنيدها 


\section{الهوية الإسلامية (روية تأصيلية في ضوء التحديات المعاصرة)}

والردود المقنعة عليها بالحجج والبراهين المنطقية، لأن إظهار هذه الأفكار الزائفة

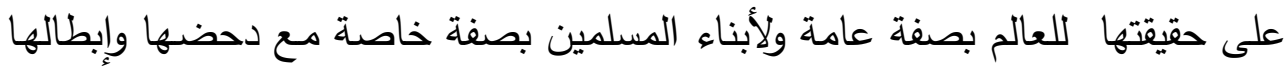
من الأولويات على علماء الأمة الإسلامية حتى لا تختلط الأمياء لألمور وتلتبس الأفكار

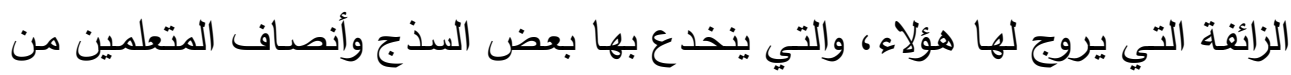

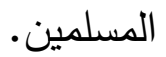

$$
\text { أهم مر اجع البحث }
$$


الهوية الإسلامية (روية تأصيلية في ضوء التحديات المعاصرة)

القرآن الكريخ

1- أجنحة المكر الثلاثة: د. عبد الرحمن حسن حبنكة، طبع دار القلم دمشق،

طبعة سادسة سنة . 99 ام.

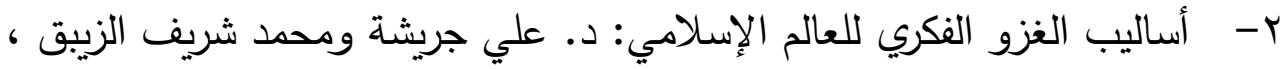

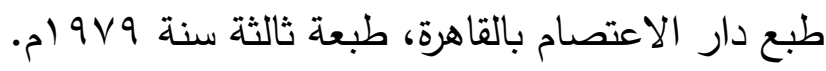
r- الإسلام في وجه التغريب - مخططات الاستشراق والتبشير: الأستاذ / أنور الجندي،طبع دار الاعتصام بالقاهرة، بدون.

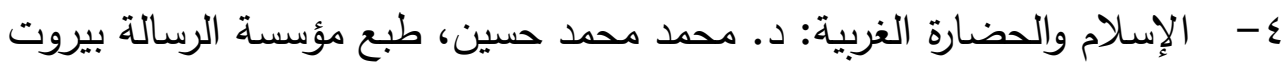

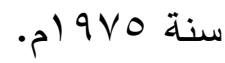

0- الإسلام والعصر الحديث: الأستاذ / وحيد الدين خان، طبع مطبعة المختار الإسلامي بالقاهرة، طبعة ثانية سنة 9VA ام.

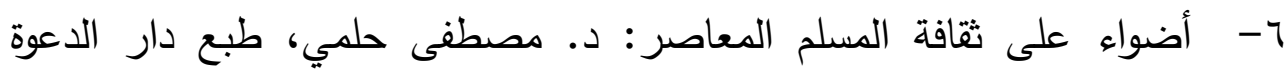

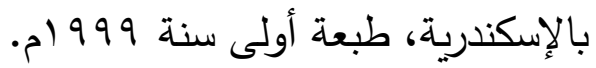

- ت تجديد الوعي الإسلامي: د. عبد الكريم بكار، طبع دار القلم دمشق، طبعة

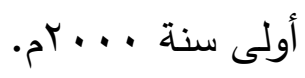

^- التعريفات: الإمام / الثريف علي بن محمد الجرجاني، طبع دار الكتب العلمية

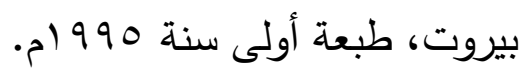

9- الثقافة العربية في عصر العولمة: الأستاذ / تركي الحمد، طبع مؤسسة الرسالة بيروت، طبعة أولى سنة بو 99 ام.

• 1- الجات والتبعية الثقافية: د. مصطفى عبد الثبد الغني، طبع الهيئة الدصرية العامة للكتاب، مكتبة الأسرة سنة 999 ام.

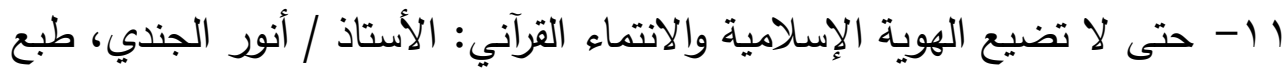
دار الاعتصام بالقاهرة، بدون. 


\section{الهوية الإسلامية (روية تأصيلية في ضوء التحديات المعاصرة)}

r ا- حصونتا مهددة من داخلها: د. محمد محمد حسين، طبع دار الرسالة للنشر والتوزيع مكة المكرمة - السعودية، طبعة الثانية عشر سنة بو9 الم. rا - خصائص التصور الإسلامي: الأستاذ / سيد قطب، طبع دار الثروق بالقاهرة، طبعة عاشرة سنة 911 (م. ع ا- دراسات إسلامية: الأستاذ / سيد قطب، طبع دار الثروق بالقاهرة، طبعة

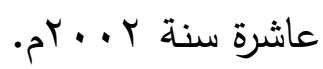
10- دلائل النبوة ومعرفة أحوال صاحب الثريعة: الإمام / أبو بكر أحمد بن الحسين

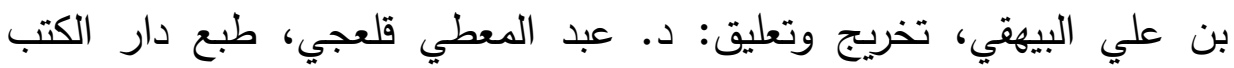
العلمية بيروت، طبعة أولى سنة 910 ام.

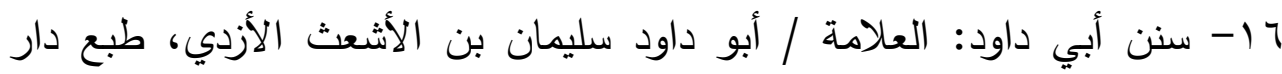

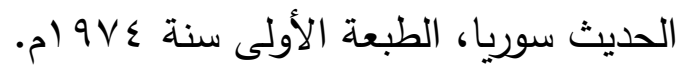

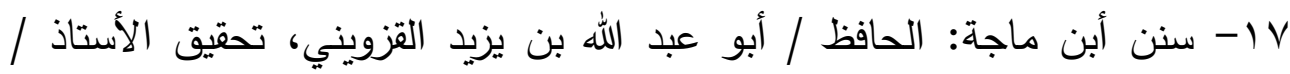

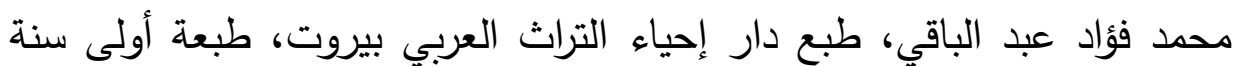
. 19 V

11 ا- سنن التردذي: الإمام الحافظ / أبو عيسى محمد بن عيسى بن سورة، تحقيق

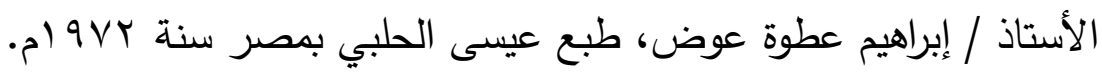
9 1- الثخصية الإسلامية دراسة قرآنية: د. عائثة عبد الرحمن (بنت الثاطئ الثئ)، طبع

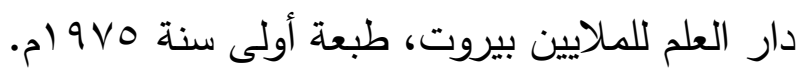

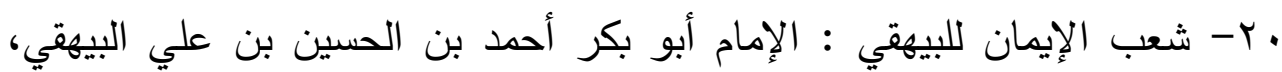

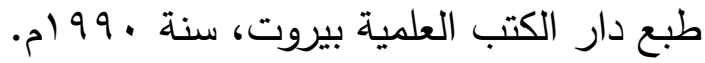

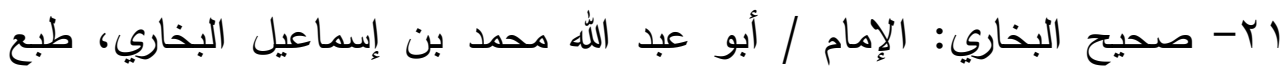

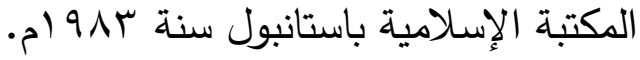

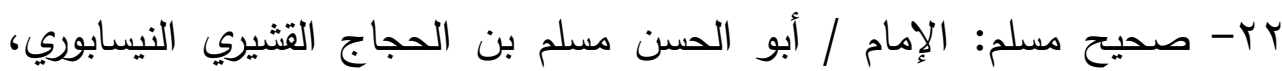




\section{الهوية الإسلامية (روية تأصيلية في ضوء التحديات المعاصرة)}

تحقيق: الأستاذ / محمد فؤاد عبد الباقي، طبع دار إحياء التراث العبي بيروت،

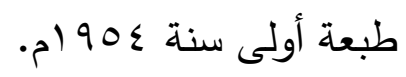

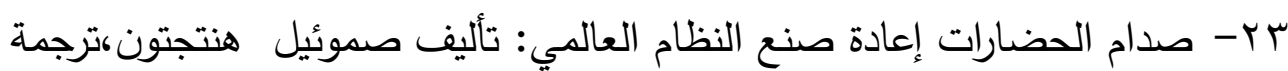

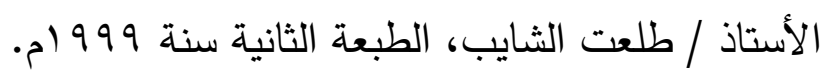

ع ז- صراع الثقافة العربية مع العولمة: د. محمد الثبيبي، طبع دار العلم للملايين

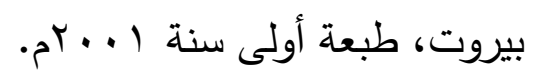

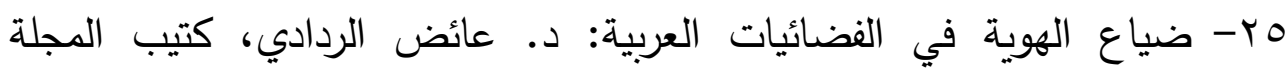

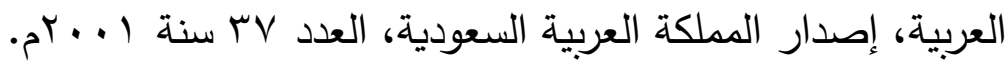

דr- العالم الإسلامي في عصر العولمة: د. عبد العزيز عثمان التويجري، طبع دار

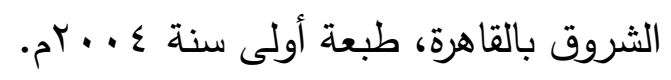

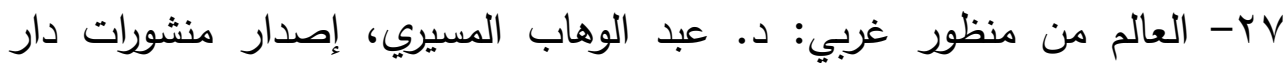

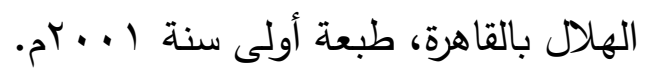

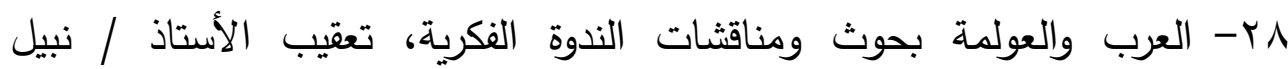

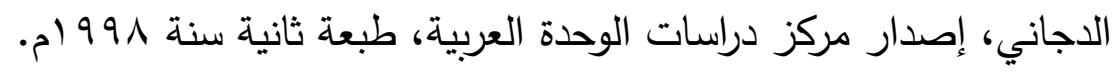

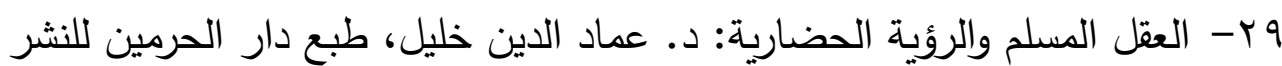

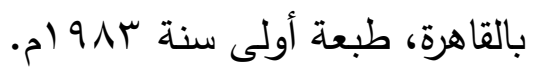

• ب- العولمة الثقافية وأثرها على الهوية: د. خالد عبد الله القاسم، جامعة الملك سعود

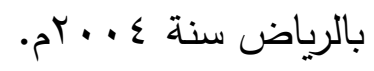

اس- العولمة وقضية الهوية الثقافية في ظل الثقافة العربية المعاصرة: الأستاذ /

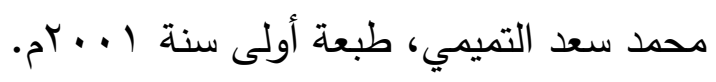

r r- الغارة على العالم الإسلامي: ا.ل شاتلية ترجمة الأستاذ / محب الدئل الدين الخطيب،

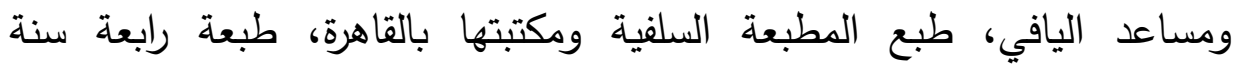




\section{الهوية الإسلامية (روية تأصيلية في ضوء التحديات المعاصرة)}

rب- الغزو الثقافي والمجتمع العربي المعاصر: د. محمد سيد محمد، طبع دار الفكر العربي بالقاهرة، طبعة أولى سنة ع 99 ام.

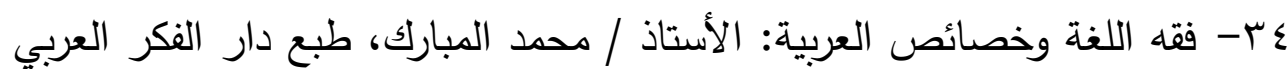

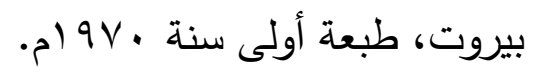

هب- في ظلال القرآن: الأستاذ / سيد قطب، طبع إنع دار الثروق بالقاهرة، الطبعة السادسة عشر سنة . 99 (م.

צr- لسان العرب: الإمام / جمال الدين بن منظور الأفريقي، طبع دار المعارف

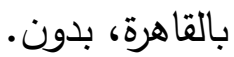

V V- ماذا خسر العالم بانحطاط المسلمين: الثيخ / أبو الحسن الندوي، طبع مكتبة الدعوة الإسلامية، الطبعة سادسة سنة 970 ام.

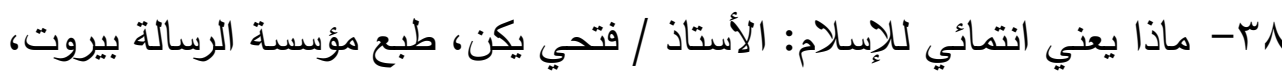

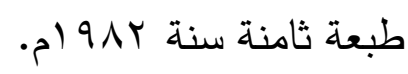
qr- مجموعة رسائل الإمام / حسن البنا، رسالة دعوتنا، طبع دار التوزيع والنشر

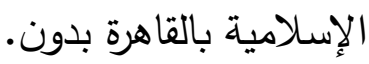

• ع- مخاطر العولمة على الهوية الثقافية: د. محمد عمارة، طبع دار نهضة مصر بالارد

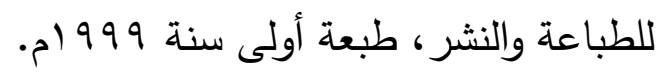

اء- المسلمون والعولمة: الأستاذ / محمد قطب، طبع دار الشروق بالقاهرة، الطبعة

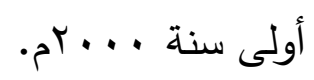

r r - مسند الإمام أحمد بن حنبل، طبع الدكتب الإسلامي بيروت بدون

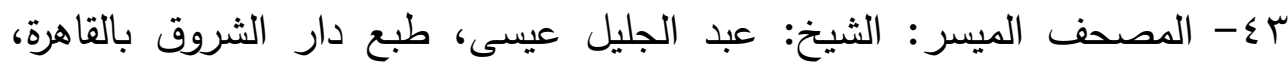

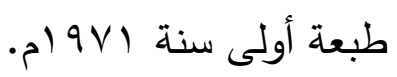
؟ ؟- معالم الشخصية الإسلامية: د. عمر سليمان الأشقر، طبع دار النفائس للنشر المر والتوزيع الأردن، الطبعة سابعة سنة ل... بام. 


\section{الهوية الإسلامية (روية تأصيلية في ضوء التحديات المعاصرة)}

0ء- مقدمة ابن خلدون، طبع المكتبة التجارية بصصر ، بدون

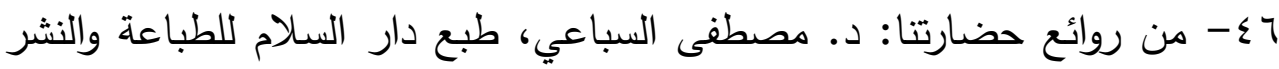

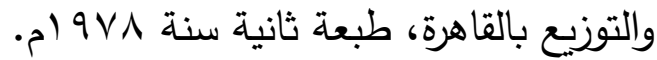

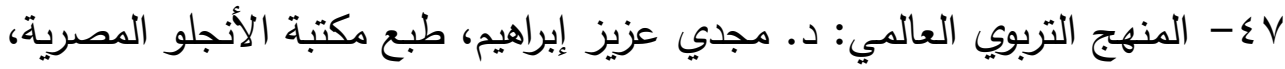

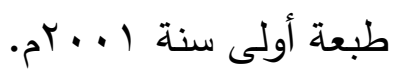

1ـ - الموسوعة الفلسفية العربية، طبح معهد النماء العربي بيروت سنة 990 (م. 9؟- نحن والعولمة من يربي الآخر : د. سعد البزغي، سلسلة كتاب المعرفة، العدد

$$
\text { السابع، طبعة أولى سنة } 999 \text { (ام. }
$$

كتاب المؤتمر الدولي الرابع للفلسفة الإسلامية، الإسلام في عصر العولمة، كلية دار العلوم،جامعة القاهرة سنة 999 ام.

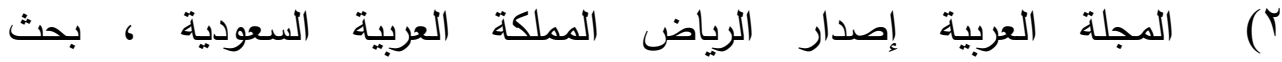

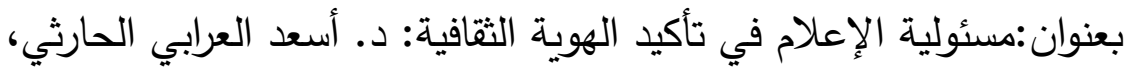
r السيطرة: الأستاذ / خالد أبو الفتوح.

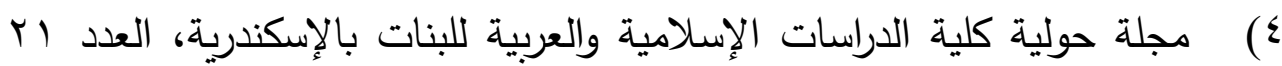

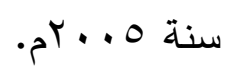

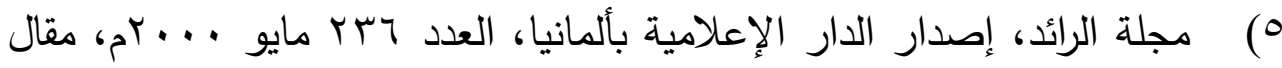

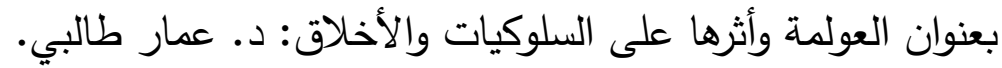

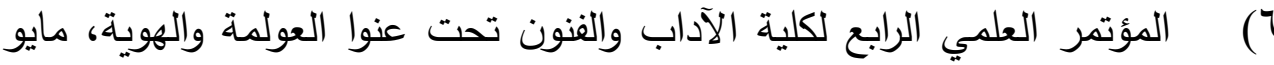
1991 ام، بحث بعنوان: الثقافة العربية بين العولمة والخصوصية: د. حسن الادن حنفي، منشورات جامعة فيلادلفيا سنة 999 ام.

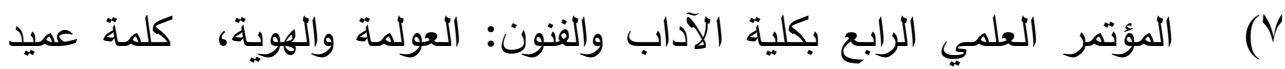




\section{الهوية الإسلامية (روية تأصيلية في ضوء التحديات المعاصرة)}

الكلية: د. صالح أبو ضلع، منشور جامعة فيلادلفيا، طبعة أولى سنة 999 ام.

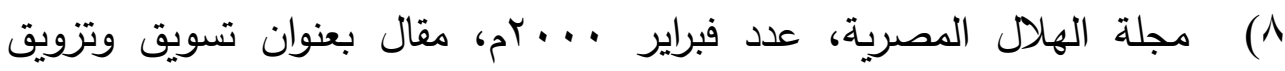
العولمة، مراجعة نقدية لكتاب توماس فريدمان: د. محمد عبد الفضيل،إصدار دار

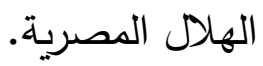
مواقع شبكة المعلومات العالمية - النت:

أثر العولمة على الهوية: الأستاذ / محمد صديق، مقال منشور على شبكة

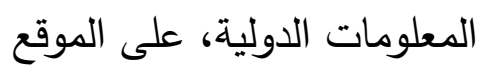

http//www.shareah.com/hdex.php?/records/list/id/1/

أهمية التعليم في الحفاظ على الهوية الإسلامية: الأستاذ / بدر ناصر البدر،

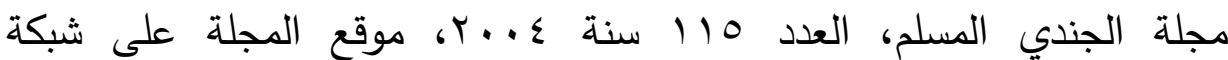
المعلومات الدولية www.gmuslimnaseed.com.

حراسة الهوية في ظل التغريب، بحث منشور على شبكة المعلومات الدولية على الموقع حوار مع د. عفاف مختار منشور على شبكة المعلومات الدولية.

خصائص الهوية الإسلامية: د. أحمد عمر هاشم، مقال منقول من جريدة

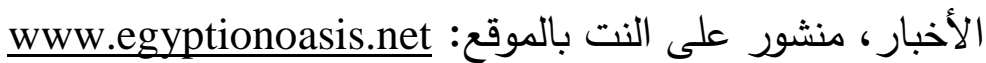

صدام الحضارات: د. جعفر شيخ إدريس، مقال في موقعه على شبكة

www.gafarisis.com المعلومات الدولية

صراع الهويات وخصائص الهوية الإسلامية، مقال منشور على موقع الثبكة

$$
\text { الإسلامية }
$$

www.islamweb.ket/media/index.php?bagarticle\&lang=a\&id=63232 العولمة وأثرها على الهوية: د. خالد عبد الله القاسمهمال منشور على موقع 
الهوية الإسلامية (روئة تأصيلية في ضوء التحديات المعاصرة)

الإسلام اليوم www.islamtoday.net/pohoothiartshaw/86/73350

مجلة البيان اللبنانية: د. محمد إسماعيل الدقدم، موقع المجلة على الثبكة

العالمية www.albayan.magazine.com/dialagues?/0/0ht

(·) هل الهوية في خطر، الأستاذ / خباب مراد الحمد، بحث منشور في موقع

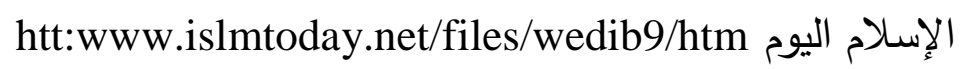

(1) الهوية الإسلامية والمؤامرة عليها: د. ناصر دسوقي رمضان، مقال منشور على الإنى

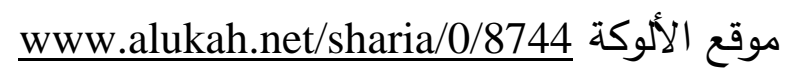

(Y ( ) الهوية بين الجوهري والمضاف، بحث منشور في صحفية الوطن العمانية في

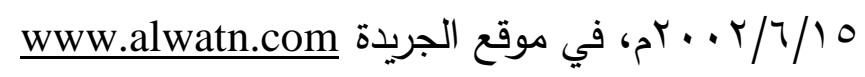


الهوية الإسلامية (روية تأصيلية في ضوء التحديات المعاصرة)

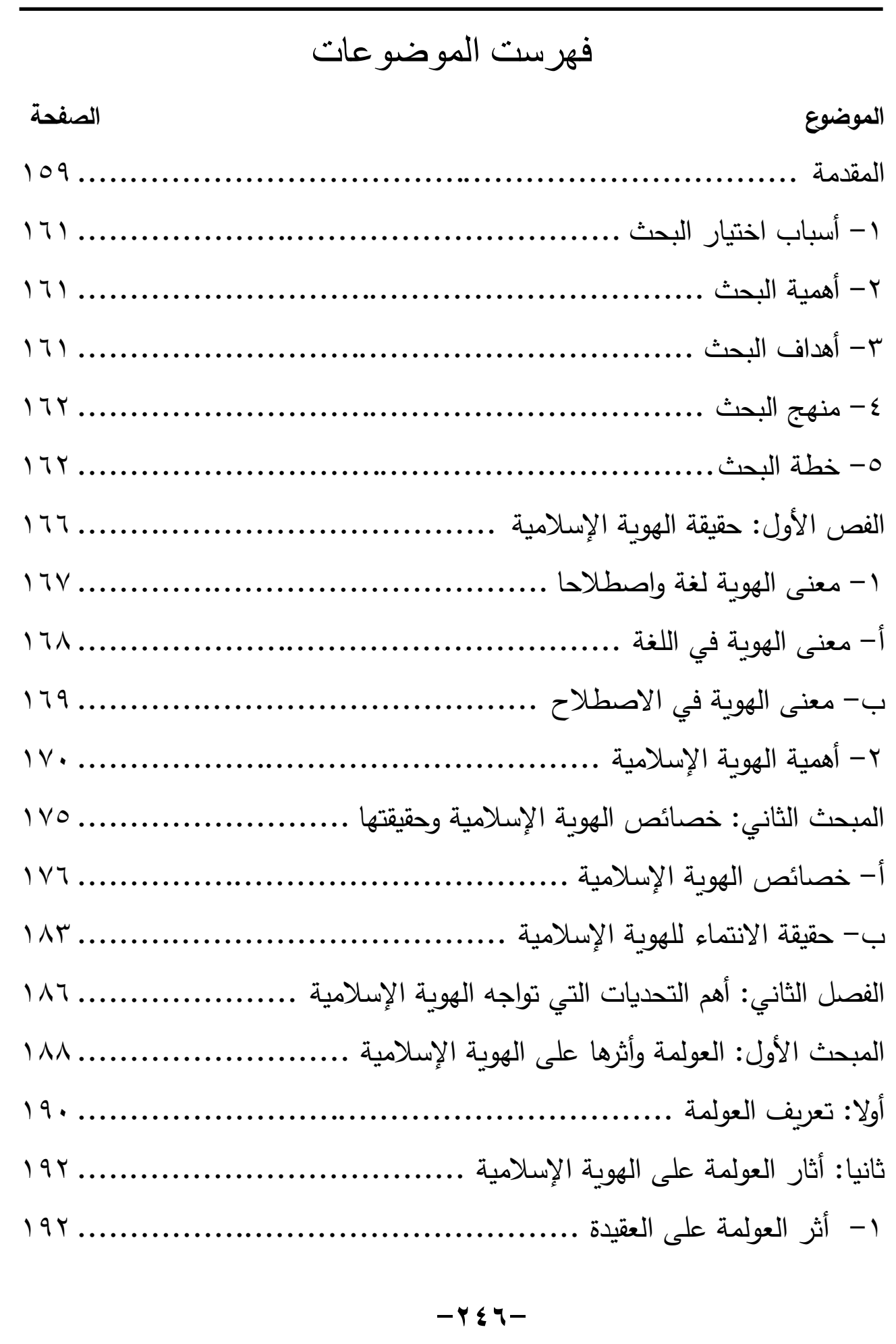


الهوية الإسلامية (روية تأصيلية في ضوء التحديات المعاصرة)

194 r- أثر العولمة على الأخلاق

195 ب- أثر العولمة على البث الإعلامي

$19 \leq$ ع- أثر العولمة على اللغة العربية

190 0- أثر العولمة على الكيان الأسري .

ثالثا: كيف نواجه آثار العولمة على الهوية الإسلامية في العصر الحاضر ..... رابعا: نماذج واقعية لسلبيات العولمة على الهوية الإسلامية .............................

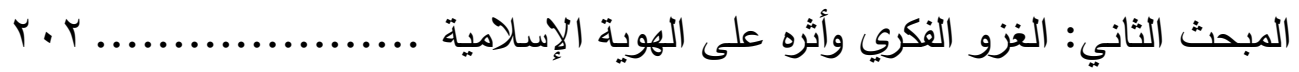
الفصل الثالث: مسئولية الأمة الإسلامية في الحفاظ على الهوية في العصر الحاضر 9 . المبحث الأول: دور المؤسسات الدعوية والاجتماعية لترسيخ الهوية في قلوب

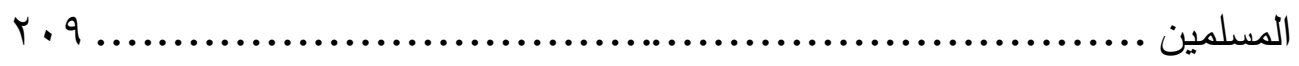
أولا: مسئولية العلماء والدعاة في حماية الهوية وتدعيمها في نفوس المدعوين .. · آ

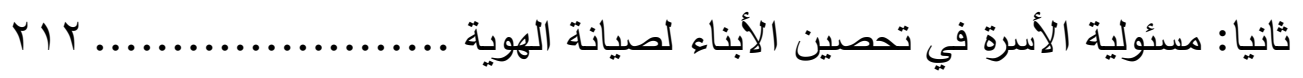
ثالثا: دور المؤسسات التربوية في الحفاظ على الهوية لدى الأجيال المعاصرة ... باץ رابعا: مسئولية الحكام والولاة في الحفاظ على هوية الأمة .............................

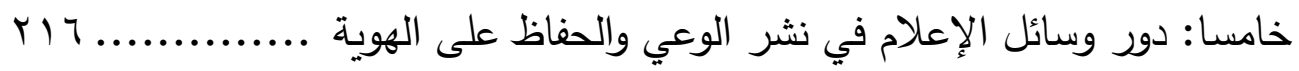
المبحث الثاني: الهوية الإسلامية في ضوء التحديات المعاصرة ................... 9 1 1- الهوية بين تهاون العالم الإسلامي وحفاظ الغرب ............................. r- أساليب طمس الهوية الإسلامية .............................................. r- ثمار تمسك العالم الإسلامي بالهوية في العصر الحاضر ......................

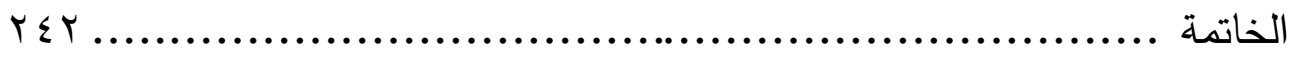
$r \leqslant V$ أهم المراجع . 
الهوية الإسلامية (روية تأصيلية في ضوء التحديات المعاصرة)

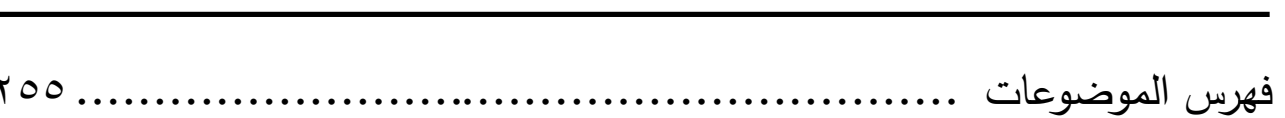

تم بحمد الله تعالى ونوفيقه 